\title{
ANÁLISE DO PAPEL DO SISTEMA COMPLEMENTO NA INJÚRIA A CÉLULAS RENAIS CAUSADA PELO VENENO \\ DA ARANHA Loxosceles
}

Tese apresentada ao Programa de PósGraduação Interunidades em Biotecnologia USP/Instituto Butantan/IPT, para obtenção do Título de Doutor em Biotecnologia. 


\section{ANÁLISE DO PAPEL DO SISTEMA COMPLEMENTO NA INJÚRIA A CÉLULAS RENAIS CAUSADA PELO VENENO DA ARANHA Loxosceles}

Tese apresentada ao Programa de PósGraduação Interunidades em Biotecnologia USP/Instituto Butantan/IPT, para obtenção do Título de Doutor em Biotecnologia. Área de concentração: Biotecnologia Orientador: Prof. Dra. Denise V. Tambourgi Versão original 
DADOS DE CATALOGAÇÃO NA PUBLICAÇÃO (CIP)

Serviço de Biblioteca e Informação Biomédica do

Instituto de Ciências Biomédicas da Universidade de São Paulo

reprodução não autorizada pelo autor

Okamoto, Cinthya Kimori.

Análise do papel do Sistema Complemento na injúria a células renais causadas pelo veneno da aranha Loxosceles I Cinthya Kimori Okamoto. -- São Paulo, 2012.

Orientador: Prof ${ }^{a}$ Dra. Denise Vilarinho Tambourgi.

Tese (Doutorado) - Universidade de São Paulo. Instituto de Ciências Biomédicas. Programa de Pós-Graduação Interunidades em Biotecnologia USP/IPT/Instituto Butantan. Área de concentração: Biotecnologia. Linha de pesquisa: Ação de venenos e toxinas animais sobre o Sistema Complemento.

Versão do título para o inglês: Analysis of the Complement System in the injury of kidney cells caused by Loxosceles spider venom.

Descritores: 1. Veneno 2. Loxosceles intermedia 3. Células renais 4. Esfingomielinase D 5. Sistema Complemento 6. Metaloproteases I. Tambourgi, Profa Dra. Denise Vilarinho II. Universidade de São Paulo. Instituto de Ciências Biomédicas. Programa de Pós-Graduação Interunidades em Biotecnologia USP/IPT/Instituto Butantan III. Título. 
Candidato(a)

Cinthya Kimori Okamoto.

Título da Tese:

Análise do papel do Sistema Complemento na injúria a células renais causadas pelo veneno da aranha Loxosceles.

Orientador(a): $\quad$ Prof $^{\mathrm{a}}$ Dra. Denise Vilarinho Tambourgi.

A Comissão Julgadora dos trabalhos de Defesa da Tese de Doutorado, em sessão pública realizada a I................................, considerou

\section{( ) Aprovado(a) ( ) Reprovado(a)}

$\begin{array}{ll}\text { Examinador(a): } & \text { Assinatura: } \\ & \text { Nome: ........ } \\ & \text { Instituição: } \\ \text { Examinador(a): } & \text { Assinatura: } \\ & \text { Nome: ....... } \\ & \text { Instituição: } \\ \text { Examinador(a): } & \text { Assinatura: } \\ & \text { Nome: ........ } \\ & \text { Instituição: } \\ \text { Examinador(a): } & \text { Assinatura: } \\ & \text { Nome: ....... } \\ & \text { Instituição: } \\ & \text { Assinatura: } \\ \text { Presidente: } & \text { Nome: .......... } \\ & \text { Instituição: }\end{array}$


À minha mãe Fumie, meu irmão Daniel e familiares, pelo incentivo, apoio e dedicação nesta longa, agradável e vencida jornada. 


\section{AGRADECIMENTOS}

"Agradeço todas as dificuldades que enfrentei; não fosse por elas, eu não teria saído do lugar. As facilidades nos impedem de caminhar. Mesmo as críticas, nos auxiliam muito"

Chico Xavier

Enfim, chegamos ao ponto final desta história (será mesmo?), ou parte dela. Foram cinco anos de muitos obstáculos e dificuldades, mas também de muita felicidade, ótimos resultados e bons momentos que passei durante esta "estadia". Este trabalho foi fruto de muito esforço, dedicação e amor. É uma alegria imensa que sinto ao ver que estes resultados possam contribuir para a aprendizagem e construção do conhecimento pessoal e científico.

Muito obrigada às pessoas que participaram nesta grandiosa fase da minha vida. Sou o resultado do amor, compreensão e apoio de cada um de vocês. Desde já peço desculpas por não agradecer e, de certa forma, homenagear aquelas que participaram nesta tese da forma que merecem; gostaria de expressar a minha gratidão a todos individualmente, porém ficaria maior que o trabalho. Todo o respeito, carinho e amizade que tiveram por mim, assim espero ter retribuído da melhor forma possível.

Primeiramente, agradeço à minha orientadora Dra Denise Vilarinho Tambourgi por abrir as portas do Laboratório, pela confiança, dedicação, oportunidade, incentivo, conhecimento, "puxões de orelhas" e carinho que permitiu o meu crescimento profissional e pessoal. Tenho muito admiração pelo amor que sente na sua vida científica e isso nos contagia de uma forma bastante positiva que levaremos para as nossas vidas. Sinto muito orgulho por ser sua aluna!

À Dra Rute Maria Gonçalves de Andrade pela grande colaboração e dedicação; sem sua contribuição este trabalho não poderia ser realizado!

À Dra Carmen W. van den Berg, da Universidade de Cardiff, Reino Unido, pela colaboração e conhecimento.

Ao Dr Jorge Mário da Costa Ferreira Jr. pela disponibilidade, muitas e longas leituras no citômetro de fluxo, resultados imprescindíveis para o trabalho. 
Aos pesquisadores doutores do Laboratório de Imunoquímica Carla Squaiella, Fernanda Calheta Vieira Portaro, Osvaldo Augusto Esteves Brazil Sant'Anna e Wilmar Dias da Silva. Muito obrigada pela atenção e pelos ensinamentos!

Ao pesquisador Fábio Carlos Magnoli pela amizade e companherismo, obrigada por ter me esperado tantos dias quando ficava até altas horas no laboratório.

Aos funcionários do Laboratório de Imunoquímica Alécio Barbosa Rodrigues, Ana Cláudia Santana, Ana Freire, Carolina Pereira Liauw Rodrigues, Márcia Franco, Maura Coração Ferreira, Ricardo Eiji Noguti, Severino Ramos da Silva e aos ex-funcionários que também participaram: João Batista Coelho, José Cassiano Borba e Sílvia Aparecida Camargo. Agradeço a todos pela grande ajuda, amizade, apoio e agradável convivência.

Aos ex-alunos e pós-doutoranda Dra Danielle Paixão Cavalcante, Dr Matheus de Freitas Fernandes-Pedrosa e Dra Sônia Aparecida de Andrade Chudzinki. Agradeço pelo incentivo, paciência e por passar todo o conhecimento prático e teórico.

Aos amigos do Laboratório de Imunoquímica Alexandre Kazuo Kuniyoshi, Ângela Alice Amadeu, Bárbara Cortopassi Fonseca, Daniela Cajado, Dr Emerson José Venancio, Estevam José Baldon, Luciana Vieira Carvalho, Rafaela Marino Lafraia e Rosana de Fátima Shoji. Muito obrigada pelas boas risadas, pelo apoio e amizade!

Às amigas Dra Giselle Pidde Queiroz, Isadora Maria Vilas Boas e Priscila Hess Lopes. Agradeço pelo apoio, ajuda, amizade e credibilidade. Vocês são pessoas muito especiais que guardarei pelo resto na minha vida.

À “Turma do curi” Cássia Regina Pichiteli, Daniela Tiemi Myamoto, Elaine Rodrigues, Felipe Raimondi Guidolin, Gabriela Dicieri Tanaka, Karina Scaramuzzi, Lia Aguiar e Mara Adriana Correa. Além de amigos são pessoas, que ao longo dos anos de convivência, pude ter a certeza de que fazem parte da minha família. Muito obrigada por serem ótimos ouvintes, pelo apoio, bons conselhos, carinho, pelas boas risadas, incentivo e por vários "happy hours" de descontração. 
Ao Guilherme Hiromi Yoshikawa agradeço pelo carinho, incentivo e compreensão. Faz parte tanto da minha vida profissional quanto pessoal, esteve sempre presente em momentos tristes e felizes, e por isso se torna para mim uma pessoa muito especial. Muito obrigada!

A José Roberto Marcelino, Patrícia Zorzete, Ana Cristina Lustoza da Luz e a todos que fazem parte da Divisão Bioindustrial do Instituto Butantan, Seção de Plasmas Hiperimunes. Agradeço pela dedicação, incentivo, apoio e compreensão.

À Dra Ana Marisa Chudzinski Tavassi, Dr José Alexandre Marzagão Barbuto e Dr Niels Olsen Saraiva Câmara por participarem da minha banca do exame de qualificação, além de contribuírem ao estudo.

Ao Programa de Pós-Graduação Interunidades em Biotecnologia USP/IPT/I.Butantan pela minha formação profissional.

À FAPESP e CNPq pelo incentivo e apoio financeiro.

Por fim, e não o menos importante, à toda a minha família e amigos que não citei. Agradeço a todos de coração pela dedicação, amor e compreensão. Com certeza sem eles não viveria! 
“O ser humano não pode deixar de cometer erros; é com os erros, que os homens de bom senso aprendem a sabedoria para o futuro." 


\section{RESUMO}

OKAMOTO, C. K. Análise do papel do Sistema Complemento na injúria a células renais causada pelo veneno da aranha Loxosceles. 2012. 107f. Tese (Doutorado em Biotecnologia) - Instituto de Ciências Biomédicas da Universidade de São Paulo, São Paulo, 2012.

O envenenamento por aranhas Loxosceles pode resultar em dois tipos de manifestações clínicas: o loxoscelismo cutâneo e o sistêmico. Hemólise, agregação plaquetária, inflamação persistente, falência renal e morte podem ser observadas em pacientes com manifestações sistêmicas. Apesar da pouca incidência de vítimas com falência renal, esta é a principal causa de óbito, ocorrendo principalmente em crianças. O principal fator do veneno da aranha Loxosceles, responsável pelas manifestações locais e sistêmicas, é a esfingomielinase D (SMase D). O presente estudo teve como objetivo investigar a ação tóxica do veneno de $L$. intermedia e da SMase D sobre células renais humanas, bem como o possível envolvimento de metaloproteases endógenas e do Sistema Complemento nesse processo. Os resultados obtidos mostram que tanto o veneno como a SMase D, foram capazes de causar morte celular, possivelmente associada à ativação de metaloproteases de matriz extracelular, MMP-2 e MMP-9, e por ativação do Sistema Complemento após clivagem de MCP por metaloproteases da família das adamlisinas. A expressão de outros reguladores do Complemento, como DAF e CD59, não foi afetada pelo tratamento. A remoção de $\mathrm{MCP}$ permitiu a ativação do Complemento, como determinado pelo aumento da deposição de componentes envolvidos na ativação do sistema (C3, C4, properdina, CRP) e pelo aumento da morte celular. Também foi observado incremento na deposição do fator $\mathrm{H}$, mas não de $\mathrm{C} 4 \mathrm{bp}$, após a tratamento das células com veneno/SMase D. Diminuição na expressão das moléculas de superfície como MHC-I, $\beta 2$ microglobulina, EPCR e EGFR, foi observada e relacionada à ativação de metaloproteases da família das adamlisinas. Em conjunto, tais resultados mostram que o veneno e a SMase D de aranhas Loxosceles induzem aumento na expressão/ativação de metaloproteases endógenas, operantes nos eventos de morte celular por apoptose e necrose, os quais podem ter um papel relevante para os danos renais presentes no loxoscelismo sistêmico humano.

Palavras-chave: Loxosceles intermedia. Loxoscelismo sistêmico. Células renais. Veneno. Esfingomielinase D. Sistema Complemento. Metaloproteases. 


\begin{abstract}
OKAMOTO, C. K. Analysis of the Complement System in the injury of kidney cells caused by Loxosceles spider venom. 2012. 107 p. PhD thesis (Biotechnology) - Instituto de Ciências Biomédicas da Universidade de São Paulo, São Paulo, 2012.

Envenomation by Loxosceles spider can result in two forms of clinical manifestations: the cutaneous and the systemic loxoscelism. Haemolysis, platelet aggregation, persistent inflammation, renal failure and death can be observed in patients with systemic manifestations. Despite the low incidence of renal failure victims, this is the main cause of death, occurring mainly in children. The sphingomyelinase D (SMase D) is the main factor in Loxosceles spider venom responsible for local and systemic manifestations. This study aimed to investigate the toxicity of the L. intermedia venom and SMase D on human kidney cells and the possible involvement of endogenous metalloproteinases and Complement system in this process. Results showed that the venom and the SMase D were able to cause cell death, possibly associated with the activation of extracellular matrix metalloproteases, MMP-2 and MMP-9, and the action of Complement system after MCP cleavage by metalloproteases of the adamlisins family. The expression of other Complement regulators, such as DAF and CD59, was not affected by the treatment. The removal of MCP allowed activation of Complement, as determined by the increase of the deposition of components involved in the system activation (C3, C4, properdin and CRP) and cell death. It was also observed an increase in the deposition of factor $\mathrm{H}$, but not of $\mathrm{C} 4 \mathrm{bp}$, after treatment of cells with venom/ SMase $\mathrm{D}$. Decrease in the expression of surface molecules such as MHC-I, $\beta 2$ microglobulin, EPCR and EGFR was observed and related to the activation of metalloproteinases from the adamlisins family. Together, theses results show that the venom and the SMase D induce increased expression/ activation of endogenous metalloproteases, possibly operating in the cell death events by apoptosis and necrosis, which may have an important role for the kidney injury present in the human systemic loxoscelism.
\end{abstract}

Key words: Loxosceles intermedia. Systemic loxoscelism. Kidney cells. Venom. Sphingomyelinase D. Complement System. Metalloproteases. 


\section{LISTA DE ILUSTRAÇÕES}

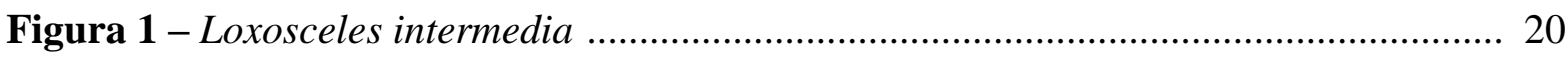

Figura 2 - Notificação Anual de Acidentes por Loxosceles no Brasil (2001 - 2011) ....... 21

Figura 3 - Ilustração representativa do rim .............................................................. 27

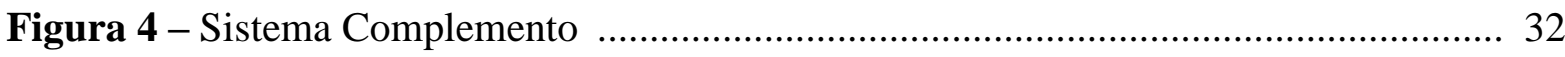

Figura 5 - Purificação da SMase D P1 …............................................................... 45

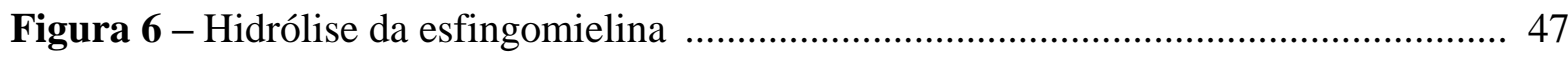

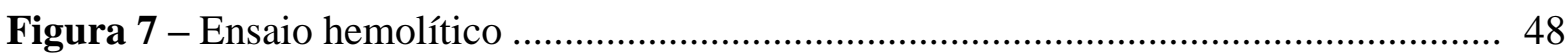

Figura 8 - Viabilidade das células HK-2 tratadas com veneno ou toxina recombinante P1

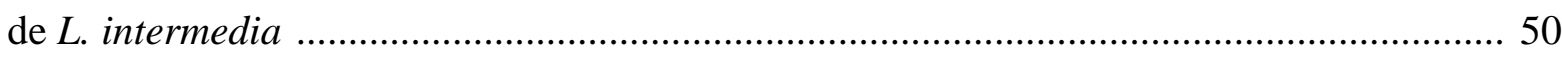

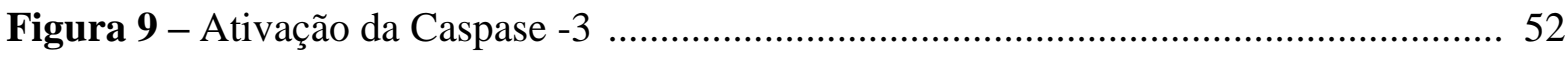

Figura 10 - Indução da expressão/secreção de gelatinases em células HK-2 pelo veneno

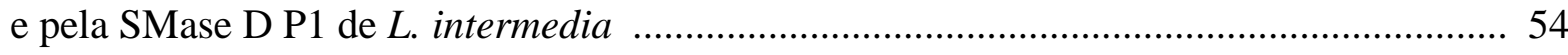

Figura 11 - Efeito tóxico da tetraciclina sobre a viabilidade das células HK-2 ................ 56

Figura 12 - Ação da tetraciclina no controle da morte celular e atividade gelatinolítica

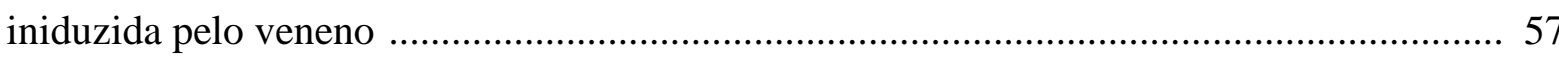

Figura 13 - Ação da tetraciclina no controle da morte celular e atividade gelatinolítica

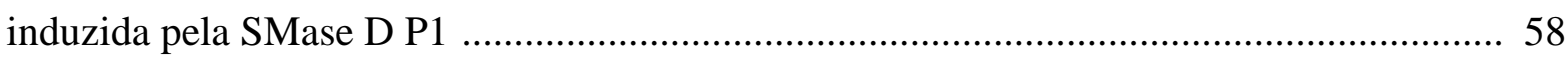

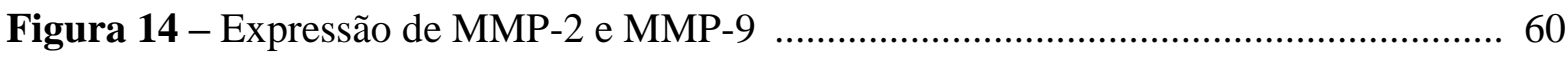

Figura 15 - Análise densitométrica da expressão de MMP-2 e MMP-9 ........................... 61

Figura 16 - Efeito do veneno e da SMase D P1 de L. intermedia sobre a expressão de moléculas de membrana, me células renais

Figura 17 - Efeito do veneno e da SMase D P1 de L. intermedia sobre a expressão de reguladores do Complemento em células renais ............................................................. 65

Figura 18 - Morte celular por Complemento ............................................................... 67

Figura 19 - Análise da deposição de componentes do Complemento na superfície das células renais

Figura 20 - Ligação das SMases D às células renais ....................................................... 71

Figura 21 - Efeito da tetraciclina e da galardina na expressão de EGFR em células renais 
Figura 22 - Efeito da tetraciclina e da galardina na expressão de EPCR em células renais 74

Figura 23 - Efeito dos inibidores de proteases na clivagem de MCP em células HK-2 induzida pelo veneno de L. intermedia 76

Figura 24 - Efeito dos inibidores de proteases na clivagem de MCP em células renais HK-2, induzida pela SMase D P1 de L. intermedia 77

Figura 25 - Clivagem de MCP nas células renais induzida pelo veneno e pela SMase D P1 de L. intermedia 78

Figura 26 - Inibição da morte celular mediada por Complemento, por galardina 79

Figura 27 - Efeito dos inibidores de ADAM 10 e ADAM 17 sobre a morte celular 81

Figura 28 - Efeito dos inibidores de ADAM 10 e ADAM 17 na expressão de moléculas de membrana das células renais 


\section{LISTA DE ABREVIATURAS}

BCIP - 5-bromo-4-chloro-3'-indolyphosphate p-toluidine salt

$\beta 2 \mathrm{~m}$ - beta 2-microglobulina

BSA - Albumina de soro bovino

C4bp - Proteína ligadora de C4b

CR1 (CD35) - Complement Receptor Type I

$\mathrm{CRP}$ - Proteína $\mathrm{C}$ reativa

$\mathrm{C} 1 \mathrm{INH}$ - Inibidor do componente C1

DAF (CD55) - Decay-acceleratting factor

DMEM - Dulbecco's Modified Eagle Medium

DMSO - dimetilsulfóxido

DNA - ácido desoxirribonucléico

2YT - SOB Terrific Broth YENB

EGFR - Receptor do Fator de Crescimento Epidermal

EPCR - Receptor endothelial da proteina C

FACS - Fluorescence-activated cell sorting

$\mathrm{fB}-$ Fator B

$\mathrm{fD}-$ Fator D

$\mathrm{fH}-$ Fator $\mathrm{H}$

fI - Fator I

FITC - Isoticianato de fluresceína

h - hora

HK-2 - Human kidney cells-2

IPTG - isopropyl- $\beta$-D thiogalactopyranoside

MAC - Complexo de ataque à membrana

MASP - Serino-protease associada à MBL

MBL - Lectina ligante de manose

MCP (CD46) - Proteína cofator de membrana

MHCI - Complexo principal de histocompatibilidade classe 1

min - minuto

MMP-2 - metaloprotease de matriz extracelular-2

MMP-9 - metaloprotease de matriz extracelular-9 
MTT - 3-(4,5-dimethylthiazol-2-yl)-2,5-diphenyltetrazolium bromide $\mu 1$ - microlitro

$\mu \mathrm{m}$ - micrograma

$\mu \mathrm{M}-$ micromolar

NBT - nitro-blue tetrazolium chloride

nm - nanômetro

PCR - Polymerase chain reaction

RNA - Ácido ribonucléico

RT-PCR - Reverse transcription polymerase chain reaction

rpm - rotações por minuto

SAP - Proteína do soro amilóide

SMase D - Esfingomielinase D

SDS - dodecil sulfato de sódio

SDS-PAGE - Eletroforese em gel de poliacrilamida com SDS

SFB - soro fetal bovino

SHN - Soro humano normal

$\mathrm{SHi}$ - Soro humano inativado

$\mathrm{VBS}^{++}$- tampão veronal

v/v - volume/volume 


\section{SUMÁRIO}

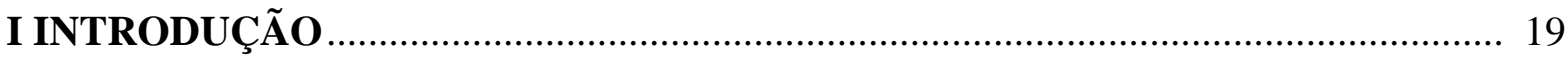

1.1 Biologia do gênero Loxosceles ……………………........................................ 19

1.2 Veneno e loxoscelismo …………………………............................................. 21

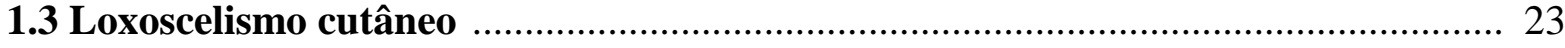

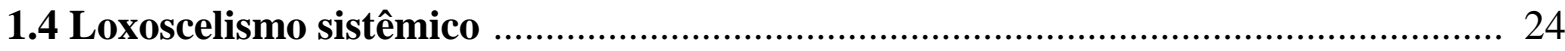

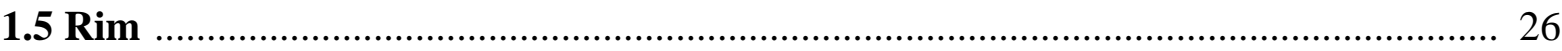

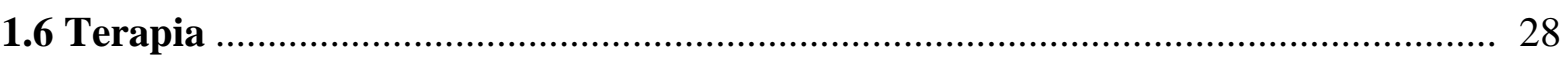

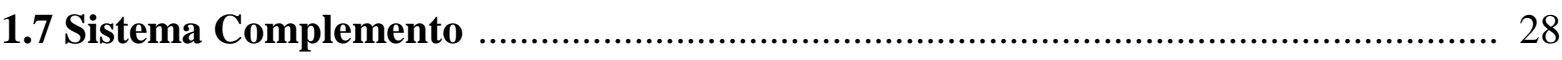

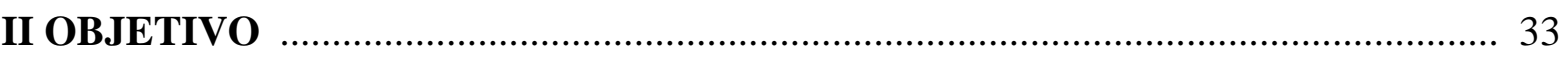

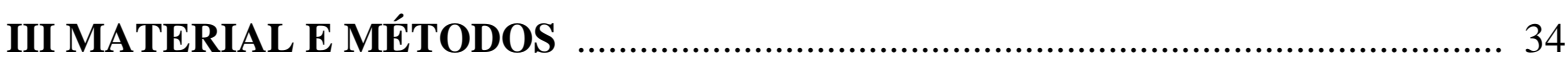

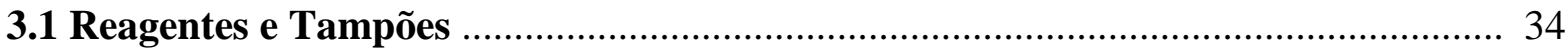

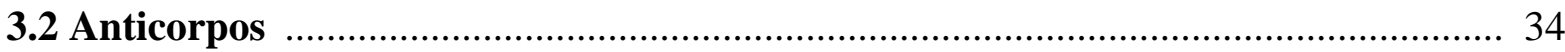

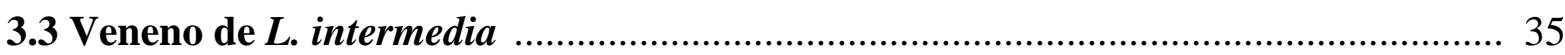

3.4 Expressão e purificação da proteína recombinante ……………………………..... 35

3.5 Análise das amostras da proteína recombinante $\mathbf{P 1}$............................................. 36

3.5.1 Eletroforese em gel de SDS-PAGE ................................................................. 36

3.5.2 Atividade esfingomielinásica ………………………………………………….... 36

3.5.3 Eritrócitos e soro humano normal ................................................................... 37

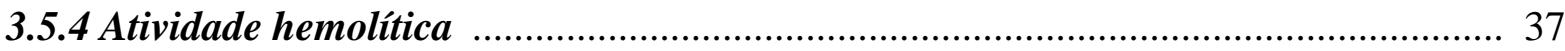

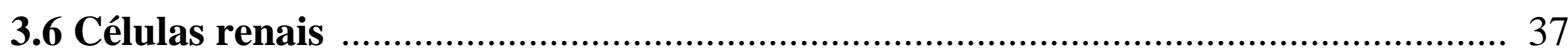

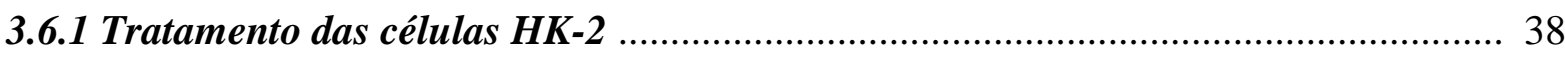

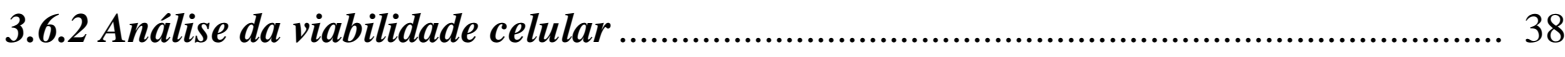

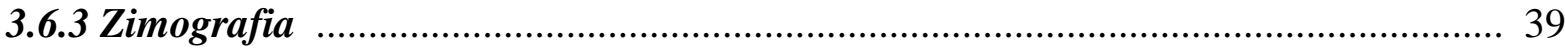

3.6.4 Extração de RNA ………………………………………………………..... 39

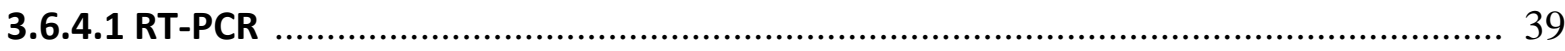

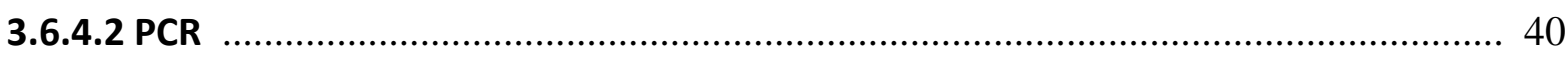

3.6.5 Ensaio para detecção da Caspase-3 ………………........................................... 40

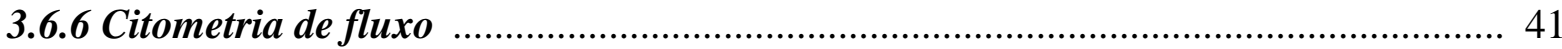

3.6.7 Ação do Complemento sobre células HK-2 …………………............................ 42

3.6.7.1 Morte celular mediada por Complemento ........................................................... 42 
3.6.7.2 Deposição de componentes/reguladores do Complemento 42

3.6.7.3 Análise da ação de inibidores sobre a clivagem de MCP por Western Blot ......... 43

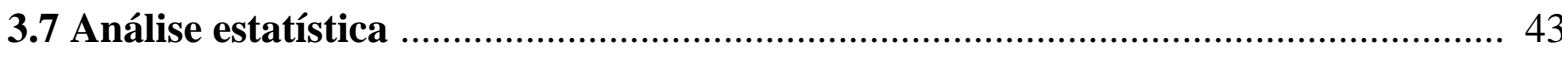

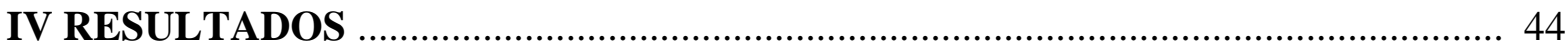

4.1 Purificação da SMase D recombinante P1 de $L$. intermedia ................................... 44

4.2 Análise das atividades funcionais da SMase D recombinante P1 e do veneno de

L. intermedia

4.3 Análise da ação do veneno e da esfingomielinase P1 sobre a viabilidade celular .... 49

4.4 Ativação da Caspase-3 no processo de morte celular induzida por veneno e SMase D P1 de L. intermedia

4.5 Análise da atividade gelatinolítica, induzida pelo veneno e SMase D P1 de $L$. intermedia, por zimografia 53

4.6 Ação da tetraciclina sobre a expressão de MMPs e controle da morte celular ...... 55

4.7 Expressão de MMP-2 e MMP-9

4.8 Ação do veneno e da SMase D P1 sobre os marcadores de superfície das células HK2

4.9 Efeito do veneno e da SMase D P1 sobre os reguladores de membrana do Sistema Complemento em células renais 64

4.10 Morte celular mediada por Complemento 66

4.11 Deposição de componentes de Complemento e outras moléculas do soro na superfície das células HK-2

4.12 Ligação das Esfingomielinases $D$ à superfície das células renais

4.13 Efeito da tetraciclina e da galardina sobre a expressão das moléculas de membrana

4.14 Efeito da tetraciclina e da galardina sobre a expressão do regulador de Complemento MCP e sobre a morte celular por Complemento

4.15 Efeito dos inibidores de ADAM 10 e ADAM 17 sobre a clivagem de MCP e sobre a morte celular por Complemento

4.16 Efeito dos inibidores de ADAM 10 e ADAM 17 sobre a clivagem de $\beta 2$ microglobulina, EPCR e EGFR

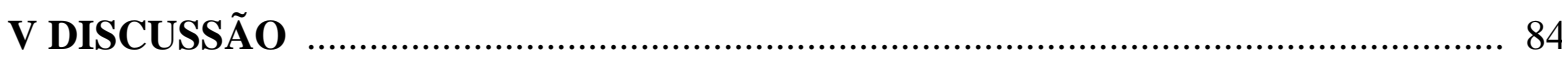

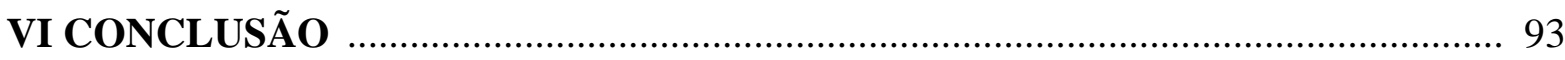

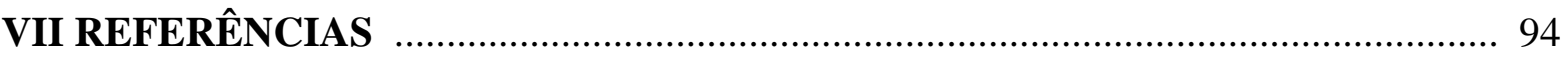


Anexo 1 - OKAMOTO, C. K; GONÇALVES-DE-ANDRADE, R. M.; QUEIROZ, G. P.; GUTIEREZ, V. P.; DE ALMEIDA, D. M.; CURY, Y.; BERTANI, R.; PORTARO, F. C.; TAMBOURGI, D. V. Ctenus medius and Phoneutria nigriventer spiders venoms share noxious proinflammatory activities. J. Med. Entomol., v. 46, n. 1, p. 58-66, 2009.

Anexo 2 - TAMBOURGI, D. V.; PIDDE-QUEIROZ, G.; GONÇALVES-DE-ANDRADE, R. M.; OKAMOTO, C. K.; SOBREIR, T. J.; DE OLIVEIRA, P. S. L.; MURAKAMI, M. T.; VAN DEN BERG, C. W. Molecular Cloning, expression, function, structure and immunoreactivities of a sphingomyelinase D from Loxosceles adelaida, a brazilian brown spider from karstic areas. In: Gregory G. Brown. Molecular Cloning - Selected Applications in Medicine and Biology. In Tech, 2011. 22p.

Anexo 3 - VAN DEN BERG, C. W.; GOLÇALVES-DE-ANDRADE, R. M.; OKAMOTO, C. K.; TAMBOURGI, D. V. C5a receptor is cleaved by metalloproteases induced by sphingomyelinase D from Loxosceles spider venom. Immunobiology, 2012. In press. 


\section{INTRODUÇÃO}

\subsection{Biologia do gênero Loxosceles}

As aranhas pertencem a uma das maiores ordens de aracnídeos (Araneae), sendo descritas mais de 42.000 espécies distribuídas em 110 famílias (PLATNICK, 2011). Esses animais variam desde pequenas espécies com menos de $0,5 \mathrm{~mm}$ de comprimento até as grandes caranguejeiras com comprimento corporal de $9 \mathrm{~cm}$. O corpo das aranhas é dividido em dois tagmas, ou seja, prossoma e opistossoma, que estão conectados por um estreito pedicelo. O prossoma compreende a região anterior e consiste de seis segmentos enquanto a região posterior, o opistossoma, é composta por doze segmentos, facilmente visualizados durante a fase embrionária (DAMEN et al., 1998 e PECHMANN et al., 2010). Além disso, a ordem diferencia-se das outras por apresentar fiandeiras na região posterior do abdômen e pedipalpos utilizados durante a caça de presas ou manipulação dos alimentos; nos machos são também utilizados como órgãos copuladores, equipados com uma estrutura denominada bulbo, que é formado pelo ducto espermático, com função de transferir esperma para fêmea (BARNES; RUPPER, 1984).

A maioria das aranhas alimenta-se de pequenos artrópodes e possui quelíceras, providas de glândulas de venenos, cuja função principal é auxiliar na captura das presas. Grande parte das aranhas não possui veneno tóxico para humanos, porém, em algumas espécies, a picada pode ser nociva. No Brasil são encontrados três gêneros de grande relevância na saúde pública: Phoneutria sp (aranha-armadeira), encontrada em várias regiões do Brasil, principalmente, no sul e sudeste; Loxosceles sp (aranha-marrom) e Latrodectus sp (viúvanegra), sendo esta última encontrada principalmente no litoral nordestino.

O gênero Loxosceles (Família Sicariidae Keyserling, 1880) está perfeitamente adaptado aos mais variados ambientes e foram descritas, até o presente momento, 122 espécies distribuídas, principalmente, nas regiões temperadas e tropicais do mundo. L. deserta Gertsch, 1973 e L. arizonica Gertsh e Mulaik, 1940 são encontradas em Nevada, Arizona, Texas, Novo México e Sudeste da Califórnia; L. reclusa distribui-se pelo norte e sul da América, África, Europa e América do Norte (PLATNICK, 2011).

No Brasil as principais espécies causadoras de acidentes são: L. intermedia MelloLeitão, 1934, predominante nas áreas urbanas do Paraná e Santa Catarina; L. laeta Nicolet, 1849 ocorrendo em focos isolados de várias regiões do país, principalmente no estado de 
Santa Catarina, e L. gaucho Gertsh, 1967, predominante no estado de São Paulo (FISCHER, 1994; LUCAS, 1988; MINISTÉRIO DA SAÚDE, 2001; TAVARES et al., 2004).

Conhecidas popularmente como aranhas-marrons, estas apresentam um desenho característico no cefalotórax que se assemelha a um violino ou estrela. A grande maioria das espécies apresenta uma coloração uniforme, distinguindo-se o sexo destes animais principalmente pelo tamanho dos pedipalpos, maiores nos machos (Figura 1), e pelos receptáculos seminais nas fêmeas (LUCAS, 1988). Além disso, possuem seis olhos arranjados em pares, sendo que um par se localiza anteriormente às quelíceras e dois pares nas laterais formando um semicírculo (RUSSEL et al., 1969; VETTER e VISSCHER, 1998); são animais muito pequenos com comprimento do corpo variando entre 8 a $15 \mathrm{~mm}$ e suas pernas de 8 a 30 mm. São sedentárias e de hábitos noturnos, alojando-se em lugares secos, quentes e escuros, construindo teias irregulares com aparência de algodão, em cascas de árvores, folhas secas, telhas e tijolos empilhados; dentro dos domicílios podem ser encontradas atrás de quadros, cantos de parede, entre livros e roupas penduradas (BURCHERL, 1969; GONÇALVES-DEANDRADE et al., 1999; MINISTÉRIO DA SAÚDE, 2001; MALAQUE et al., 2002). Alimentam-se de pequenos animais e insetos, como formigas, pulgas, cupins e traças. Apesar das aranhas do gênero Loxosceles causarem muitos acidentes, elas não são agressivas e utilizam-se do veneno para paralisar presas ou apenas como um mecanismo de defesa.

Figura 1 - Loxosceles intermedia. [A] macho; [B] fêmea.

A

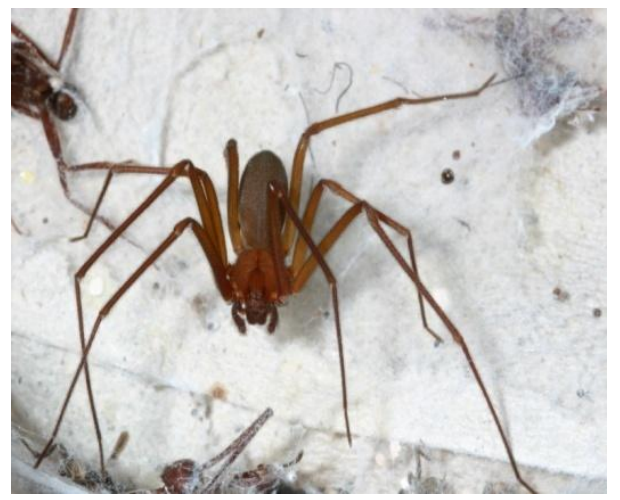

B

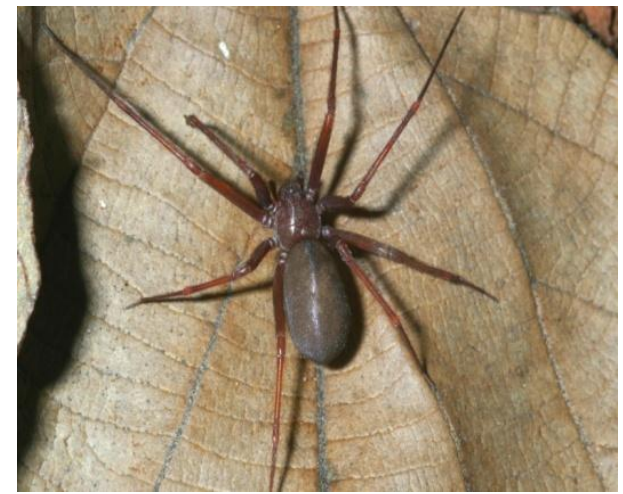

Fonte: Foto gentilmente cedida pela Dra. Rute Maria Gonçalves de Andrade, Laboratório de Imunoquímica, Instituto Butantan. 


\subsection{Veneno e loxoscelismo}

O loxoscelismo é considerado um grave problema de saúde pública e, segundo o Sistema de Informação de Agravos de Notificação do Ministério da Saúde - SINAN correspondeu a cerca de $30 \%$ dos casos de araneísmo notificados em 2011 no Brasil. Anualmente são registrados mais de 6000 casos de envenenamento por Loxosceles (Figura 2), ocorrendo principalmente na região Sul do país (MINISTÉRIO DA SAÚDE - SECRETARIA DE VIGILÂNCIA EM SAÚDE, 2007).

Malaque et al. (2002) analisando 359 casos de loxoscelismo, acompanhados no Hospital Vital Brazil, observaram que $73 \%$ destes ocorreram em áreas urbanas nos períodos mais quentes do ano, entre setembro e fevereiro, e $41 \%$ durante o ato de vestir. As aranhas marrons atacam, apenas, quando comprimidas contra o corpo e, por isso, cuidados com roupas pessoais e acessórios de cama podem prevenir os acidentes (FUTRELL, 1992; MALAQUE et al. 2002).

Figura 2 - Notificação Anual de Acidentes por Loxosceles no Brasil (2001-2011).

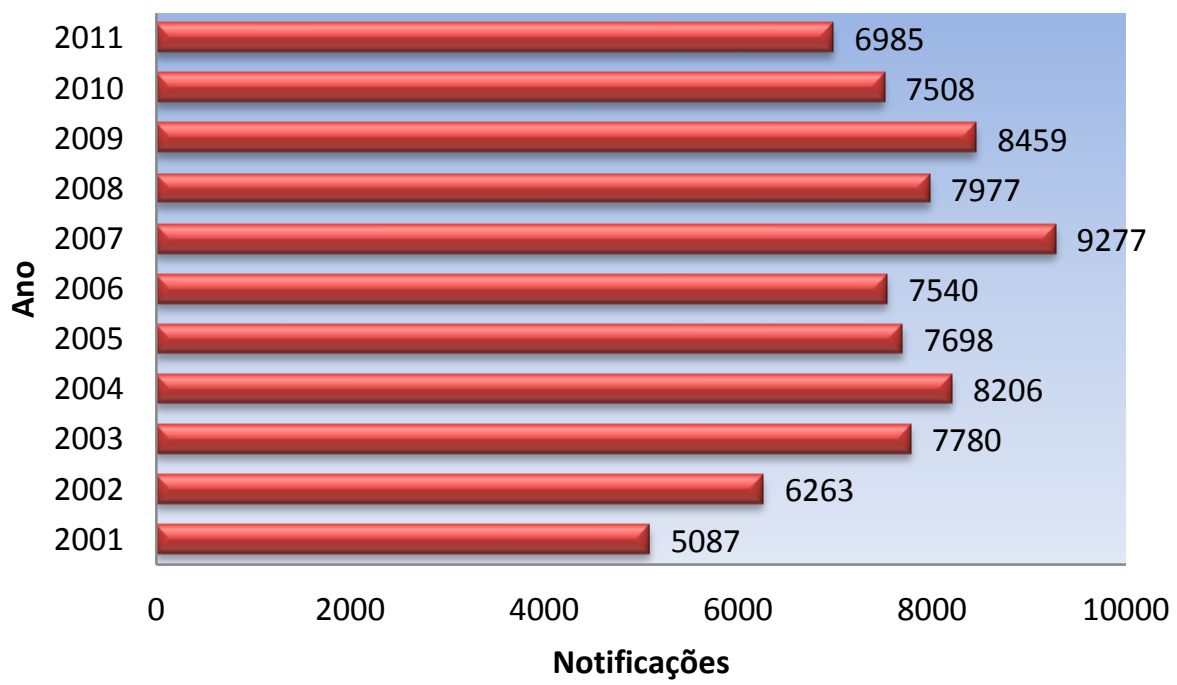

Fonte: Ministério da Saúde/SVS - Sistema de Informação de Agravos de Notificação - SINAN. 
A picada da aranha é praticamente imperceptível e raramente se observa lesão imediata. Envenenamentos por Loxosceles resultam em lesões locais e reações sistêmicas; geralmente o indivíduo apresenta os primeiros sintomas após 2-8 horas da picada. A dor local se intensifica e os pacientes apresentam cefaléia, febre, equimose no local da picada com eritema e edema duro levando à isquemia (FUTRELL, 1992; MINISTÉRIO DA SAÚDE, 2001). Estas lesões, quando não tratadas, podem levar à necrose, o que ocorre por volta de 3 a 7 dias (SILVA et al., 2004). O veneno de Loxosceles é considerado muito potente, já que a aranha elimina, por meio da sua picada, apenas alguns microlitros de veneno, contendo não mais que $30 \mu \mathrm{g}$ de proteína (TAMBOURGI et al., 2000).

Variações intraespecíficas, relacionadas à idade e sexo, ou interespecíficas podem interferir na toxicidade do veneno das aranhas Loxosceles (GONÇALVES-DE-ANDRADE et al., 1999; OLIVEIRA et al., 1999; 2005; PRETEL et al., 2005). Estudos realizados por Oliveira et al. $(1999,2005)$ demonstraram que as fêmeas produzem maior quantidade de veneno e podem causar reações dermonecróticas mais intensas do que os machos. Em ensaios in vitro, o veneno de fêmeas foi também capaz de induzir hemólise, dependente de Complemento, mais intensa.

Vários estudos têm identificado algumas enzimas como componentes do veneno de Loxosceles, incluindo lipases, hialuronidases, colagenases, esfingomielinases e fosfatases (FUTRELL, 1992).

A partir de estudos realizados por Rees et al. (1983) foi demonstrado que uma fração isolada do veneno de L. reclusa, com peso molecular de $32 \mathrm{kDa}$, era capaz de induzir hemólise. Tambourgi et al. (1995; 1998a) caracterizaram o veneno de L. intermedia e verificaram que este era também capaz de induzir hemólise dependente da ativação do sistema complemento. Por cromatografia de exclusão molecular, os componentes tóxicos do veneno foram isolados, sendo que a fração contendo proteínas com peso molecular de $35 \mathrm{kDa}$, denominada F35, induziu forte reação dermonecrótica, em coelhos, e tornou eritrócitos humanos sensíveis à lise mediada pelo Sistema Complemento; a F35 foi também letal para camundongos (TAMBOURGI et al., 1995; 1998a e b). Além disso, foi capaz de induzir, em modelo murino, um quadro semelhante ao do choque endotóxico, com a produção de altos níveis de TNF- $\alpha$, IL-6 e óxido nítrico (TAMBOURGI et al., 1998a).

A F35 foi submetida à cromatografia de fase reversa e três isoformas, denominadas P1, P2 e P3, foram obtidas. As proteínas P1 e P2 possuem um alto grau de homologia nas suas sequências N-terminal de aminoácidos (89\%), enquanto a homologia entre P1/P2 e P3 foi de 
$60 \%$. P1 e P2 foram capazes de clivar esfingomielina, enquanto P3 foi incapaz de promover tal hidrólise. A atividade esfingomielinásica de P1 e P2 pode ser inibida por EDTA, sugerindo que a atividade catalítica era dependente de íons (TAMBOURGI et al., 1998a). Além de possuírem atividade esfingomielinásica, foram também capazes de induzir hemólise dependente de Complemento e dermonecrose, enquanto P3 foi inativo.

Em 2004, Tambourgi et al. clonaram e expressaram as esfingomielinases P1 e P2 de $L$. intermedia, a partir do mRNA extraído das glândulas de venenos das aranhas. Assim como as esfingomielinases purificadas do veneno bruto, as proteínas recombinantes foram capazes de clivar a esfingomielina e induzir hemólise dependente de complemento. Em ensaios biológicos de dermonecrose em coelhos, as proteínas recombinantes P1 e P2 foram capazes de causar lesões semelhantes às provocadas pelo veneno bruto de L. intermedia (TAMBOURGI et al., 2004).

A partir do mRNA extraído da glândula de veneno da Loxosceles laeta, FernandesPedrosa (2008) descreveram o repertório de transcritos expressos, por meio da análise de ESTs (expressed sequence tags). Assim mostrou que 16,4\% do total dos transcritos correspondem a proteínas com sequências conhecidas, incluindo neurotoxinas e esfingomielinases D, predominantes nesta categoria. Outra categoria, denominada de “possíveis toxinas" correspondeu a 14,5 \% do total dos ESTs e neste grupo foram incluídas metaloproteases, serinoproteases, cisteíno-peptidases, lipases, aspártico-proteases, inibidores enzimáticos, lectinas e hialuronidases. 33,3\% do total dos transcritos corresponderam a proteínas envolvidas em várias funções celulares como expressão de genes e proteínas, possivelmente, contribuindo para a função deste tecido especializado em síntese protéica. Por fim, cerca de $25 \%$ dos ESTs não apresentaram similaridade com sequências já conhecidas.

\subsection{Loxoscelismo cutâneo}

O loxoscelismo cutâneo ocorre na maioria das vítimas, cerca de $80 \%$ dos casos. O envenenamento por Loxosceles inicialmente causa um pequeno desconforto, começando por uma expansão de eritema e edema, podendo provocar um extenso dano tecidual após 8 a 24 horas do acidente (ATKINS et al., 1958; WASSERMAN e ANDERSON, 1984; FUTRELL, 1992). Sintomas como dor, iniciando-se entre 2-8 horas após a picada, e isquemia tecidual também são característicos da reação cutânea. 
Tambourgi et al. (2005) demonstraram que o Sistema Complemento (C) participa no desenvolvimento do loxoscelismo cutâneo por meio do recrutamento de neutrófilos, como consequência da geração de C5a e do complexo de ataque à membrana (MAC). Ensaios nos quais a depleção de Complemento foi promovida mostraram uma importante redução no infiltrado de neutrófilos, embora tenham sido ainda observadas hemorragia e dissociação das fibras colágenas. A participação dos neutrófilos na dermonecrose foi também demonstrada experimentalmente em camundongos, nos quais a depleção de polimorfonucleares foi induzida, com conseqüente redução nos danos vasculares (SUNDERKÖTTER et al., 2001). No entanto, foi verificado que a expressão de metaloproteases de matriz extracelular, induzidas pelas esfingomielinases do veneno, é possivelmente um dos principais fatores envolvidos na gênese do loxoscelismo cutâneo (TAMBOURGI et al., 2005; PAIXÃOCAVALCANTE et al., 2006, 2007).

Estudos in vivo, com coelhos e, in vitro, realizados com queratinócitos humanos da linhagem HaCat, mostraram que o veneno, assim como as esfingomielinases de L. intermedia, induziram aumento na expressão das metaloproteases de matriz extracelular, MMP-2 e MMP9, diminuição da viabilidade celular por apoptose e aumento do infiltrado inflamatório no local da lesão (TAMBOURGI et al., 2005; PAIXÃO-CAVALCANTE et al., 2006). Para mostrar a participação dessas metaloproteases na morte celular e inflamação, foram realizados ensaios utilizando inibidores de metaloproteases de matriz extracelular como a tetraciclina, doxiciclina e monociclina. Desta forma, foi observada não só a inibição da expressão das gelatinases MMP-2 e MMP-9, como também da degradação de DNA e da morte celular, controlando, assim, o desenvolvimento da reação dermonecrótica (PAIXÃO-CAVALCANTE et al., 2006, 2007).

\subsection{Loxoscelismo Sistêmico}

O loxoscelismo sistêmico é menos comum do que o cutâneo, ocorrendo em aproximadamente $16 \%$ das vítimas, com maior incidência em crianças (FUTRELL, 1992). Pode ocorrer febre, prurido, exantema e formação de trombo, hemólise intravascular, agregação plaquetária, inflamação persistente e, em casos mais severos, falência renal e morte (FUTRELL, 1992; SCHENONE et al., 1998). Ainda foram demonstradas, experimentalmente em modelo murino, alterações como hipotermia, hipotensão e dificuldade respiratória (TAMBOURGI et al., 1998b). 
A ativação do Sistema Complemento pela via alternativa é um dos mecanismos responsável pela hemólise. Eritrócitos tratados com o veneno ou suas esfingomielinases apresentam ativação de metaloproteases endógenas, que clivam as glicoforinas A, B, C e D, presentes na membrana da célula, causando a remoção do ácido siálico. Tal fato permite que ocorra a deposição de componentes do complemento na superfície das células, culminando na formação de complexo de ataque à membrana (MAC) e resultando em hemólise (TAMBOURGI et al., 1995, 1998a, 2000). O veneno e suas esfingomielinases podem, ainda, ativar a via clássica do Complemento por meio da alteração da assimetria de membrana com a exposição de fosfatidilserina, o que facilita a ligação de C1q à membrana dos eritrócitos (TAMBOURGI et al., 2002, 2007).

Ensaios in vitro com células endoteliais ECV 304, incubadas com as esfingomielinases ou com veneno de L. intermedia, mostraram a ativação de metaloproteases endógenas, fato associado à redução significativa da expressão do regulador do Sistema Complemento MCP e de moléculas de membrana como MHCI e $\beta 2$ microglobulina. A participação das metaloproteases, na remoção destes marcadores, pode ser confirmada com o uso de galardina, um inibidor de metaloproteases da família das adamlisinas. No entanto, a redução de MCP não causou uma maior susceptibilidade à lise, mas sim, uma maior resistência à lise mediada por Complemento (van den BERG et al., 2002). Os mecanismos para esta resistência não foram ainda esclarecidos.

A falência renal, que é responsável pela maioria dos óbitos em pacientes com loxoscelismo, parece ocorrer por mecanismos de toxicidade direta e indireta, ainda não totalmente esclarecidos. Tambourgi et al. (1998b) observaram, em camundongos injetados com veneno de L. intermedia ou suas esfingomielinases, alterações nos rins como necrose tubular aguda e deposição de material eosinofílico nos túbulos distais e proximais. Edema, presença de hemácias no espaço extracelular e degeneração vacuolar nos túbulos proximal e distal também foram descritas no envenenamento por Loxosceles por Luciano et al. (2004). A hemoglobinúria decorrente do envenenamento pode ser um componente importante na injúria renal, reduzindo o fluxo sanguíneo nos rins e resultando em necrose tubular (MALHOTRA et al., 1978; LUNG et al., 2000). Por outro lado, Chaim et al. (2006); Kusma et al. (2008), em ensaios in vitro com células renais MDCK, mostraram perda de viabilidade das células quando tratadas com a toxina dermonecrótica recombinante LiRecDT, isolada da glândula de veneno de L. intermedia, indicando toxicidade direta sobre as células renais. Por outro lado, ensaios realizados por Lucato et al. (2011), utilizando ratos inoculados com veneno de $L$. 
gaucho, demonstraram que a disfunção renal ocorre devido à vasoconstrição intra-renal e rabdomiólise e não por citoxicidade direta.

\subsection{Rim}

O rim tem como principal função eliminar substâncias tóxicas provindas do metabolismo, mantendo o equilíbrio osmótico e ácido-básico. O rim é organizado por unidades funcionais, os néfrons, constituídos pelo glomérulo e por um longo túbulo que desemboca nos tubos coletores de urina (Figura 3). Cada néfron é capaz de filtrar e formar urina independente dos demais. Localizado na região do córtex do rim, o túbulo proximal, cuja parede é formada por células adaptadas ao transporte ativo, é responsável pela reabsorção de cerca de $70 \%$ da quantidade de água filtrada nos capilares glomerulares; possui um papel fundamental na reabsorção de substâncias essenciais ao organismo, como a glicose, aminoácidos, proteínas, moléculas de $\mathrm{Na}^{+}$e $\mathrm{Cl}^{-}$, fosfato, bicarbonato e água (PRITCHARD, MILLER, 1996; WRIGHT, DANTZLER, 2004; PANCHAPAKESAN et al., 2009; BLODGETT, et al., 2011; BOKËNKAMP, LUDWING, 2011).

Além disso, ensaios in vitro, utilizando culturas de células do túbulo proximal da linhagem PTEC, mostraram que estas são capazes de produzir alguns mediadores proinflamatórios, como as citocinas TNF- $\alpha$ e IL-6, quimiocinas IL-8 e MCP-1 (monocyte chemotactic protein-1), fatores de crescimento (GM-CSF) e proteínas do Sistema Complemento C2, C3, C4, fator B e fator H (JEVNIKAR et al., 1991; ROVIN, PHAN, 1998; van KOOTEN et al, 1999).

Células do túbulo proximal expressam, em sua superfície, receptores como o endotelial para proteína C (EPCR) e para o fator de crescimento epidermal (EGFR), que parecem estar envolvidas nos eventos de proliferação e sobrevivência celular e que foram também associadas a algumas patologias renais (PANCHAPAKESAN et al., 2009; BAE et al., 2010). Injúrias no túbulo renal que levam à proteinúria, isquemia e exposição à nefrotoxinas são as causas mais comuns da disfunção renal aguda (BENNETT et al., 1991, ABBATE et al., 2006). A ativação do Sistema Complemento tem sido associada à muitas doenças renais, como inflamações e isquemias (MORGAN, HARRYS, 2003). Proteínas presentes na urina podem causar ativação direta do Sistema Complemento, contribuindo para a injúria local. Moléculas do Complemento, como C3, estão presentes em maior quantidade na urina de pacientes com proteinúria, o que permite a ativação, principalmente, da via alternativa, 
contribuindo para o dano renal (BIANCONE et al, 1994; MORITA et al, 2000; SHEERIN et al., 2008). Por outro lado, deficiências de algumas proteínas do Complemento como C3, C5 e C6 podem contribuir para a proteção contra a isquemia renal (ZHOU et al, 2000; DE VRIES et al, 2003) e mutações de proteínas reguladoras do Complemento, como fator $\mathrm{H}, \mathrm{MCP}$ e fator I têm sido descritas em muitos pacientes com síndrome urêmica hemolítica (PICKERING et al, 2007; LEE et al, 2009).

Figura 3 - Ilustração representativa do Rim. [A] Veia Renal; [B] Artéria Renal; [C] Uréter; [D] Medula; [E] Pélvis; [F] Córtex. Néfron: [1] Ramo ascendente da alça de Henle; [2] Ramo descendente da alça de Henle; [3] Capilares peritubulares; [4] Túbulo Proximal; [5] Glomérulo; [6] Túbulo Distal.

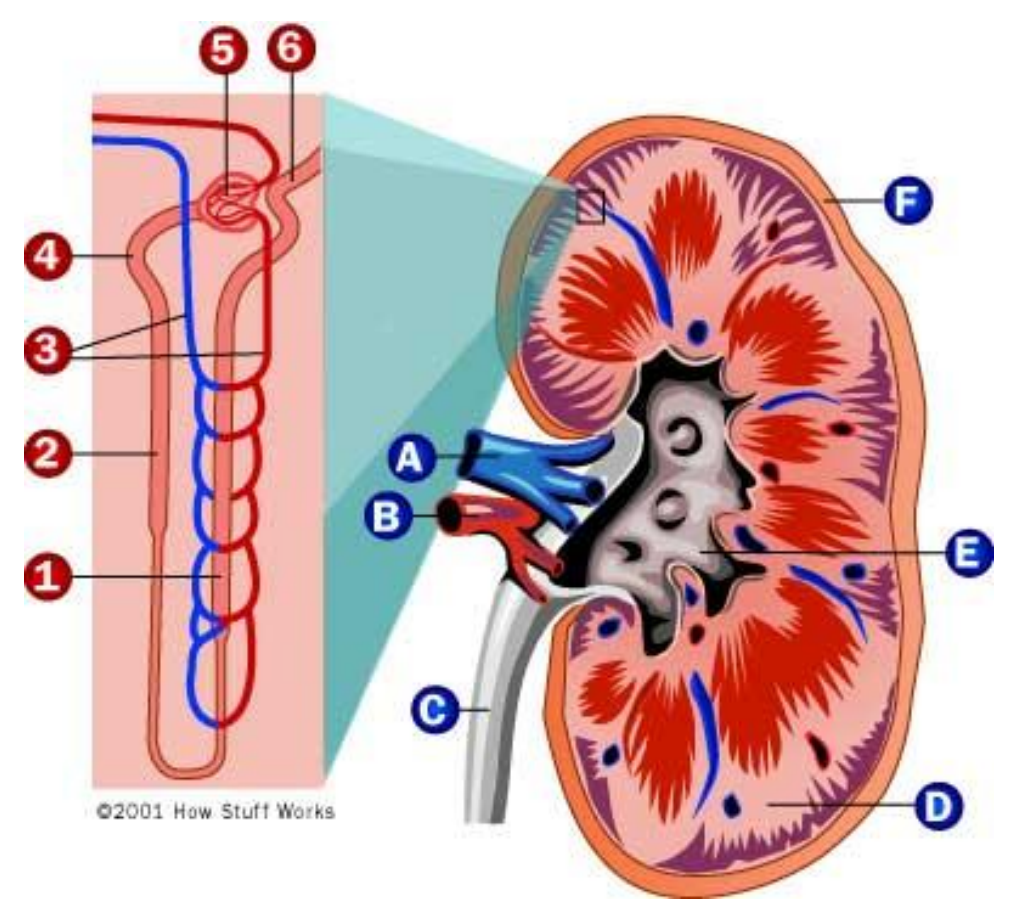

Fonte: Zivkovic, B. - Scientific American, 2009. 


\subsection{Terapia}

A soroterapia é o tratamento mais comumente utilizado nos acidentes por Loxosceles no Brasil. No entanto, outros procedimentos incluem o uso de corticosteróides, heparina e fentolamina (DILLAHA et al., 1964; REES et al., 1981; MALAQUE et al., 2002). A administração de dapsona e oxigênio hiperbárico são terapias utilizadas, principalmente, como moduladoras da resposta inflamatória (KING e REES, 1983; STRAIN et al., 1991; MINISTÉRIO DA SAÚDE, 2001; MALAQUE et al., 2002; HOGAN et al., 2004). Em casos mais graves podem ser, ainda, realizadas excisões cirúrgicas das lesões necróticas, transfusão de sangue e hemodiálise (RIBEIRO et al., 1993).

Os tratamentos empregados, até o momento, não são efetivos nos casos de maior gravidade e, por isso, a busca de uma melhor caracterização dos mecanismos moleculares de ação do veneno é relevante para o estabelecimento de propostas terapêuticas mais eficazes para o loxoscelismo. Paixão-Cavalcante et al. (2006, 2007) demonstraram que o uso da tetraciclina pode ser uma alternativa eficaz no tratamento das lesões dermonecróticas provocadas pelo envenenamento por Loxosceles, uma vez que esta induz uma diminuição na expressão de metaloproteases MMP-2 e MMP-9 e da morte celular por apoptose. Manzonide-Almeida et al. (2008) produziram um novo soro anti-loxoscélico a partir da imunização de cavalos com as SMases P1 e P2 recombinantes de L. intermedia e SMase I de L. laeta e mostraram que a neutralização é alta contra a atividade tóxica dos venenos de L. intermedia e L. laeta e similar à ação do soro anti-aracnídico na neutralização do veneno de L. gaucho.

\subsection{Sistema Complemento}

O Sistema Complemento consiste em um conjunto de proteínas, algumas delas com atividade enzimática, presente no soro e na superfície celular que interagem entre si e com outras moléculas do sistema imune de modo altamente regulado. É um dos principais mecanismos efetores da resposta imune humoral e da imunidade inata nos mamíferos, participando na formação de poros na superfície celular, principalmente em bactérias, na opsonização de patógenos, na resposta inflamatória auxiliando no combate à infecção, remoção de células apoptóticas e de imunocomplexos (BOTTO et al, 2009; WALPORT, 2001; KEMPER, ATKINSON, 2007). Em humanos existem mais de 30 proteínas do Complemento, incluindo os receptores de superfície celular e as proteínas regulatórias (REID, 
PORTER, 1981; NANGAKU, 1998; KÖHL, 2006; UNSWORTH, 2008), sendo que parte delas participa nas vias de ativação, ou seja, as vias clássica, alternativa e das lectinas, que são ativadas por diferentes estímulos (Figura 4).

O Sistema Complemento é um mecanismo de defesa ancestral, presente já em invertebrados deuterostomos e em vertebrados mais primitivos, sendo a via alternativa a única presente nestes animais. A via clássica surge nos peixes cartilaginosos, sendo preservada no processo evolutivo, e a das lectinas é encontrada nos protocordados com o aparecimento das moléculas MBL e MASP (JI et al., 1997, SUNYER, LAMBRIS, 1998; ZARKADIS et al., 2001).

A molécula de $\mathrm{C} 1 \mathrm{q}$ do componente $\mathrm{C} 1\left(\mathrm{C} 1 \mathrm{q}-\mathrm{C}_{1} \mathrm{r}_{2}-\mathrm{C} 1 \mathrm{~s}_{2}\right)$ pode iniciar a ativação da via clássica do Complemento, por interação com imunocomplexos, contendo IgG ou IgM, com CRP (Proteína C Reativa), SAP (Proteína Soro Amilóide), DNA, RNA ou por associação direta à fosfatidilserina presente na superfície de células em que a assimetria de membrana foi rompida (RUDDY, AUSTEN, 1975; BERGER e DAHA, 2007; SJÖBERG et al., 2009). A associação de C1q a estes fatores induz ativação de C1r que cliva e ativa C1s. C1s ativado cliva os componente $\mathrm{C} 4$, gerando $\mathrm{C} 4 \mathrm{a}$ e $\mathrm{C} 4 \mathrm{~b}$, e $\mathrm{C} 2$, gerando $\mathrm{C} 2 \mathrm{a}$ e $\mathrm{C} 2 \mathrm{~b}$. C4b liga-se ao fragmento $\mathrm{C} 2 \mathrm{a}$, formando o complexo $\mathrm{C} 4 \mathrm{bC} 2 \mathrm{a}$, é a C3 convertase da via clássica.

A via das lectinas inicia-se pela ligação das proteínas denominadas MBL (mannose binding lectin) ou ficolinas a carboidratos presentes na superfície de microorganismos, levando à ativação das MASPs (mannose-binding protein-associated serine proteases), principalmente MASP-2 que, assim como os componentes da via clássica, ativam e clivam o componente C4 e C2 para a formação da C3 convertase (STAHL e EZEKOWITZ, 1998, VORUP-JENSEN, 2000, THIEL et al., 2009).

A ativação da via alternativa inicia-se pela hidrólise espontânea do componente $C 3$, gerando $\mathrm{C} 3\left(\mathrm{H}_{2} \mathrm{O}\right)$ que se liga ao fator $\mathrm{B}$, formando o complexo $\mathrm{C} 3\left(\mathrm{H}_{2} \mathrm{O}\right) \mathrm{B}$; o fator $\mathrm{B}$ sofre clivagem pelo fator $\mathrm{D}$, gerando uma $\mathrm{C} 3$ convertase que, na presença de íons $\mathrm{Mg}^{2+}$, age sobre o componente C3, clivando-o (BEXBORN et al., 2008; SJÖBERG et al., 2009). Os fragmentos C3b se ligam a novas moléculas do fator B que sofrem hidrólise pelo fator D, gerando a C3 convertase de amplificação, ou seja, o complexo C3bBb (FEARON e AUSTEN, 1975).

Após a formação das C3 convertases das vias clássica, das lectinas e alternativa, estas clivam o componente $\mathrm{C} 3$ em $\mathrm{C} 3 \mathrm{~b}$ e $\mathrm{C} 3 \mathrm{a}$. $\mathrm{O}$ fragmento $\mathrm{C} 3 \mathrm{~b}$ associa-se às $\mathrm{C} 3$ convertases para a formação da C5 convertase, que cliva o componente C5 em C5a e C5b. A cascata de ativação converge, então, para uma via terminal comum, iniciando a formação do complexo 
de ataque à membrana (MAC), composto pelos componentes C5b, C6, C7, C8 e C9, o que resulta na formação de poros na superfície celular e lise osmótica da célula alvo (MORGAN, 1999).

O Sistema Complemento é composto, além das proteínas que participam das vias de ativação, por proteínas regulatórias, presentes na membrana celular ou no plasma, que protegem o hospedeiro contra ativações descontroladas desse sistema (BERGER e DAHA, 2007). A maioria destas proteínas age na regulação das convertases, formadas durante a ativação da cascata do complemento, seja pela aceleração do decaimento das enzimas ou agindo como cofator, para a degradação enzimática de $\mathrm{C} 3 \mathrm{~b}$ e $\mathrm{C} 4 \mathrm{~b}$, pelo fator I.

$\mathrm{O}$ regulador MCP (Membrane cofactor protein, CD46), expresso em vários tipos celulares, com exceção dos eritrócitos, regula a ativação da C3 convertase, atuando como cofator do fator I na clivagem de C3b e C4b (NANGAKU, 1998; KIM et al., 2006). CR1 (Complement Receptor Type 1, CD35) está presente em vários tipos celulares, incluindo os eritrócitos, e promove a dissociação das C3 e C5 convertases; além disso exerce atividade de cofator para o fator I, promovendo a clivagem e inativação de $\mathrm{C} 3 \mathrm{~b}$ e $\mathrm{C} 4 \mathrm{~b}$ (KRYCHGOLDBERG et al., 1999). DAF (decay-accelerating factor, CD55), presente também na membrana de vários tipos celulares, não exerce atividade de cofator, mas atua na aceleração do decaimento das C3 e C5 convertases, liberando a proteína Bb da via alternativa e C2a da via clássica (HARRIS et al., 2007). O regulador solúvel C4bp liga-se ao fragmento C4b e atua como cofator para ação do fator I e, também, acelera o decaimento das C3 convertases das vias clássica e das lectinas (BLOM et al., 2004). O fator H, presente na forma solúvel, acelera o decaimento das C3 e C5 convertases da via alternativa, e atua também como cofator para ação do fator I, na clivagem do componente C3b (CÓRDOBA et al., 2004). O inibidor de C1 (C1INH), presente na forma solúvel, controla a ativação do complexo $\mathrm{C} 1$, bloqueando a atividade proteolítica de C1r e C1s (ROSEN, DAVIS III, 2005), assim como a das MASPs. O regulador de membrana CD59 bloqueia a formação do complexo de ataque à membrana (MAC), pela inibição da incorporação de C8 e C9 ao MAC (BARILLA-LaBARCA et al., 2002; SJÖBERG et al., 2009).

Alguns estudos têm demonstrado que, na patologia renal, o Sistema Complemento participa como um importante elemento imunomodulador. Assim, foi mostrado que a formação de imunocomplexos no tecido renal, pela resposta de anticorpos contra antígenos próprios, a regulação ineficiente da cascata do complemento, ou ainda, a ligação de fatores que levam à ativação do Complemento como a properdina, podem levar à injúria renal 
(EDELWEISS et al., 1997; NANGAKU, 1998; SHOJI et al., 2000, BERGER, DAHA, 2007, GAARKEUKEN et al., 2008, SIEZENGA et al., 2009, VAN DER POL et al., 2011).

A injúria intersticial, com decorrente proteinúria, pode ocorrer como consequência da formação de imunocomplexos e ativação da via clássica de Complemento, como também da via alternativa, levando a uma ativação descontrolada do Sistema (GAARKEUKEN et al., 2008). Ensaios in vitro, com células renais da região do tubo proximal, realizados por He et al. (2005), mostraram que o uso de inibidores como o do MAC, o CD59, e das convertases, o Crry, regulador semelhante ao MCP presente em camundongos, era capaz de promover redução na injúria renal. Outra doença que pode afetar o rim, a síndrome hemolítica-urêmica (SHU), pode ser desencadeada em indivíduos portando mutações nos genes que codificam para os fatores $\mathrm{H}$, I ou MCP, levando a perda de função destes reguladores, com conseqüente ativação desregulada do componente C3 (ATKINSON, GOODSHIP, 2007; JÓZSI e ZIPFEL, 2008; BUELLI et al., 2009). Estudos recentes também mostraram que a MBL pode reconhecer ligantes endógenos presentes nas células renais isquêmicas, o que resulta na ativação da via das lectinas, levando à injúria renal (MOLLER-KRISTENSEN et al., 2005; JANG e RABB, 2009). 
Figura 4 - Sistema Complemento. O Sistema Complemento pode ser ativado por meio de três Vias: Clássica, Lectinas ou Alternativa. A ativação do Complemento pode ser controlada por proteínas regulatórias, presentes na membrana celular ou no plasma, que protegem o hospedeiro contra ativações descontroladas.

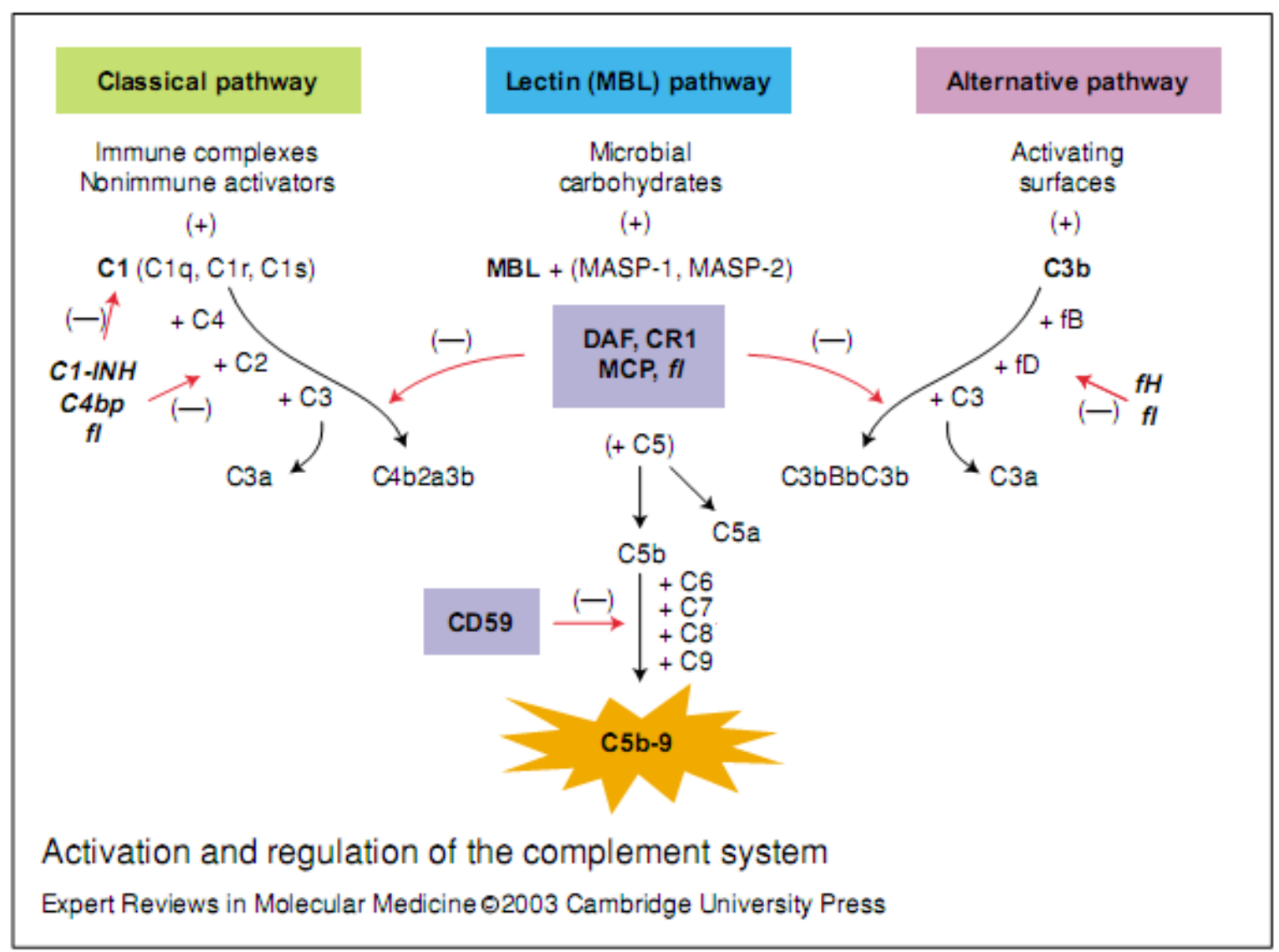

Fonte: Modificado de Francis et al (2003). 


\section{OBJETIVO}

O objetivo deste trabalho foi investigar os mecanismos envolvidos na injuria renal induzida pelo veneno de Loxosceles intermedia e pela esfingomielinase D recombinante P1, utilizando como modelo experimental células renais humanas da linhagem HK-2. Com este modelo foram analisados:

— O potencial tóxico do veneno de L. intermedia e da SMase D;

- A participação da ativação das cascatas do Sistema Complemento na gênese dos danos celulares induzidos pelo veneno de L. intermedia e da SMase D;

- A integridade dos reguladores de membrana do Complemento nas células renais, após tratamento com o veneno ou com a SMase D;

- O papel de metaloproteinases no dano celular e ação de inibidores, como a tetraciclina e a galardina, no controle das injúrias. 


\section{MATERIAL E MÉTODOS}

\subsection{Reagentes e tampões}

Tetraciclina, esfingomielina, colina oxidase, peroxidase, ácido 3-(4-hidroxil-fenil) propiônico, MTT (3-[4,5-dimetil-tiazol-2-il]-2,5-difenil-tetrazólio), azul de Comassie e paraformaldeído foram obtidos da Sigma-Aldrich (EUA). Galardina (GM6001) e DMSO (dimetilsulfóxido) foram obtidos da Calbiochem (Merck, Alemanha). DMEM (Dulbecco's Modified Eagle Medium), RPMI 1640, IPTG (isopropyl- $\beta$-D thiogalactopyranoside), penicilina e estreptomicina foram obtidas da Invitrogen (EUA) e iodeto de propídeo da BD Biociences (EUA). NBT (nitro-blue tetrazolium chloride)/ BCIP (5-bromo-4-chloro-3'indolyphosphate p-toluidine salt) foi obtido da Molecular Probes (EUA). Inibidores para ADAM 10 (GI254023) e ADAM 17 (GW280264) foram gentilmente cedidos pela Dra. Ann Anger (Universidade de Cardiff, Reino Unido). Os tampões utilizados foram: Salina ( $\mathrm{NaCl}$ $0,85 \%), \operatorname{VBS}^{++}\left(0,9 \mathrm{mM}\right.$ de sódio barbital, $0,3 \mathrm{mM}$ de $\mathrm{CaCl}_{2}, 2,8 \mathrm{mM}$ de ácido barbitúrico e $0,8 \mathrm{mM}$ de $\mathrm{MgCl}_{2}, \mathrm{pH} 7,2$ ); FACS (PBS, BSA $1 \%$ e $0,01 \%$ de azida sódica).

\subsection{Anticorpos}

Anticorpo monoclonal murino anti-MCP humano (CD46) foi gentilmente cedido pelo Dr. John Atkinson (EUA). Anticorpos monoclonais murinos anti-CD59 e DAF (CD55) humanos foram obtidos da IBRGL (Reino Unido). Anticorpos monoclonais anti-MHC I, $\beta 2$ microglobulina, EGFR, MBL, EPCR e properdina foram obtidos da BD Biociences (EUA). Anticorpos policlonais anti-SMase D foram obtidos por imunização de cavalos com as esfingomielinases D recombinantes P1 e P2 de L. intermedia e H17 de L. laeta e cedidos pela Seção de Plasmas Hiperimunes do Instituto Butantan. Anticorpos policlonais anti-C3, C4, fator B, fator $\mathrm{H}$ e anticorpos monoclonais anti-C1q e C4bp foram obtidos da Quidel (EUA). Anticorpos dirigidos contra as pentraxinas CRP e SAP foram obtidos da Calbiochem (EUA). Anticorpos conjugados anti-IgG de coelho, cabra, cavalo ou camundongo, conjugados com FITC (isotiocianato de fluoresceína) foram obtidos da Sigma-Aldrich (EUA). Anticorpo conjugado anti-IgG de camundongo, conjugado com fosfatase alcalina foi obtido da Promega (EUA). 


\subsection{Veneno de L. intermedia}

O veneno da aranha L. intermedia Mello-Leitão foi fornecido pelo Biotério de Aranhas do Laboratório de Imunoquímica do Instituto Butantan (Registro IBAMA 1/35/95/1561, processo $n^{\circ}$ 02027016615/95-92). O veneno foi obtido por eletroestimulação, segundo o método de Burcherl (1969), com pequenas modificações. Resumidamente, estímulos elétricos de 15 a $20 \mathrm{~V}$ foram repetidamente aplicados sobre o esterno da aranha e as gotas de veneno recolhidas com o auxílio de micropipeta e preparadas em solução salina estéril. O veneno foi aliquotado e estocado a $-20{ }^{\circ} \mathrm{C}$. O conteúdo protéico foi determinado pelo método de Lowry (LOWRY et al., 1951).

\subsection{Expressão e purificação da proteína recombinante}

Colônias de bactérias E. coli BL21 ( $\left.\mathrm{DE}_{3}\right)$ (Invitrogen, EUA) foram transformadas com o vetor de expressão pRSET-B (Invitrogen, EUA), contendo o gene correspondente à toxina P1 de L. intermedia (TAMBOURGI et al., 2004). Estas foram incubadas em meio 2YT na presença de ampicilina e crescidas a $37^{\circ} \mathrm{C}$ até atingir a $\mathrm{DO}_{600} 0.6$. A expressão gênica foi induzida pela adição de $5 \mathrm{mM}$ de IPTG ao meio. Após a indução, as bactérias foram lisadas por sonicação e centrifugadas a $10.000 \mathrm{rpm}$ durante $60 \mathrm{~min}$ a $4{ }^{\circ} \mathrm{C}$. O sobrenadante foi submetido à cromatografia de afinidade em coluna Ni (II) Chelating Sepharose Fast Flow (Amersham Biosciences, Suécia).

O material não adsorvido foi eluído com tampão "binding” (0,02 $\mathrm{M}$ de $\mathrm{Na}_{3} \mathrm{PO}_{4}, 0,5 \mathrm{M}$ de $\mathrm{NaCl}-\mathrm{pH} 7,8)$ e "wash" $\left(0,2 \mathrm{M}\right.$ de $\mathrm{Na}_{3} \mathrm{PO}_{4}, 0,5 \mathrm{M}$ de $\mathrm{NaCl}-\mathrm{pH}$ 6,0) e as proteínas recombinantes, adsorvidas à coluna, foram eluídas em tampão "wash" contendo concentrações crescentes de imidazol. As amostras contendo as esfingomielinases recombinantes foram concentradas em Amicon Ultra 30.000 MW (Millipore, EUA) e o conteúdo protéico determinado utilizando-se o método de Lowry. As amostras foram aliquotadas e estocadas a $-80^{\circ} \mathrm{C}$ até o momento do uso. 


\subsection{Análise das amostras da proteína recombinante P1}

\subsubsection{Eletroforese em gel de SDS-PAGE}

Amostras das frações coletadas, durante o processo de purificação da SMase D recombinante $\mathrm{P} 1$, foram submetidas à eletroforese vertical, sob condições redutoras, na presença de $\beta$-mercaptoetanol, em gel de poliacrilamida e duodecil sulfato de sódio (SDSPAGE) como descrito por Laemmli (1970). Os perfis eletroforéticos foram determinados em géis a $12 \%$ sob voltagem de $100 \mathrm{~V}$, no sistema Mighty Small (Hoefer Pharmacia Biotech, EUA). Os pesos moleculares das proteínas presentes nas amostras foram determinados por comparação de migração com uma mistura de proteínas de calibração, com pesos moleculares conhecidos (BrenchMark ${ }^{\mathrm{TM}}$ Pré-stained Protein Ladder Invitrogen, EUA). Após a corrida, o gel foi corado por impregnação pela prata (MORRISSEY, 1980).

\subsubsection{Atividade esfingomielinásica}

A atividade hidrolítica do veneno e da proteína recombinante P1 de L. intermedia sobre esfingomielina (SM) foi mensurada pelo método descrito por Tokumura et al. (2002). $50 \mu \mathrm{M}$ do substrato (Sigma-Aldrich, EUA) foram diluídos em tampão HEPES-Salina (140 $\mathrm{mM}$ de $\mathrm{NaCl}, 5 \mathrm{mM}$ de $\mathrm{KCl}, 1 \mathrm{mM}$ de $\mathrm{CaCl}_{2}, 1 \mathrm{mM}$ de $\mathrm{MgCl}_{2}, 10 \mathrm{mM}$ de HEPES - pH 7,4). Amostras contendo 2,5 $\mu \mathrm{g}$ do veneno ou da proteína P1 foram co-incubadas com esfingomielina em placas de 96 poços, durante 20 min a $37{ }^{\circ} \mathrm{C}$. Posteriormente, $10 \mu \mathrm{L}$ da mistura composta por colina oxidase $(1$ unidade $/ \mathrm{mL})$, peroxidase $(0,06$ unidade $/ \mathrm{mL})$ e $50 \mu \mathrm{M}$ de ácido 3-(4-hidroxil-fenil) propiônico, em HEPES, foram adicionados e a reação prosseguiu por mais 10 min a $37{ }^{\circ} \mathrm{C}$. Ao final, a colina liberada foi oxidada à betaína e peróxido de hidrogênio. A liberação da colina, com a conseqüente oxidação à betaína, foi acompanhada pela leitura a $\lambda 320 \mathrm{~nm}$ (excitação) e $\lambda 405 \mathrm{~nm}$ (emissão) no espectrofluorímetro VICTOR3 ${ }^{\mathrm{TM}}$ (Perkin-Elmer, EUA). A atividade esfingomielinásica das proteínas foi expressa em unidades arbitrárias de fluorescência, gerada pela liberação de colina. 


\subsubsection{Eritrócitos e soro humano normal}

Para a obtenção de eritrócitos, sangue humano foi coletado de doadores sadios em solução anticoagulante de Álsever (v/v) (114 mM de citrato, $27 \mathrm{mM}$ de glicose, $72 \mathrm{mM}$ de $\mathrm{NaCl}, \mathrm{pH}$ 6,1). A solução foi mantida até o momento do uso a $4{ }^{\circ} \mathrm{C}$. Para a obtenção de soro humano normal (SHN), o sangue foi coletado por punção venosa e refrigerado a $4{ }^{\circ} \mathrm{C}$ por $5 \mathrm{~h}$ para a retração do coágulo. Em seguida, o sangue foi centrifugado a $1500 \mathrm{rpm}$ por $10 \mathrm{~min}$ e a $4{ }^{\circ} \mathrm{C}$, sendo o soro coletado, aliquotado e estocado a $-80^{\circ} \mathrm{C}$.

\subsubsection{Atividade hemolítica}

Eritrócitos humanos foram lavados e ressuspendidos a $1 \%$ em tampão $\mathrm{VBS}^{++}$e incubados com 2,5, 5, 10 e $20 \mu \mathrm{g}$ do veneno ou da SMase P1 de L. intermedia, por $1 \mathrm{~h}$ a 37 ${ }^{\circ} \mathrm{C}$, sob agitação constante. Amostras controle foram incubadas apenas com tampão $\mathrm{VBS}^{++}$. Após a incubação, os eritrócitos foram lavados três vezes e ressuspendidos em $\mathrm{VBS}^{++}$. Cem microlitros dos eritrócitos, tratados ou não, foram incubados com $100 \mu \mathrm{L}$ de soro humano normal diluído 1:2 em $\mathrm{VBS}^{++}$. A lise total e o "background" da reação foram determinados pela incubação com água deionizada e $\mathrm{VBS}^{++}$, respectivamente. Após a incubação por $1 \mathrm{~h}$ a $37{ }^{\circ} \mathrm{C}$, as amostras foram centrifugadas, para a deposição de células não lisadas, os sobrenadantes coletados e a absorbância destes mensurada a $\lambda 414 \mathrm{~nm}$ em espectrofotômetro (Multiskan-EX, Labsystems, Finlândia). A atividade hemolítica foi calculada pela porcentagem de lise celular utilizando a seguinte fórmula: (Abs ${ }_{\text {amostra }}-\mathrm{Abs}_{\text {soro }}$ ) / ( $\mathrm{Abs}_{\mathrm{H} 2 \mathrm{O}-}-$ Abs vBS++) x 100.

\subsection{Células renais}

Células renais humanas, derivadas do túbulo proximal, da linhagem HK-2 (RYAN et al., 1994) foram cultivadas em uma mistura dos meios DMEM e RPMI, v/v, suplementada com $10 \%$ de Soro Fetal Bovino (Cultilab, Brasil), $1 \%$ penicilina/ estreptomicina e mantidas a $37{ }^{0} \mathrm{C} / 5 \% \mathrm{CO}_{2}$. 


\subsubsection{Tratamento das células $\mathrm{HK}-2$}

As células HK-2 foram tratadas com o veneno de L. intermedia ou com a SMase P1. Alternativamente, culturas tratadas com veneno/toxina foram ou não incubadas com tetraciclina ou galardina, inibidores de MMPs e de metaloproteases da família das adamlisinas, respectivamente, além dos inibidores específicos para ADAM 10 (GI254023) e ADAM 17 (GW280264). Após o tratamento, as culturas foram avaliadas quanto à viabilidade celular, morfologia, expressão de metaloproteases, alterações de marcadores de superfície e reguladores de Complemento, deposição de proteínas do Complemento e das esfingomielinases na superfície das células e morte celular.

\subsubsection{Análise da viabilidade celular}

A viabilidade celular foi determinada utilizando-se o ensaio de MTT (RYAN et al., 1994), com pequenas modificações. Para tanto, $5 \times 10^{4}$ células foram cultivadas em placas de 96 poços a $37^{\circ} \mathrm{C} / 5 \% \mathrm{CO}_{2}$ contendo $200 \mu \mathrm{L}$ de meio de cultura. Um dia após o plaqueamento, as células foram mantidas "overnight" em meio sem soro e depois incubadas com 2,5, 5 e 10 $\mu \mathrm{g}$ de P1 ou veneno bruto de L. intermedia e tratadas ou não com diferentes quantidades de tetraciclina. Células incubadas somente com salina foram utilizadas como controle positivo (100\% viáveis). Após os períodos de tratamentos (24, 48 e 72 h), os sobrenadantes foram coletados e as células incubadas com $60 \mu \mathrm{l}$ da solução de MTT ( $83 \mu \mathrm{g} / \mathrm{mL})$ em salina e as placas de cultura incubadas por $30 \mathrm{~min}$ a $37^{\circ} \mathrm{C} / 5 \% \mathrm{CO}_{2}$. Após o período de incubação, a solução de MTT foi substituída por $100 \mu \mathrm{L}$ de DMSO. A absorbância das amostras foi determinada em espectrofotômetro (Multiskan-EX, Labsystems, Finlândia) nos comprimentos de onda de $540 \mathrm{~nm}$ e $620 \mathrm{~nm}$. A viabilidade celular foi calculada pela fórmula:

[(D.O. da amostra ${ }_{(540-620 \mathrm{~nm})}$ - média da D.O. do corante ${ }_{(540-620 \mathrm{~nm})} /$ (média da D.O. do controle $_{(540-620 \mathrm{~nm})}$ - média da D.O. do corante $\left.\left.{ }_{(540-620 \mathrm{~nm})}\right)\right]$ x 100. 


\subsubsection{Zimografia}

Sobrenadantes das células HK-2 incubadas ou não com veneno/toxina, na presença ou não de tetraciclina foram submetidas à eletroforese vertical em gel de poliacrilamida e duodecil sulfato de sódio (SDS-PAGE), em condições não redutoras, na ausência de $\beta$ mercaptoetanol, como descrito por Laemmli (1970). Para a separação das proteínas e desenvolvimento da reação foram utilizados géis a $10 \%$ de acrilamida, acrescidos de 1 $\mathrm{mg} / \mathrm{mL}$ de gelatina, e para o empilhamento das amostras, géis a $5 \%$. A corrida foi realizada sob amperagem constante de $20 \mathrm{~mA}$ e a $4{ }^{\circ} \mathrm{C}$, no sistema Mighty Small (Hoefer Pharmacia Biotech, EUA). Após a corrida, os géis foram lavados por $1 \mathrm{~h}$ em 2,5 \% de Triton X-100 e incubados "overnight" a $37{ }^{\circ} \mathrm{C}$ em tampão substrato $(50 \mathrm{mM}$ de Tris- $\mathrm{HCl}, 200 \mathrm{mM}$ de $\mathrm{NaCl}$, $10 \mathrm{mM}$ de $\mathrm{CaCl}_{2}, 0.05 \%$ de Brij-35; pH 8.3). Após a incubação, os géis foram corados em Coomassie (40 \% de metanol, $10 \%$ de ácido acético e 0,2 \% de Comassie brilliant blue) por 30 min sob agitação, para a análise da presença de zonas claras que indicam digestão proteolítica (KLEINER, STETLER-STWENSON, 1994).

\subsubsection{Extração de RNA}

Células HK-2 foram cultivadas $\left(5 \times 10^{5}\right.$ células/ $\left.\mathrm{mL}\right)$ em placas de 24 poços e mantidas por 24 h em meio suplementado com SFB a $10 \%$. Após atingir a confluência entre 70-90 \%, as células foram mantidas "overnight" em meio sem SFB e, em seguida, incubadas com veneno $(12,5 \mu \mathrm{g})$ ou SMase P1 $(6,25 \mu \mathrm{g})$, na presença ou ausência de tetraciclina $(20 \mu \mathrm{g})$, e mantidas em estufa a $37{ }^{\circ} \mathrm{C} / 5 \% \mathrm{CO}_{2}$. Após $48 \mathrm{~h}$ do tratamento, o RNA das células foi extraído utilizando o kit RNAspin Mini RNA Isolation (GE Healthcare, EUA). Após a extração, o RNA foi aliquotado e estocado a $-80^{\circ} \mathrm{C}$ até o uso.

\subsubsection{RT- PCR}

As amostras de RNA foram submetidas à reação de transcrição reversa para a obtenção do cDNA. Assim, foram preparadas reações com $5 \mu \mathrm{L}$ de cada amostra de RNA e adicionado, para cada reação, 0,5 $\mu \mathrm{L}$ do primer anti-sense para MMP-2 ou MMP-9 (100 pmol). As amostras foram incubadas por $10 \mathrm{~min}$ a $65^{\circ} \mathrm{C}$ e, em seguida, foi adicionado $1 \mu \mathrm{L}$ do inibidor de RNase, $2 \mu \mathrm{L}$ de tampão RT, $1 \mu \mathrm{L}$ de dNTps e $1 \mu \mathrm{L}$ de M-MVL transcriptase 
reversa (New England Biolabs, EUA). A reação foi incubada a $42{ }^{\circ} \mathrm{C}$ por $1 \mathrm{~h}$, a $95{ }^{\circ} \mathrm{C}$ por 3 min e $4{ }^{\circ} \mathrm{C}$ por $2 \mathrm{~min}$. Adicionou-se $0,5 \mu \mathrm{L}$ de transcriptase reversa e a reação prosseguiu por $1 \mathrm{~h}$ a $42{ }^{\circ} \mathrm{C}$ e 5 min a $95^{\circ} \mathrm{C}$. O primer para $\beta$-actina foi utilizado como controle positivo da reação.

\subsubsection{PCR}

Amostras de cDNA $(5 \mu \mathrm{L})$ foram adicionadas à reação contendo $2,5 \mu \mathrm{L}$ de tampão [10X], $1 \mu \mathrm{L}$ de $\mathrm{MgCl}_{2}$ [50 mM], $1 \mu \mathrm{L}$ de dNTp [10 mM], 0,5 $\mu \mathrm{L}$ da enzima Taq [50U/mL] (Invitrogen, EUA), $1 \mu \mathrm{L}$ do primer sense (10 $\mathrm{mol}), 1 \mu \mathrm{L}$ do primer anti-sense (Tabela 1$)$ e o volume foi completado para $25 \mu \mathrm{L}$ com água deionizada. As amostras foram mantidas no termociclador Veriti (Applied Biosystems, EUA) a $95^{\circ} \mathrm{C}$ por 5 min. As amplificações foram realizadas em 40 ciclos: denaturação a $95^{\circ} \mathrm{C}$ por $1 \mathrm{~min}$, anelamento a $55^{\circ} \mathrm{C}$ por $30 \mathrm{~s}$ e síntese a $72{ }^{\circ} \mathrm{C}$ por 1 min. A extensão final da reação foi realizada em 1 ciclo a $72{ }^{\circ} \mathrm{C}$ por 5 min. Para determinar a expressão de MMP-2 e MMP-9, as amostras foram submetidas à eletroforese em gel de agarose a $2 \%$, contendo brometo de etídeo, e as bandas visualizadas e fotodocumentadas em transiluminador de luz ultravioleta.

Tabela 1 - Primers utilizados

\begin{tabular}{|c|c|c|}
\cline { 2 - 3 } \multicolumn{1}{c|}{} & Sense 5' $\mathbf{~ 3}$ & Antisense 5' $\mathbf{- 3}$ \\
\hline MMP-2 & CACCTATACCAAGAACTTCCG & CAGGAGGAGAAGGCTGTGTT \\
\hline MMP-9 & TGGACGATGCCTGCAACGTG & GTCGTGCGTGTCCAAAGGCA \\
\hline $\boldsymbol{\beta}$ actina & CCTTCCTGGGCATGGAGTC & GAGGAGCAATGATCTTGATCTTC \\
\hline
\end{tabular}

\subsubsection{Ensaio para detecção da Caspase-3}

Células HK-2 tratadas com veneno ou SMase P1 (10 $\mu \mathrm{g} / 10^{6}$ células) foram analisadas quanto a morte celular por apoptose utilizando-se o kit Caspase-3 (Roche Molecular Biochemicals, EUA) de acordo com as recomendações do fabricante. Após o tratamento, as células foram lisadas com tampão de lise e centrifugadas por $1 \mathrm{~min}, 20^{\circ} \mathrm{C}$ a $14.000 \mathrm{rpm}$. O sobrenadante foi removido e estocado a $-20^{\circ} \mathrm{C}$ até o momento da sua utilização. Uma placa de 
96 poços foi sensibilizada com anticorpo anti-Caspase-3 e incubada a $4{ }^{\circ} \mathrm{C}$ overnight. Após a incubação, realizou-se o bloqueio da placa com a solução de bloqueio por 30 min e a temperatura ambiente. A placa foi lavada por 3 vezes, com a solução de lavagem por 1 min cada, e $100 \mu \mathrm{L}$ das amostras experimentais foram adicionadas e a placa incubada por $1 \mathrm{~h}$ a 37 ${ }^{\circ} \mathrm{C}$ em câmara úmida. Após a incubação, a placa foi lavada por 3 vezes com a solução de lavagem e, em seguida, adicionada a solução subtrato (Ac-DEVD-AFC), sendo a placa incubada a $37^{\circ} \mathrm{C}$. A ativação da Caspase-3 foi acompanhada no espectrofluorímetro VICTOR $3^{\text {TM }}$ (Perkin-Elmer, EUA) pela leitura a $\lambda 405 \mathrm{~nm}$ (excitação) e $\lambda 535 \mathrm{~nm}$ (emissão), em intervalos de 30 min até $6 \mathrm{~h}$. A ativação da Caspase-3 foi determinada pela clivagem do substrato e liberação da fluorescência AFC (7-amido-4-trifluorometil-coumarin).

\subsubsection{Citometria de fluxo}

Amostras contendo $10^{6}$ células foram incubadas com $10 \mu \mathrm{g}$ da SMase P1 ou do veneno de L. intermedia por $2 \mathrm{~h}$ a $37^{\circ} \mathrm{C}$, sob agitação constante, na presença ou ausência de tetraciclina $(20 \mu \mathrm{g})$, galardina $(50 \mu \mathrm{M})$ ou inibidores para ADAM $10(\mathrm{GI} 254023,20 \mu \mathrm{M}) \mathrm{e}$ ADAM 17 (GW280264, $20 \mu \mathrm{M})$. Após a incubação, as células foram lavadas, ressuspensas em tampão de FACS e incubadas, durante 30 min a $4{ }^{\circ} \mathrm{C}$, com anticorpos específicos para os reguladores de superfície do complemento, i.e., CD59, DAF e MCP, para alguns outros marcadores de superfície, tais como MHC I (Major Histocompability Complex class 1), $\beta 2$ microglobulina $(\beta 2 \mathrm{M})$, EGFR (Receptor do Fator de Crescimento Epidermal), EPCR (Endothelial Protein C Receptor) ou com anticorpos anti-SMases D, para análise da ligação das esfingomielinases D à superfície das células. Após a incubação, as amostras foram lavadas, por três vezes, com tampão de FACS por 5 min a $1500 \mathrm{rpm}$ e a $4{ }^{\circ} \mathrm{C}$. As amostras foram, então, incubadas com anticorpos secundários específicos marcados com FITC por 30 min a $4{ }^{\circ} \mathrm{C}$ e, a seguir, lavadas, por três vezes, em tampão de FACS, por 5 min a 1500 rpm e a $4{ }^{\circ} \mathrm{C}$. As células foram fixadas em tampão de FACS contendo $1 \%$ de paraformaldeído e analisadas em citômetro de fluxo (FACScalibur, Becton Dickinson, CA, EUA). Como controle das reações, foram utilizadas células tratadas somente com tampão e submetidas à marcação acima descrita. 


\subsubsection{Ação do Complemento sobre células HK-2}

\subsubsection{Morte celular mediada por Complemento}

Células HK-2, tratadas ou não com veneno de L. intermedia ou proteína recombinante $\mathrm{P} 1\left(10 \mu \mathrm{g} / 10^{6}\right.$ células), foram incubadas por $2 \mathrm{~h}$ a $37^{\circ} \mathrm{C}$ sob agitação constante. As células foram incubadas com $100 \mu \mathrm{L}$ de SHN, como fonte de complemento, ou SH inativado (SH

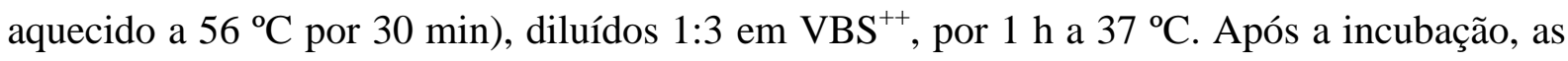
amostras foram lavadas três vezes com tampão $\mathrm{VBS}^{++}$a $1500 \mathrm{rpm}, 4^{\circ} \mathrm{C}$ por 5 min. Para analisar a morte celular por ação do complemento, as células foram marcadas com iodeto de propídeo e analisadas por citometria de fluxo.

\subsubsection{Deposição de componentes/ reguladores do Complemento}

Amostras contendo $10^{6}$ células foram incubadas com $10 \mu \mathrm{g}$ da SMase P1 ou do veneno de L. intermedia por $2 \mathrm{~h}$ a $37^{\circ} \mathrm{C}$, sob agitação constante. Após a incubação, as amostras foram lavadas três vezes com tampão $\mathrm{VBS}^{++}$a $1500 \mathrm{rpm}$, por 5 min e a $4{ }^{\circ} \mathrm{C}$ e incubadas com soro humano depletado do componente $\mathrm{C} 8$ na diluição de $1: 3$ por $1 \mathrm{~h}$ a $37^{\circ} \mathrm{C}$. Após a incubação, as amostras foram lavadas três vezes com tampão de FACS a 1500 rpm, 4 ${ }^{\circ} \mathrm{C}$ por 5 min e foram incubadas, por 30 min e a $4{ }^{\circ} \mathrm{C}$, com anticorpos específicos para os componentes $\mathrm{C} 1 \mathrm{q}, \mathrm{C} 3, \mathrm{C} 4$, fator $\mathrm{B}$, properdina e $\mathrm{MBL}$; para os reguladores solúveis do Complemento fator $\mathrm{H}$ e C4bp, e para as pentraxinas CRP e SAP. Após a incubação, as células foram lavadas, novamente, por três vezes com tampão de FACS a $1500 \mathrm{rpm}, 4^{\circ} \mathrm{C}$ por 5 min e incubadas com anticorpos secundários específicos marcados com FITC, por 30 min e a $4{ }^{\circ} \mathrm{C}$. A seguir, as amostras foram lavadas por três vezes em tampão de FACS, por 5 min a 1500 rpm e a $4{ }^{\circ} \mathrm{C}$, sendo as células fixadas em tampão de FACS contendo $1 \%$ de paraformaldeído e analisadas em citômetro de fluxo (FACScalibur, Becton Dickinson, CA, EUA). Como controles das reações, foram utilizadas células tratadas com tampão, incubadas ou não com complemento, e submetidas à marcação, como acima descrito. 


\subsubsection{Análise da ação de inibidores sobre a clivagem de MCP por Western Blot}

Amostras contendo $10^{6}$ células foram incubadas com $10 \mu \mathrm{g}$ do veneno de $L$. intermedia ou da SMase P1 por $2 \mathrm{~h}$ a $37^{\circ} \mathrm{C}$, sob agitação constante, na presença ou ausência da galardina $(50 \mu \mathrm{M})$ ou tetraciclina $(20 \mu \mathrm{g} / \mathrm{mL})$. Após a incubação, as células foram centrifugadas a $1500 \mathrm{rpm}, 4{ }^{\circ} \mathrm{C}$ por 15 min. O pellet celular foi solubilizado em tampão de corrida em condições não redutoras e estocado a $-20{ }^{\circ} \mathrm{C}$ até o momento do uso. $\mathrm{O}$ conteúdo protéico do sobrenadante foi determinado pelo método de Lowry e estocado a $-20{ }^{\circ} \mathrm{C}$. As amostras foram submetidas à eletroforese como descrito no item 5.1. Após a corrida, os géis foram eletrotransferidos para matrizes de nitrocelulose, segundo o método descrito por Towbin et al. (1979). As membranas foram bloqueadas com PBS contendo BSA $5 \%$ por $4 \mathrm{~h}$ a temperatura ambiente e, em seguida incubadas com anticorpo anti-MCP $(10 \mu \mathrm{g} / \mathrm{ml}) \mathrm{em}$ PBS/BSA $0,1 \%$ por $1 \mathrm{~h}$, à temperatura ambiente. Decorrido esse período, as membranas foram lavadas, por três vezes com PBS/ Tween-20 0,05\% por 5 min, e incubadas com conjugado específico marcado com fosfatase alcalina por $1 \mathrm{~h}$ à temperatura ambiente. A seguir, as membranas foram novamente lavadas, três vezes com PBS/Tween-20 0,05\% por 5 min, e a reação foi revelada pela adição do substrato NBT/ BCIP.

\subsection{Análise Estatística}

Os resultados foram expressos como a média dos valores $\pm \mathrm{SD}$. A diferença entre os grupos foi determinada estatisticamente pelo teste $t$ 'Students, utilizando o programa GraphPrism. Valores para $p \leq 0,05$ foram considerados estatisticamente significantes. 


\section{RESULTADOS}

\subsection{Purificação da SMase D recombinante P1 de $L$. intermedia}

O gene que codifica para a proteína P1 foi isolado da glândula de veneno da aranha $L$. intermedia e clonado no vetor de expressão pRSET-B (TAMBOURGI et al., 2004). A expressão protéica foi realizada utilizando-se a bactéria $E$. coli BL21 na presença de $10 \mathrm{mM}$ de IPTG. As bactérias foram lisadas por choque térmico, o sobrenadante foi fracionado por cromatografia de afinidade e a proteína recombinante eluída em tampão fosfato, contendo 80 $\mathrm{mM}$ de imidazol. As amostras das lavagens e da proteína eluída foram coletadas e submetidas à eletroforese em gel de SDS-PAGE, sob condições redutoras, sendo as bandas reveladas por impregnação pela prata. A Figura 5 mostra que a SMase D recombinante P1 foi expressa e purificada com sucesso. A proteína se apresenta como uma única banda de peso molecular ao redor de $37 \mathrm{kDa}$, sendo $3 \mathrm{kDa}$ correspondentes à inserção da cauda de histidina na porção N-

terminal, somada aos sítios de reconhecimento para o anticorpo anti-X press $^{\mathrm{TM}}$ e para a enzima enteroquinase. 
Figura 5 - Purificação da SMase P1. Análise por SDS-PAGE da purificação da toxina recombinante $\mathrm{P} 1$ de $L$. intermedia. O sobrenadante da lise das bactérias $E$. coli BL21, transformadas com o vetor pRSET contendo o cDNA da toxina P1 cuja expressão foi induzida por IPTG, foi submetido à cromatografia utilizando a coluna ProBond ${ }^{\mathrm{TM}}$ Nickel-Chelating. A coluna foi lavada com os tampões "binding", "wash" e imidazol $60 \mathrm{mM}$, sendo a proteína recombinante eluída com imidazol 0,8 M. As amostras coletadas foram separadas em SDS-PAGE (12\%), sob condição redutora, o qual foi corado por impregnação pela prata.

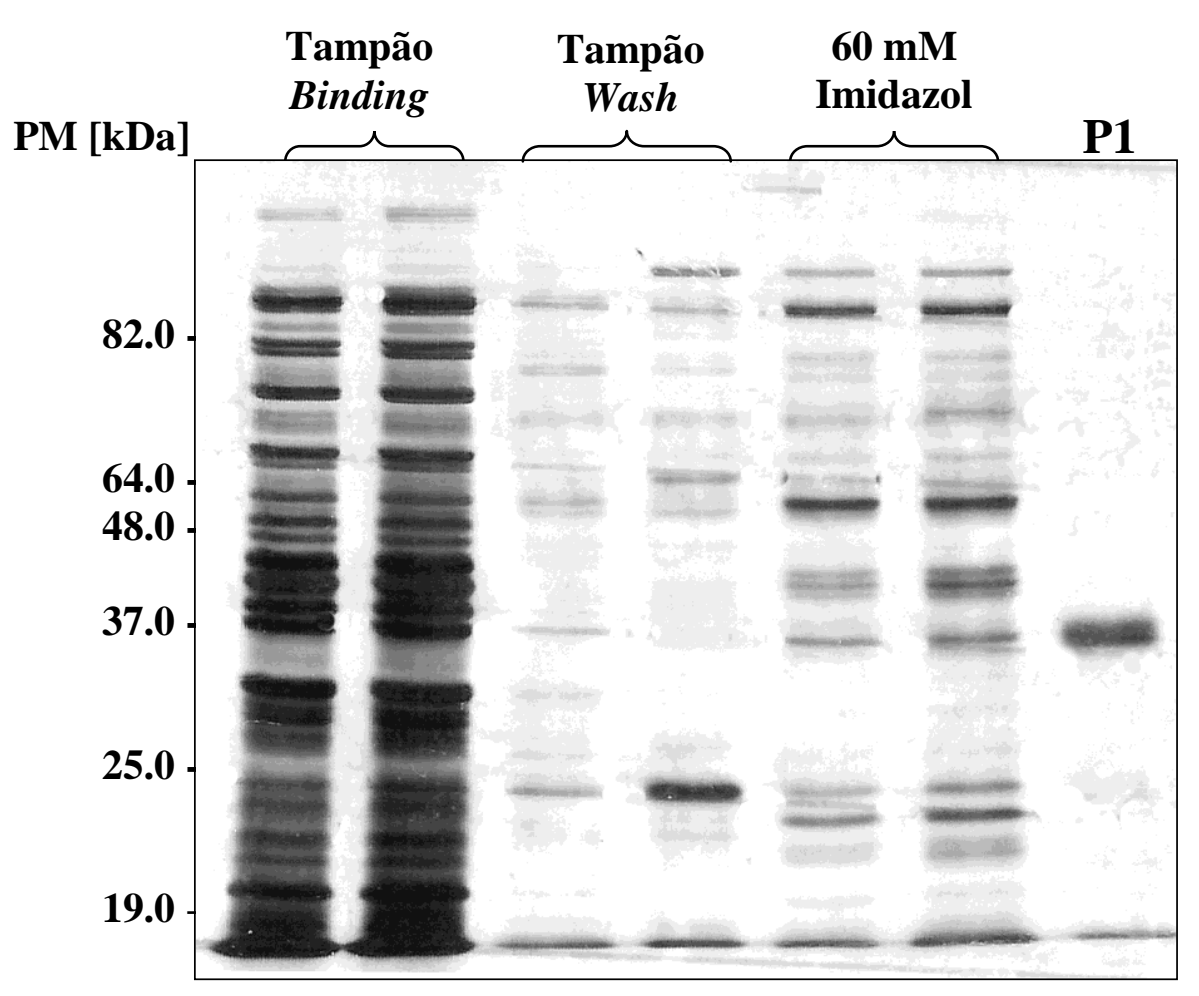




\subsection{Análise das atividades funcionais da SMase D recombinante $P 1$ e do veneno de $L$. intermedia}

Para avaliar a funcionalidade do veneno bruto e da proteína recombinante P1 de $L$. intermedia foram realizados ensaios para a determinação das atividades esfingomielinásica e indutora de hemólise dependente de complemento.

A atividade esfingomielinásica foi determinada pelo método de Tokumura et al. (2002). Para o ensaio foi utilizado $2,5 \mu \mathrm{g}$ de cada amostra, as quais foram incubadas com o substrato a $37^{\circ} \mathrm{C}$ por $30 \mathrm{~min}$. Os resultados apresentados na Figura 6 mostram que tanto o veneno, quanto a proteína recombinante $\mathrm{P} 1$ de $L$. intermedia, foram capazes de hidrolisar a esfingomielina, sendo P1 mais ativa que o veneno total.

Para avaliar se a proteína purificada era capaz de induzir hemólise dependente de Complemento, eritrócitos humanos foram incubados com 2,5 $\mu \mathrm{g}$ de veneno ou P1 e a seguir com tampão, como controle, ou SHN, como fonte de Complemento. A Figura 7 mostra que ambos, o veneno e a toxina, foram capazes de induzir lise dos eritrócitos, na presença de Complemento e que a concentração utilizada foi eficiente em promover cerca de $70 \%$ de lise. Eritrócitos pré-incubados com veneno ou P1 e a seguir com tampão, na ausência de SHN, não sofreram lise. 
Figura 6 - Hidrólise da esfingomielina. Amostras de esfingomielina foram incubadas com $2,5 \mu \mathrm{g}$ de veneno ou da SMase P1 de L. intermedia por 20 min e a $37^{\circ} \mathrm{C}$. A liberação de colina, com conseqüente oxidação à betaína e $\mathrm{H}_{2} \mathrm{O}_{2}$, foi determinada em fluorímetro e a hidrólise expressa em unidades arbitrárias de fluorescência.

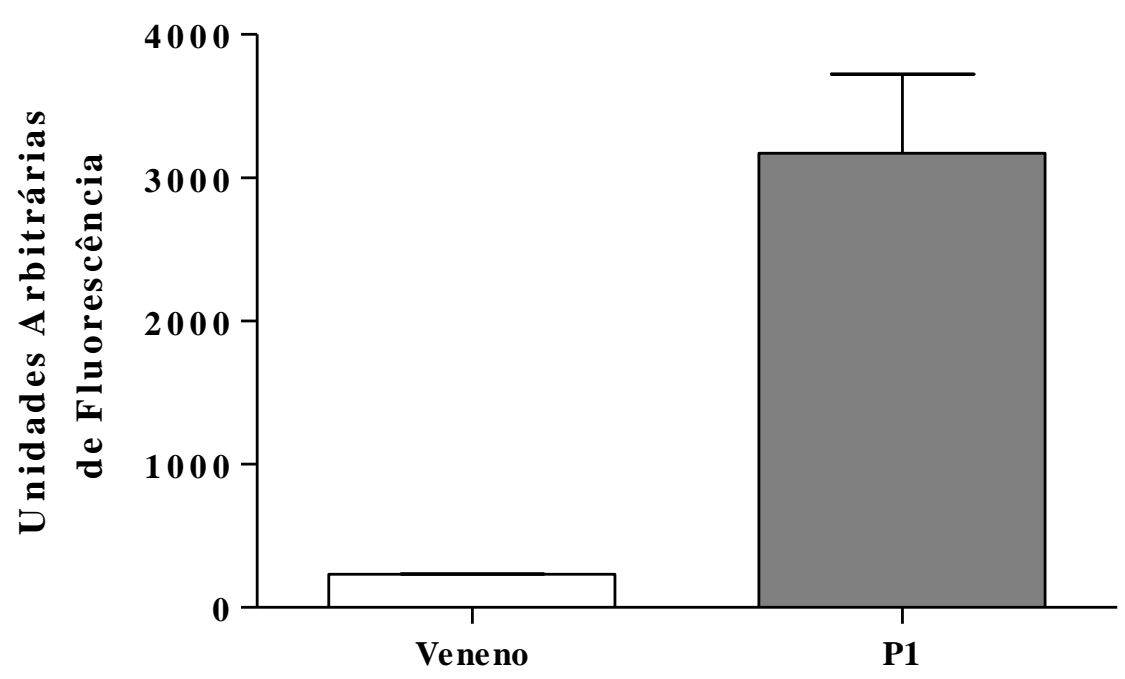


Figura 7- Ensaio hemolítico. Amostras do veneno e da toxina P1 $(2,5 \mu \mathrm{g})$ foram incubadas com os eritrócitos e, posteriormente, com soro humano normal por $1 \mathrm{~h}$ a $37^{\circ} \mathrm{C}$. Após a incubação, as células foram centrifugadas e o sobrenadante foi submetido à leitura em espectrofotômetro a $\lambda 414 \mathrm{~nm}$. A atividade hemolítica foi expressa pela porcentagem de lise

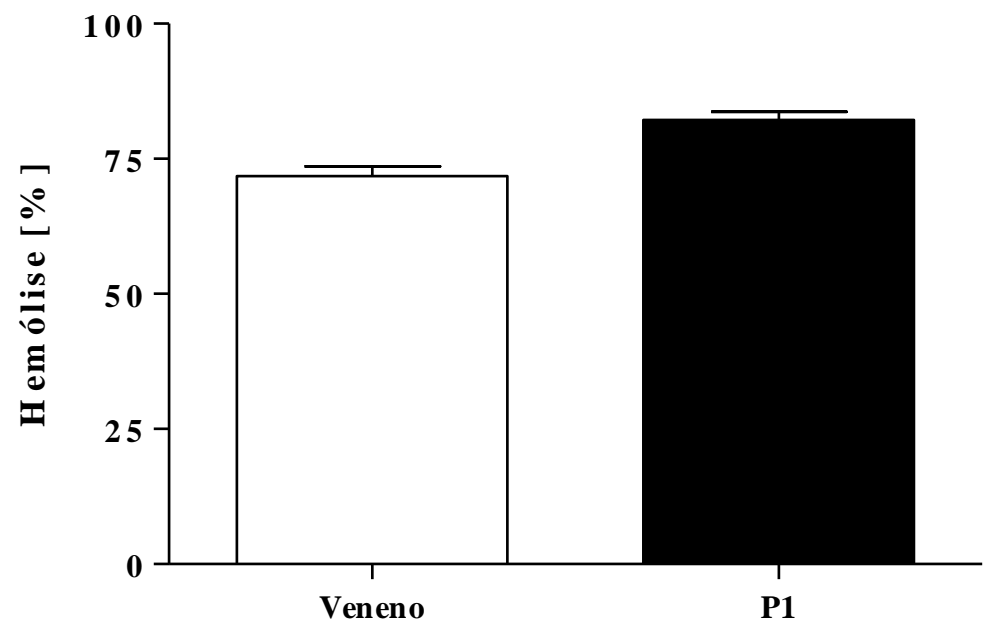




\subsection{Análise da ação do veneno e da esfingomielinase P1 sobre a viabilidade celular}

Para avaliar a toxicidade do veneno e da esfingomielinase P1 de L. intermedia, células renais da linhagem HK-2 foram incubadas, em duplicatas, com 2,5, 5 e $10 \mu \mathrm{g}$ do veneno ou da toxina e a viabilidade celular foi analisada, pelo método de MTT, nos períodos de 24, 48 e 72 h. Como controle da reação, as células foram incubadas apenas com meio de cultura incompleto. A Figura 8 mostra que o veneno, nas concentrações utilizadas, foi capaz de induzir uma significativa perda de viabilidade celular, após $72 \mathrm{~h}$ do tratamento. A esfingomielinase recombinante P1 mostrou ser mais potente do que o veneno na indução de morte, nas quantidades de 5 e $10 \mu \mathrm{g}$ e em todos os tempos ensaiados. Após 48 h, amostras de 2,5 $\mu \mathrm{g}$ da SMase D P1 foram também capazes de causar diminuição significativa de viabilidade celular. Às $72 \mathrm{~h}$ do tratamento, P1 induziu $100 \%$ de morte celular em todas as quantidades testadas. 
Figura 8 - Viabilidade das células HK-2 tratadas com veneno ou toxina recombinante P1 de $\boldsymbol{L}$. intermedia. Células HK-2 foram tratadas com diferentes quantidades de veneno [A] ou SMase P1 [B]. Como controle foram analisadas células tratadas com meio de cultura. A viabilidade celular foi avaliada após 24,48 e $72 \mathrm{~h}$ dos tratamentos, pelo método de MTT, e expressa em porcentagem. Os resultados representam a média das duplicatas. A análise estatística mostra diferenças entre as células tratadas somente com tampão e aquelas tratadas com veneno ou P1 $(* \mathrm{p} \leq 0,05)$.

A
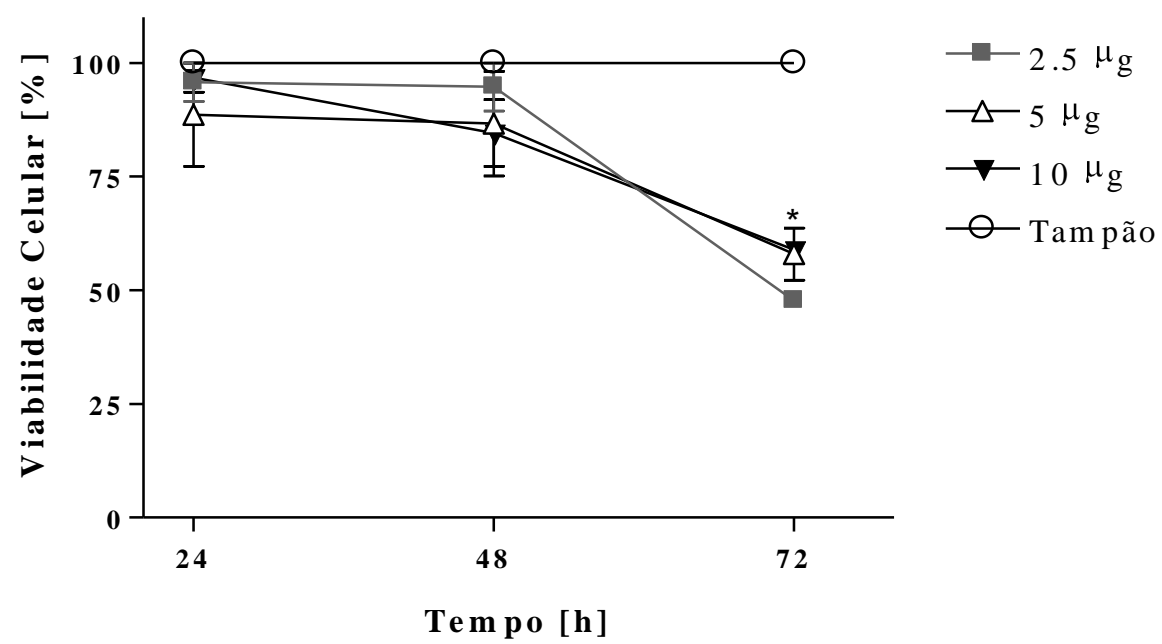

B
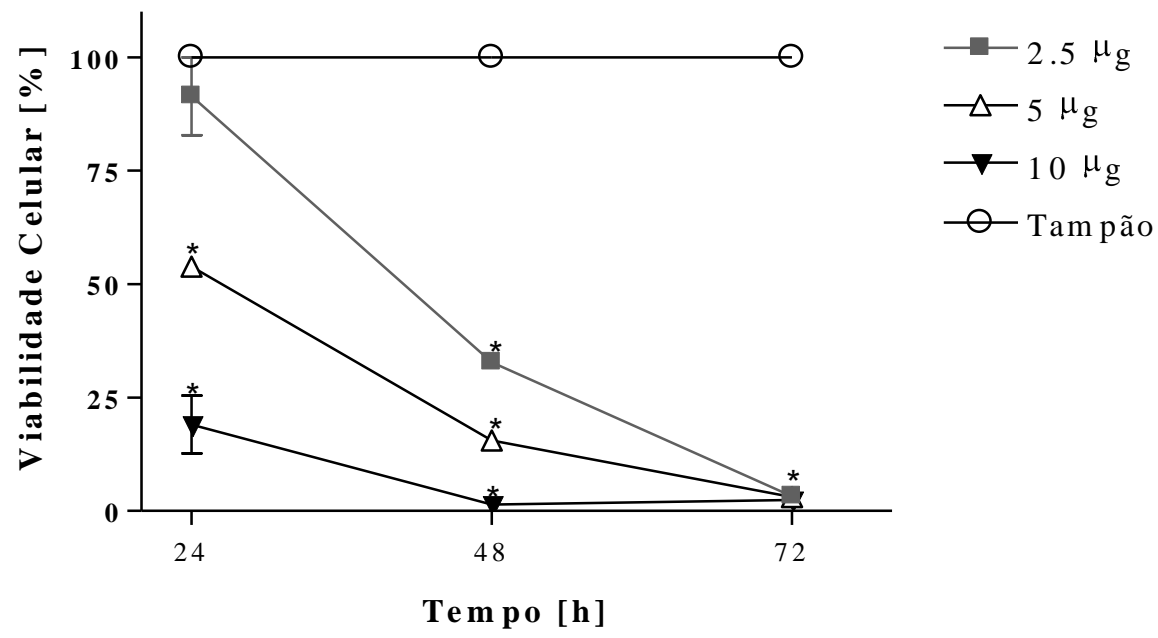
4.4 Ativação da Caspase-3 no processo de morte celular induzida por veneno e SMase D P1 de $L$. intermedia

Para verificar se a perda de viabilidade celular induzida pelo veneno e pela SMase D P1 ocorria pelo processo de apoptose, células renais foram incubadas por 2 horas com tampão, veneno ou P1 (10 $\mu \mathrm{g} / 10^{6}$ células) e analisadas quanto à ativação da Caspase-3. A leitura dos ensaios foi feita durante 6 horas, com intervalos de 30 minutos. A Figura 9 mostra que tanto o veneno de $L$. intermedia quanto P1 foram capazes de causar um aumento significativo de ativação de Caspase-3 em células HK-2. 
Figura 9 - Ativação da Caspase-3. Células renais humanas $\left(10^{6}\right)$ foram incubadas com $10 \mu \mathrm{g}$ do veneno [A] ou SMase P1 [B] por 2 horas e a ativação da Caspase-3 foi analisada durante 6 horas, com intervalos de $30 \mathrm{~min}$. Todos os ensaios foram realizados em duplicata. *Valores considerados estatisticamente significativos para $p<0,05$ quando comparados ao controle negativo (células tratadas com tampão).

\section{A}

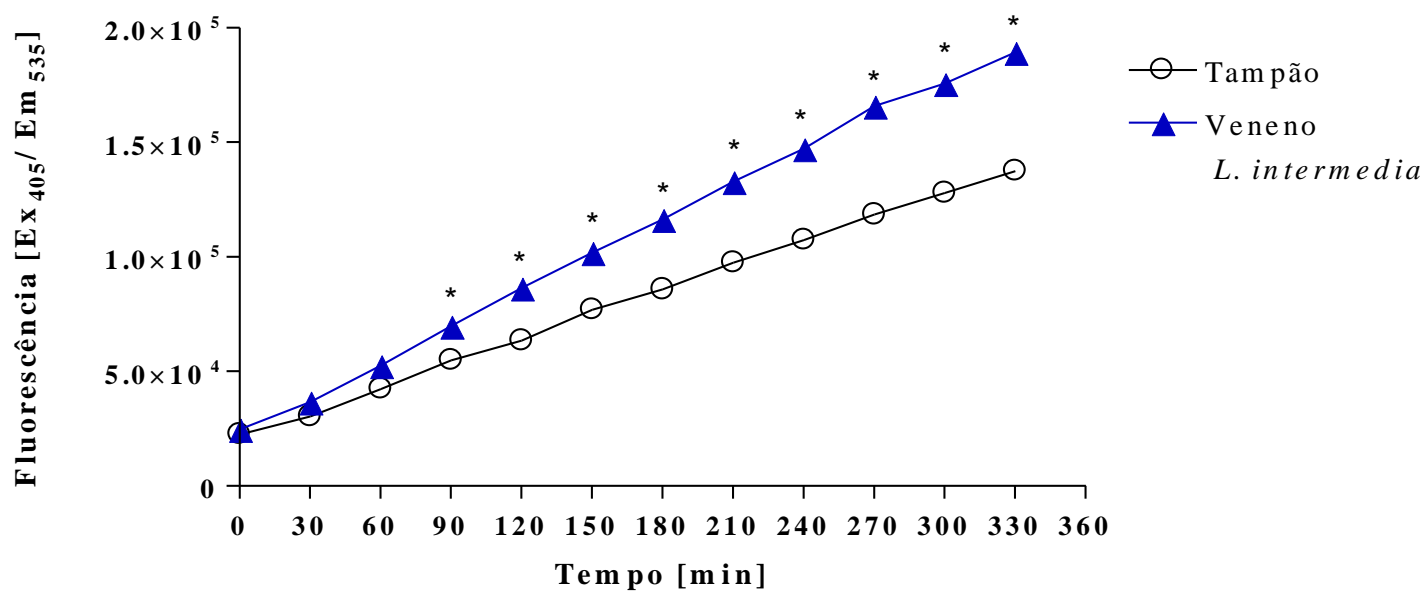

\section{B}

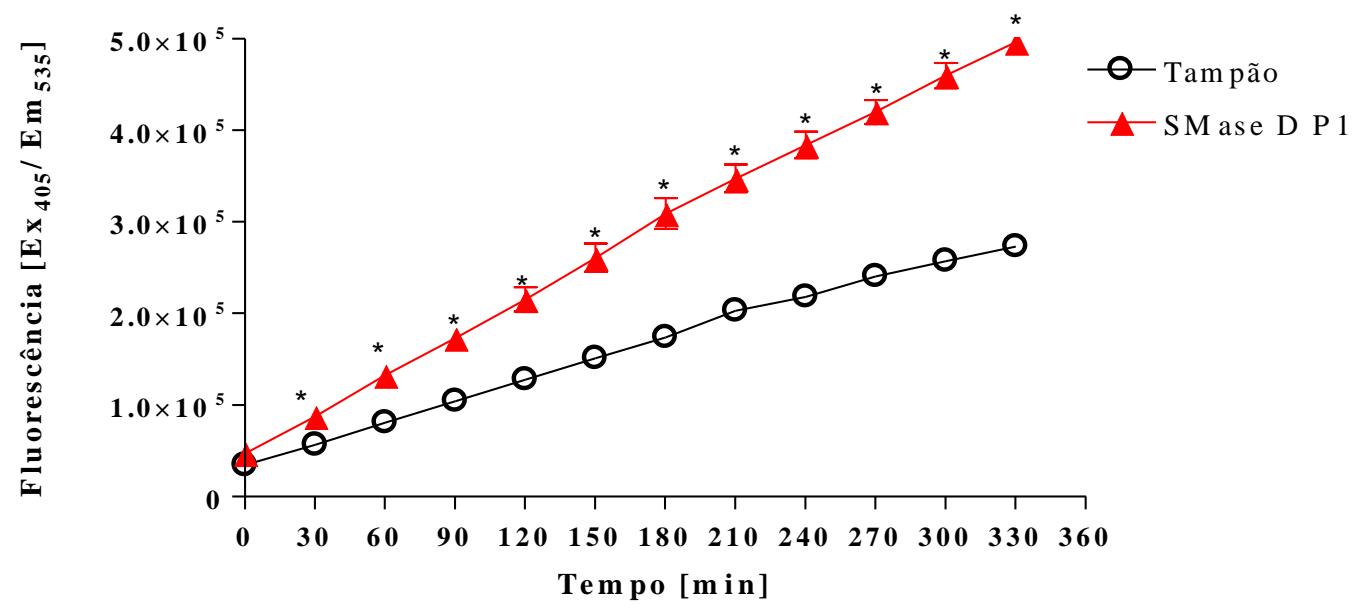




\subsection{Análise da atividade gelatinolítica, induzida pelo veneno e SMase D P1 de $L$. intermedia, por zimografia}

Estudos anteriores mostraram que tanto o veneno, quanto as SMases D, induzem a expressão das metaloproteases MMP-2 e MMP-9 em queratinócitos humanos, sendo estas importantes elementos para a gênese do loxoscelismo cutâneo (TAMBOURGI et al., 2005; PAIXÃO-CAVALCANTE et al., 2006, 2007). Para analisar o envolvimento destas metaloproteases no loxoscelismo sistêmico, amostras dos sobrenadantes das células HK-2, tratadas com tampão ou com diferentes quantidades do veneno ou da toxina recombinante, foram coletadas nos tempos de 24, 48 e 72 h e submetidas à zimografia.

A Figura 10 mostra que células tratadas com 2,5 e $5 \mu \mathrm{g}$ da SMase P1 apresentaram aumento na expressão/secreção de MMP-9 ativa, proteína com peso molecular ao redor de 90 $\mathrm{kDa}$, em todos os tempos de tratamento, quando comparada àquelas incubadas somente com tampão. Células tratadas com o veneno apresentaram maior expressão/secreção da MMP-9, após 48 e 72 h. Nas amostras de sobrenadantes, coletadas após 72 h do tratamento com veneno ou SMase P1, foi observado aumento na expressão e/ou secreção de proteínas com $\mathrm{Mr}$ ao redor de $72 \mathrm{kDa}$ correspondente à MMP-2. 
Figura 10 - Indução da expressão/secreção de gelatinases em células HK-2 pelo veneno e pela SMase D P1 de L. intermedia. Amostras dos sobrenadantes das culturas de células renais HK-2 incubadas por $24 \mathrm{~h} \mathrm{[A],} 48 \mathrm{~h}$ [B] e $72 \mathrm{~h} \mathrm{[C]}$ com meio (C), veneno $(\mathrm{V})$ ou SMase $\mathrm{D}(\mathrm{P} 1)$ nas quantidades de 2,5 e $5 \mu \mathrm{g}$, foram submetidas à zimografia.

A
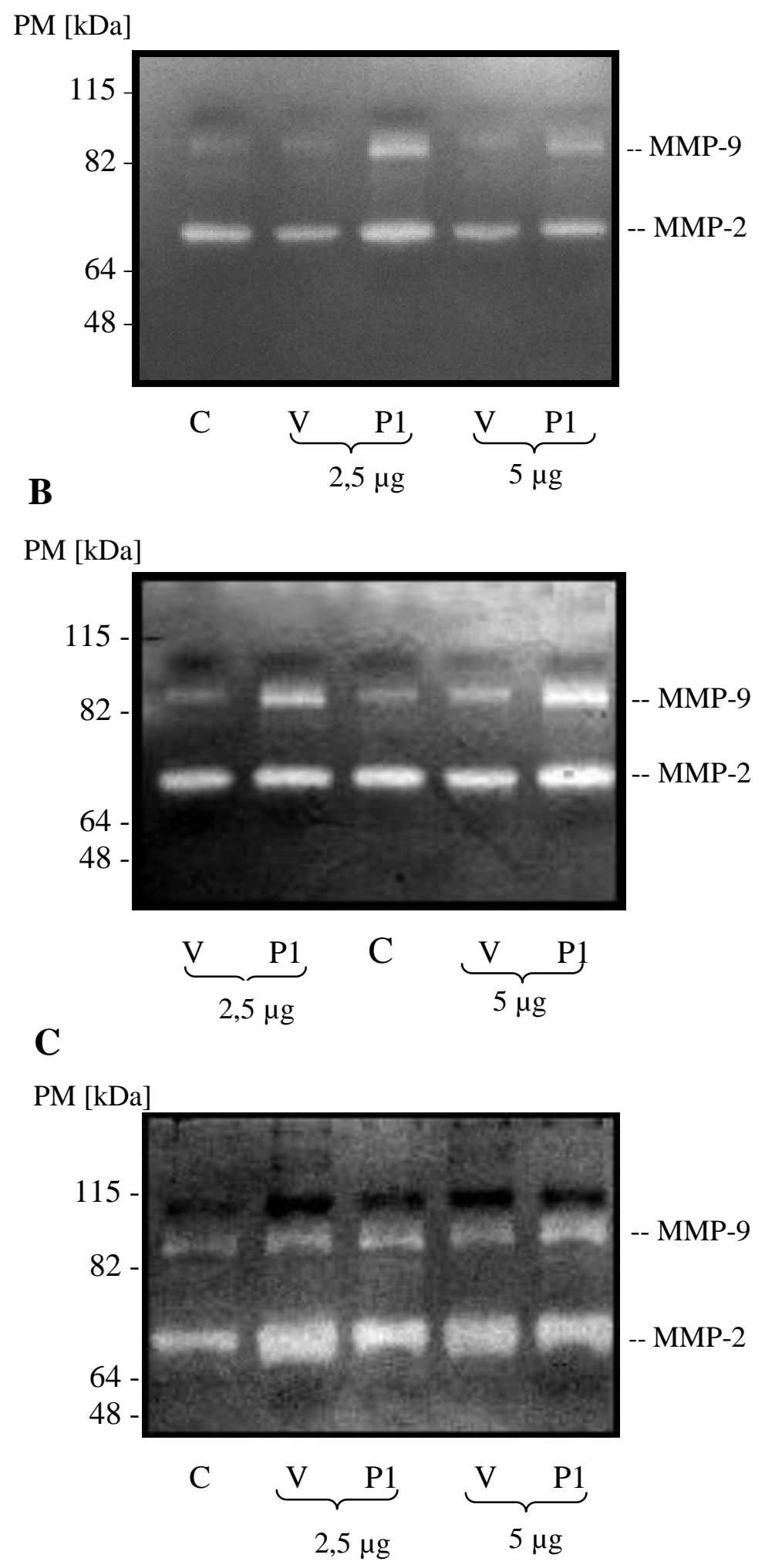


\subsection{Ação da tetraciclina sobre a expressão de MMPs e controle da morte celular}

Estudos realizados por Paixão-Cavalcante et al. (2007) demonstraram que o tratamento com tetraciclina era capaz de inibir a morte celular de queratinócitos humanos, induzida pelo veneno ou SMase P2 de L. intermedia e que tal inibição estava relacionada ao bloqueio da expressão de MMP-2 e MMP-9. Para avaliar se o tratamento com este inibidor poderia também prevenir a morte das células renais humanas, $5 \times 10^{4}$ células foram incubadas com diferentes quantidades de tetraciclina. A viabilidade celular foi determinada nos tempos de 24, 48 e $72 \mathrm{~h}$ pelo método de MTT. A Figura 11 mostra que a tetraciclina é tóxica para as células renais, causando perda de viabilidade celular, principalmente na concentração de 50 $\mu \mathrm{g}$ e após $72 \mathrm{~h}$ de incubação.

Considerando que às 24 e $48 \mathrm{~h}$ de incubação, $20 \mu \mathrm{g}$ de tetraciclina não provocou perda de viabilidade celular superior a $10 \%$ e que, neste período, a incubação das células HK-2 com $5 \mu \mathrm{g}$ da SMase P1 e veneno de L. intermedia causava morte significativa e ativação das MMPs, estabeleceu-se o tempo de 24 e 48 h de incubação para SMase P1 e veneno de $L$. intermedia respectivamente, a dose de $20 \mu \mathrm{g}$ de tetraciclina e o tratamento com $5 \mu \mathrm{g}$ de SMase P1 ou do veneno de L. intermedia, para se analisar o eventual efeito protetor deste inibidor sobre a morte celular induzida pela toxina e veneno de L. intermedia.

As Figuras 12 e 13 mostram que o tratamento com $20 \mu \mathrm{g}$ de tetraciclina causou redução significativa da morte celular induzida pelo veneno/SMase D. Tal inibição foi positivamente correlacionada com a diminuição significativa da expressão/secreção de MMP2 e MMP-9, como demonstrado no ensaio de zimografia e pela análise densitométrica dos géis. 
Figura 11 - Efeito tóxico da tetraciclina sobre a viabilidade das células HK-2. $5 \times 10^{4}$ células renais humanas foram incubadas com concentrações crescentes de tetraciclina e a viabilidade celular foi analisada às 24,48 e $72 \mathrm{~h}$, pelo método de MTT. Todos os ensaios foram realizados em duplicata.

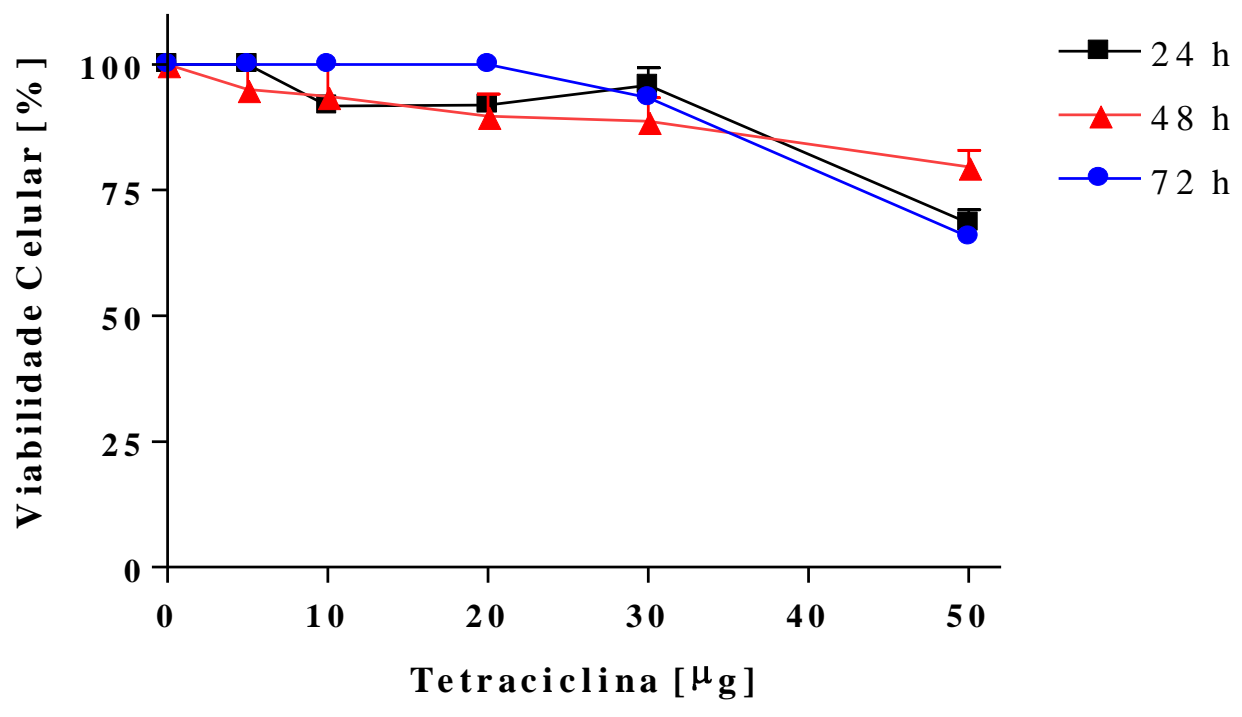


Figura 12 - Ação da tetraciclina no controle da morte celular e atividade gelatinolítica induzida pelo veneno. Células $\mathrm{HK}-2$ foram incubadas com $5 \mu \mathrm{g}$ do veneno de L. intermedia, tratadas ou não com tetraciclina sendo as análises realizadas às 48 h. [A] A viabilidade celular foi determinada pelo método de MTT. [B] Amostras dos sobrenadantes das células foram submetidas à zimografia e à análise por densitometria [C]. O ensaio foi realizado em duplicata e valores, para $p \leq 0,05$, foram considerados estatisticamente significantes em relação ao tratamento com veneno $(*)$.

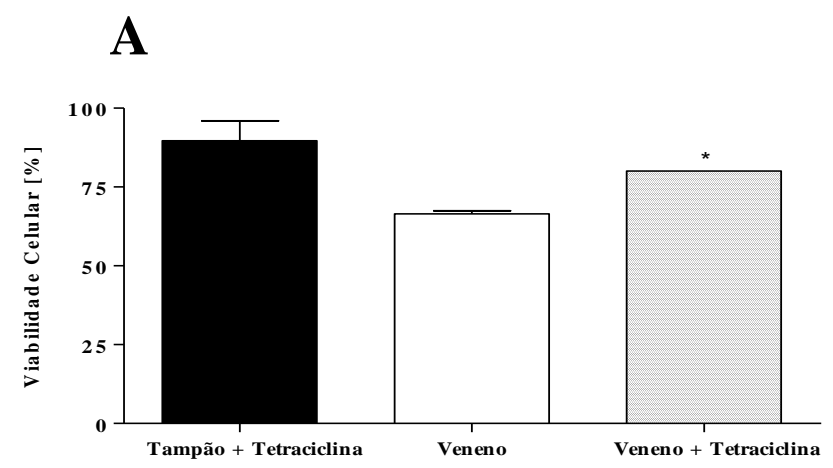

\section{B}

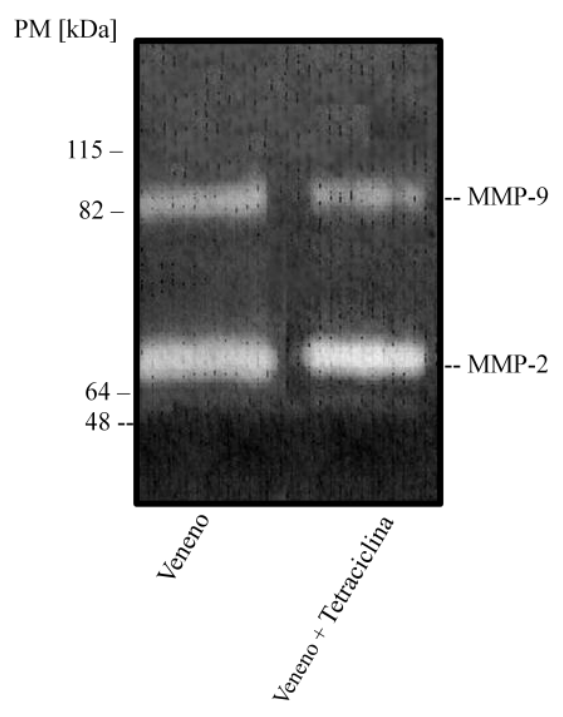

$\mathbf{C}$
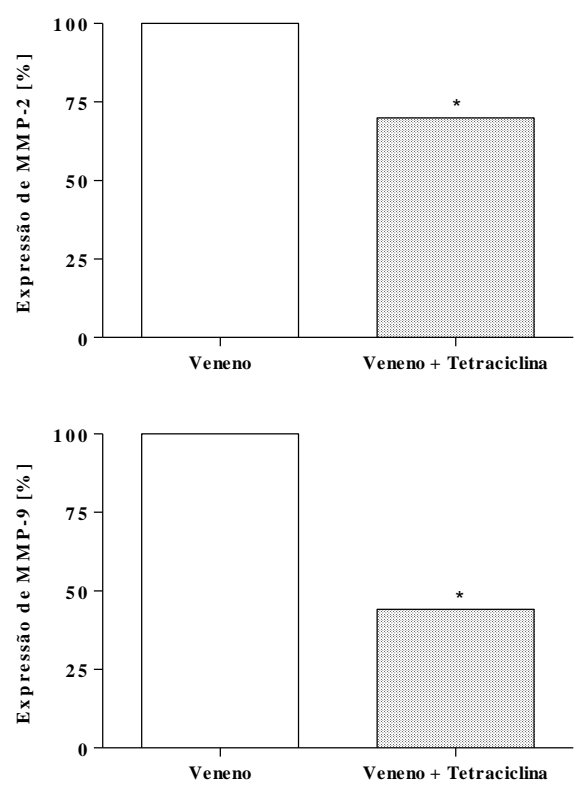
Figura 13 - Ação da tetraciclina no controle da morte celular e atividade gelatinolítica induzida pela SMase D P1. Células HK-2 foram incubadas com $5 \mu \mathrm{g}$ da SMase $\mathrm{D}$ P1, tratadas ou não com tetraciclina sendo as análises realizadas às $24 \mathrm{~h}$. [A] A viabilidade celular foi determinada pelo método de MTT. [B] Amostras dos sobrenadantes das células foram submetidas à zimografia e à análise por densitometria [C]. O ensaio foi realizado em duplicata e valores, para $p \leq 0,05$, foram considerados estatisticamente significantes em relação ao tratamento com $\mathrm{P} 1(*)$.

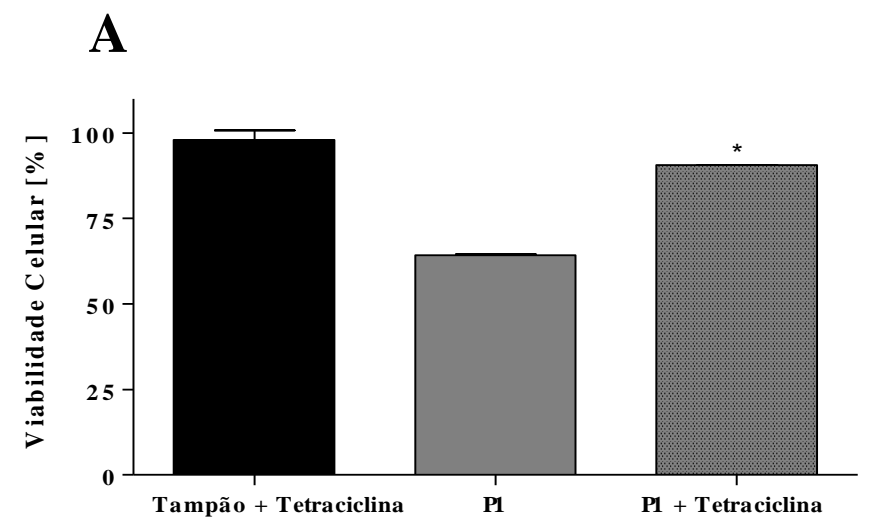

B

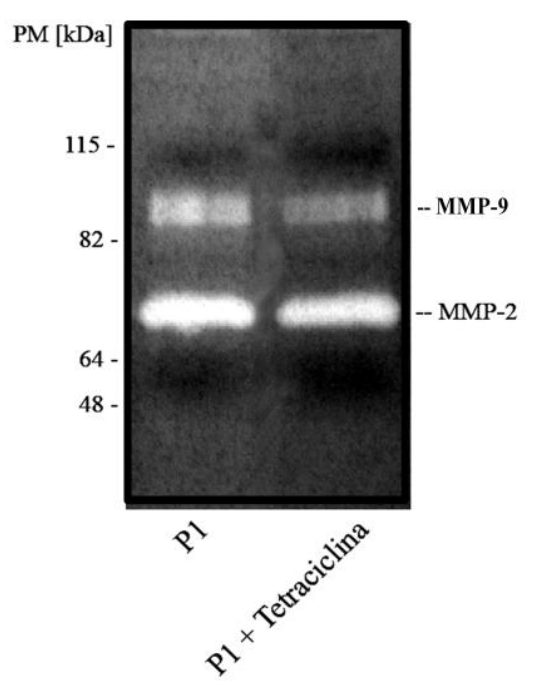

C
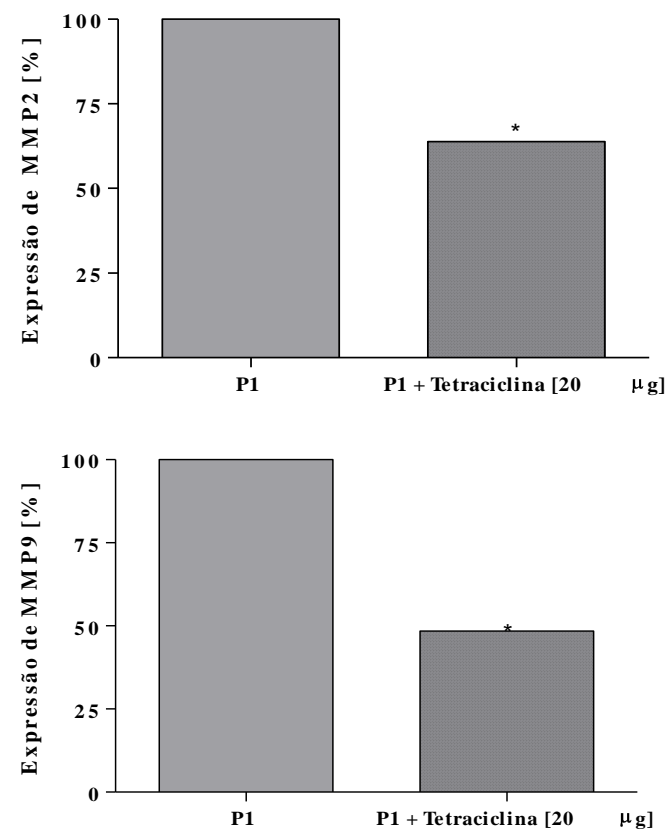


\subsection{Expressão de MMP-2 e MMP-9}

Como demonstrado nas Figuras 12 e 13, tanto o veneno quanto a SMase P1 de $L$. intermedia são capazes de induzir aumento na expressão e/ou secreção de MMPs. Para verificar se o aumento na detecção de MMPs, no sobrenadante das culturas das células HK-2, induzido pelo tratamento com veneno ou SMase D P1, era decorrente de uma maior secreção ou expressão dessas proteases, foram realizados ensaios de PCR. Além disso, foi também analisada a ação do tratamento da tetraciclina na expressão das gelatinases.

A Figura 14 mostra que células incubadas apenas com tetraciclina apresentam um aumento na expressão das MMPs quando comparada às células não tratadas, reforçando assim a toxicidade deste inibidor sobre as células renais HK-2. Células tratadas com veneno ou a SMase P1 apresentam um aumento na expressão tanto de MMP-2 quanto de MMP-9, quando comparada às células tratadas apenas com tampão ou tetraciclina. Tal expressão pode ser controlada em células tratadas com a tetraciclina, demonstrando a sua eficácia na inibição da expressão de MMP-2 e MMP-9. A expressão de $\beta$-actina, utilizada como controle, não foi afetada pelo tratamento com tetraciclina. A Figura 15 mostra a análise densitométrica da expressão das MMPs, cujos valores foram normalizados com base na expressão constitutiva da $\beta$-actina. 
Figura 14 - Expressão de MMP-2 e MMP-9. Amostras de RNA extraído de células renais, previamente incubadas com veneno (V) ou SMase P1 (P1), tratadas ou não com tetraciclina (tetra), foram analisadas às $48 \mathrm{~h}$, pelas técnicas de RT-PCR e PCR para determinação da expressão de MMP-2 e MMP-9. Células tratadas com tampão (T) e tetraciclina foram utilizadas como controle negativo. Como controle positivo foi analisada a expressão constitutiva da $\beta$-actina, utilizando primer específico.

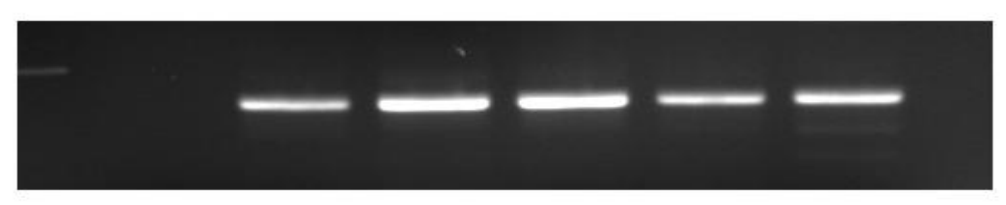

MMP-2

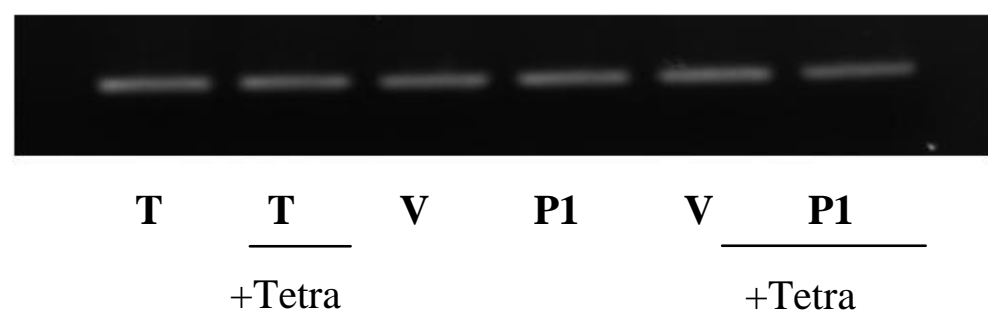

$\beta$-actina

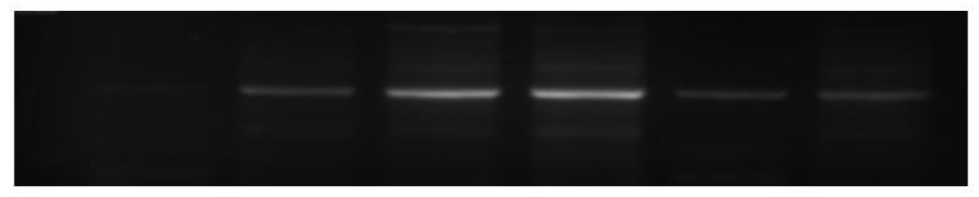

MMP-9

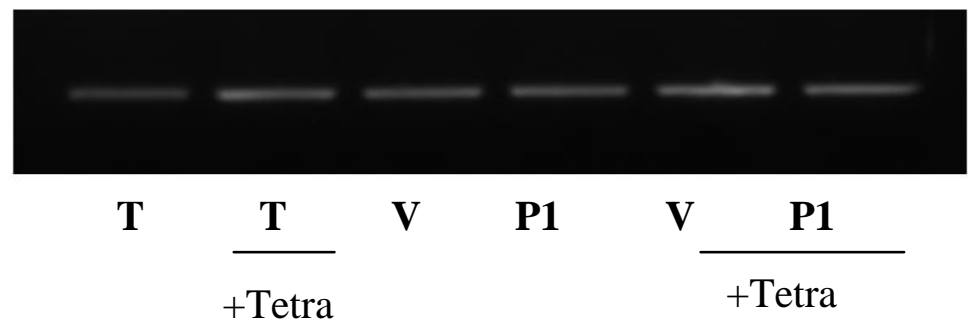

$\beta$ - actina 
Figura 15 - Análise densitométrica da expressão de MMP-2 e MMP-9. Os géis de agarose foram submetidos à densitometria. Os valores de D.O obtidos para as MMPs 2 ou 9 foram divididos pelos valores de D.O determinados para a $\beta$-actina, controle positivo da reação. Resultados foram expressos como a média das leituras de duplicatas. Valores para $\mathrm{p} \leq 0,05$ foram considerados estatisticamente significantes. *Veneno x Veneno + Tetraciclina, " SMase P1 x SMase P1 + Tetraciclina

M M P - 2

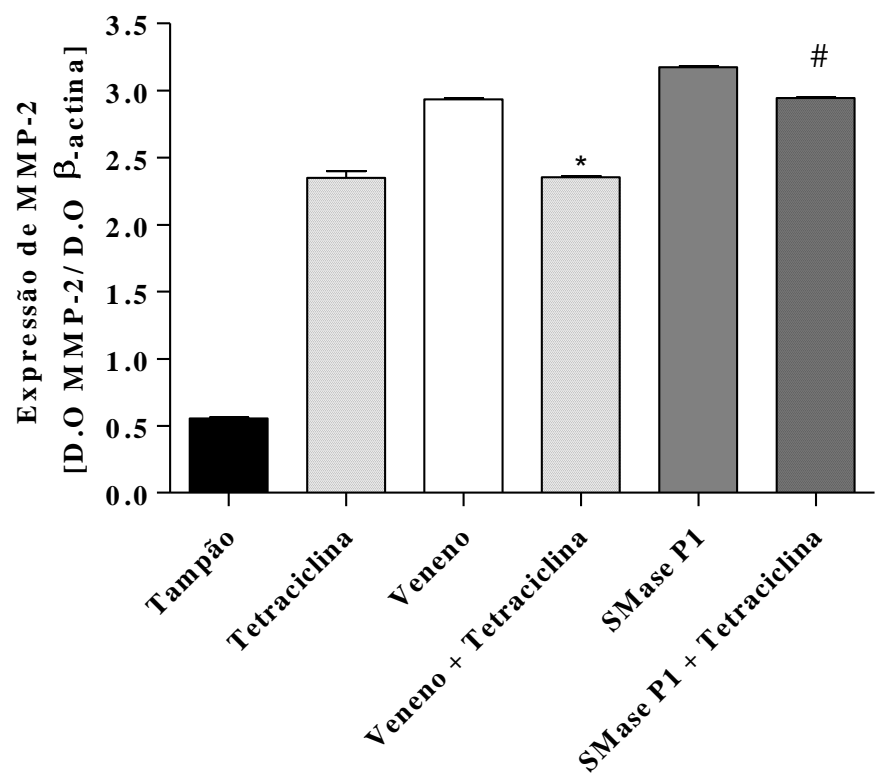

M M P -9

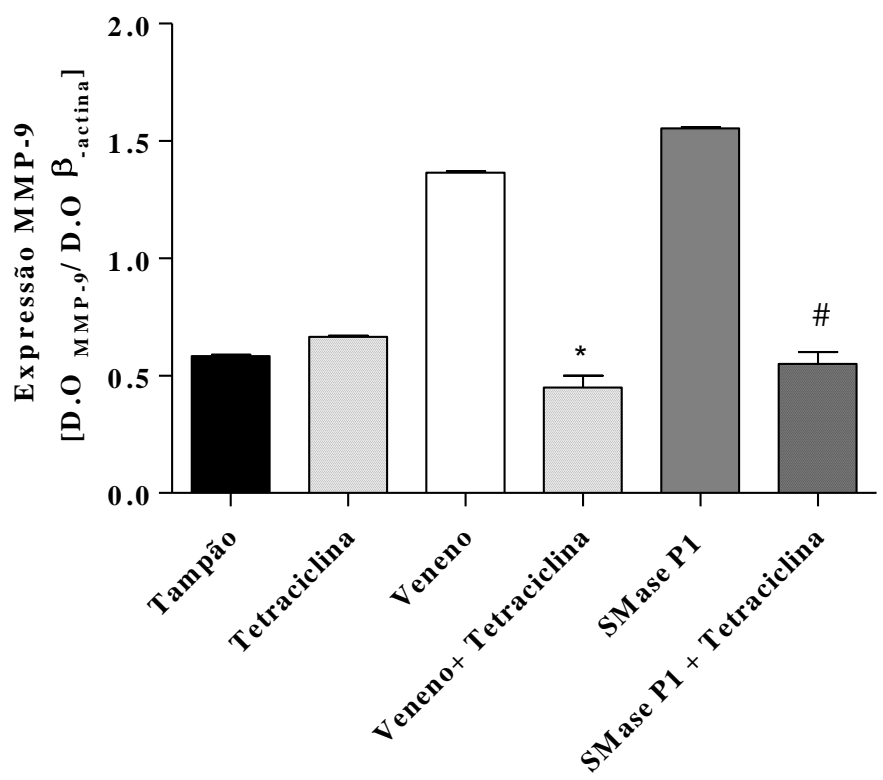


4.8 Ação do veneno e da SMase D P1 sobre os marcadores de superfície das células HK2

Para analisar a ação do veneno e da SMase P1 de L. intermedia sobre a expressão de proteínas de superfície, $10^{6}$ células HK-2 foram incubadas com $10 \mu \mathrm{g}$ do veneno ou da SMase $\mathrm{P} 1$, por $2 \mathrm{~h}$ a $37^{\circ} \mathrm{C}$. Após a incubação, as células foram tratadas com anticorpos contra os marcadores de superfície MHCI, $\beta 2 \mathrm{~m}$, EPCR e EGFR. A Figura 16 mostra que tanto o veneno quanto a SMase P1 induziram reduções significativas na expressão de MHCI, $\beta 2 \mathrm{~m}$, EPCR e EGFR. 
Figura 16 - Efeito do veneno e da SMase D P1 de $L$. intermedia sobre a expressão de moléculas de membrana, em células renais. Células HK-2 (10 células) foram incubadas com $10 \mu \mathrm{g}$ de veneno ou da SMase P1 ou com tampão (controle) e a superfície celular foi analisada, por citometria de fluxo, quanto à expressão de proteínas de membrana. Os resultados foram expressos como as médias das porcentagens de fluorescência determinadas em relação ao controle, em ensaios realizados em duplicatas $(* p<0,05)$.

M HCI

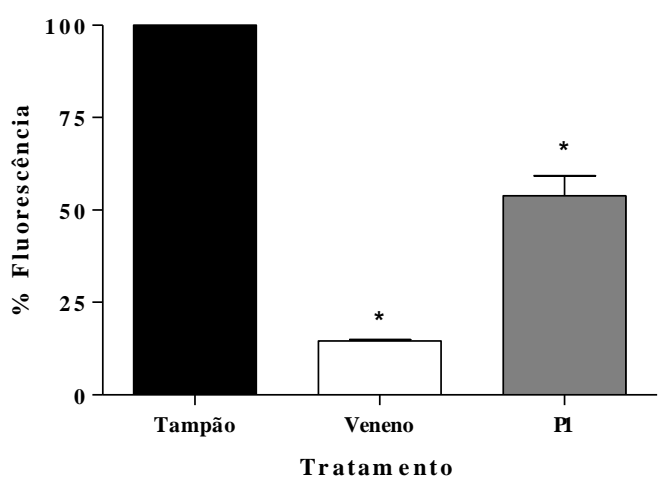

E P C R

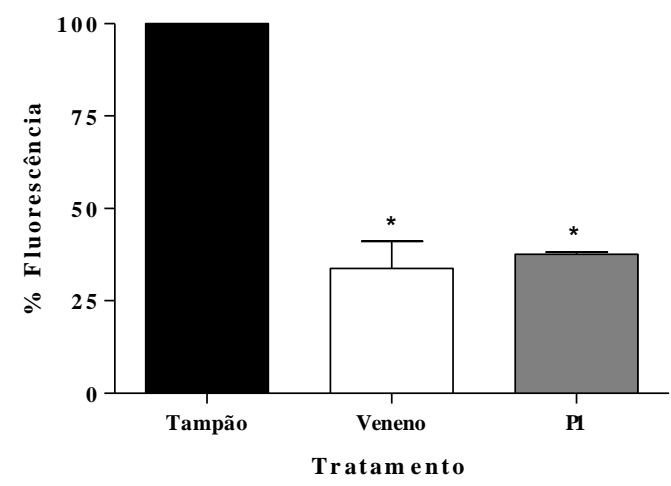

$\beta_{2}$-microglobulina

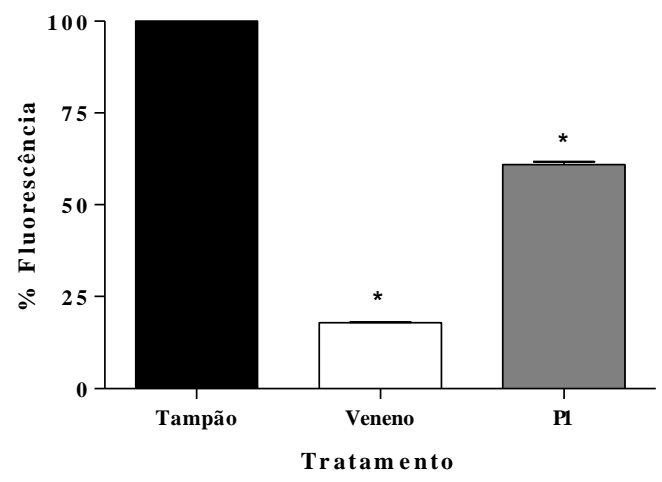

E G F R

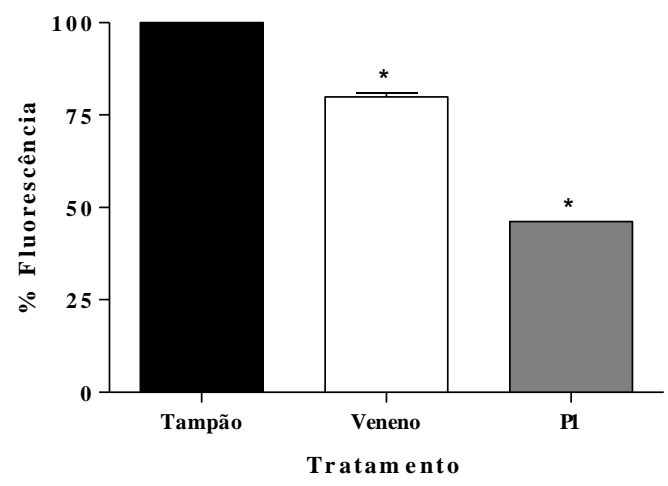


4.9 Efeito do veneno e da SMase P1 sobre os reguladores de membrana do Sistema Complemento em células renais

Amostras contendo $10^{6}$ células HK-2 foram incubadas com $10 \mu \mathrm{g}$ do veneno ou da SMase P1, por $2 \mathrm{~h}$ e a $37^{\circ} \mathrm{C}$. Após a incubação, as células foram tratadas com anticorpos contra os reguladores de superfície do complemento CR1, DAF, MCP e CD59. A Figura 17 mostra que tanto o veneno, quanto a SMase D P1, induziram reduções significativas na expressão de MCP, mas não na de DAF e CD59. A expressão de CR1 não pode ser detectada nesta linhagem celular (dados não mostrados). 
Figura 17 - Efeito do veneno e da SMase D P1 de $L$. intermedia sobre a expressão de reguladores do complemento em células renais. Células HK-2 (10 células) foram incubadas com $10 \mu \mathrm{g}$ do veneno ou da proteína P1 ou com tampão (controle) e a superfície celular foi analisada por citometria de fluxo, quanto à expressão de reguladores de complemento. Resultados foram expressos como as médias das porcentagens de fluorescência determinadas em relação ao controle, em experimentos realizados em duplicata.*Valores para $p<0,05$ foram considerados estatisticamente significantes, quando comparados aos do controle (células tratadas com tampão).
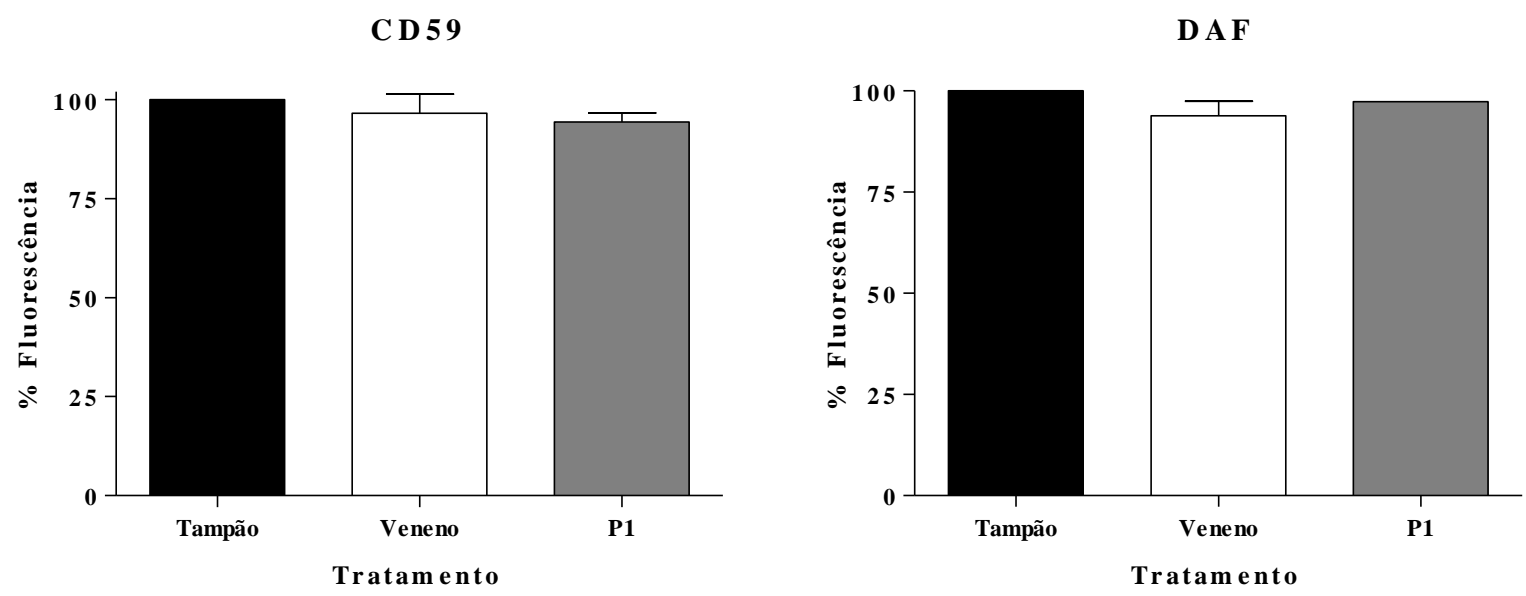

M C P

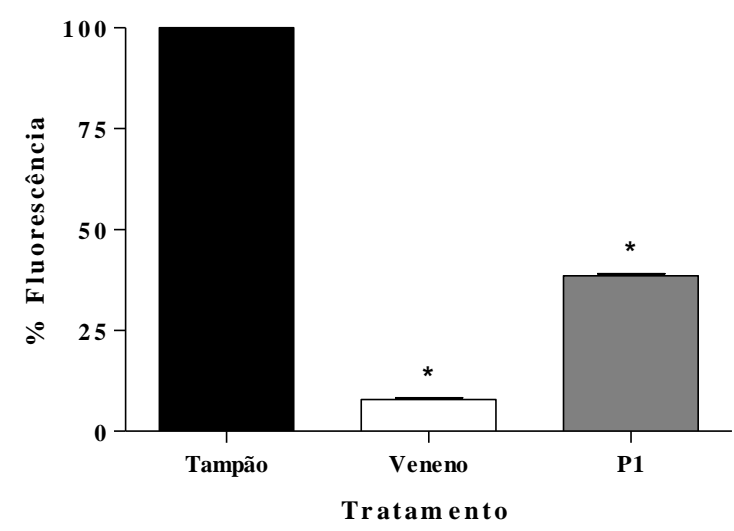




\subsection{Morte celular mediada por Complemento}

Os resultados da Figura 17 revelam que o veneno e a SMase D P1 induzem redução na expressão de MCP na superfície das células HK-2. A fim de verificar se tal remoção era capaz de permitir a ativação do Complemento, com conseqüente morte celular, $10^{6}$ células HK-2 foram tratadas com veneno ou $\mathrm{P} 1(10 \mu \mathrm{g})$, por $2 \mathrm{~h}$ e a $37^{\circ} \mathrm{C}$ e, posteriormente, incubadas com tampão, soro humano normal ou soro humano inativado por aquecimento. As células foram analisadas por citometria de fluxo, após o tratamento com iodeto de propídeo. A Figura 18 mostra um aumento significativo da ligação de iodeto de propídeo às células tratadas com veneno/toxina na presença do soro humano normal, em relação às células apenas tratadas com veneno/ toxina, na ausência de soro ou na presença do soro inativado. 
Figura 18 - Morte celular por Complemento. Células HK-2 $\left(10^{6}\right.$ células $)$ foram incubadas com $10 \mu \mathrm{g}$ do veneno ou da proteína P1 e, posteriormente, incubadas com tampão, SHN ou SHi. A morte celular foi avaliada por citometria de fluxo usando iodeto de propídeo. Resultados foram expressos como as médias das porcentagens de morte celular em experimentos realizados em duplicata $(* p<0,05)$.

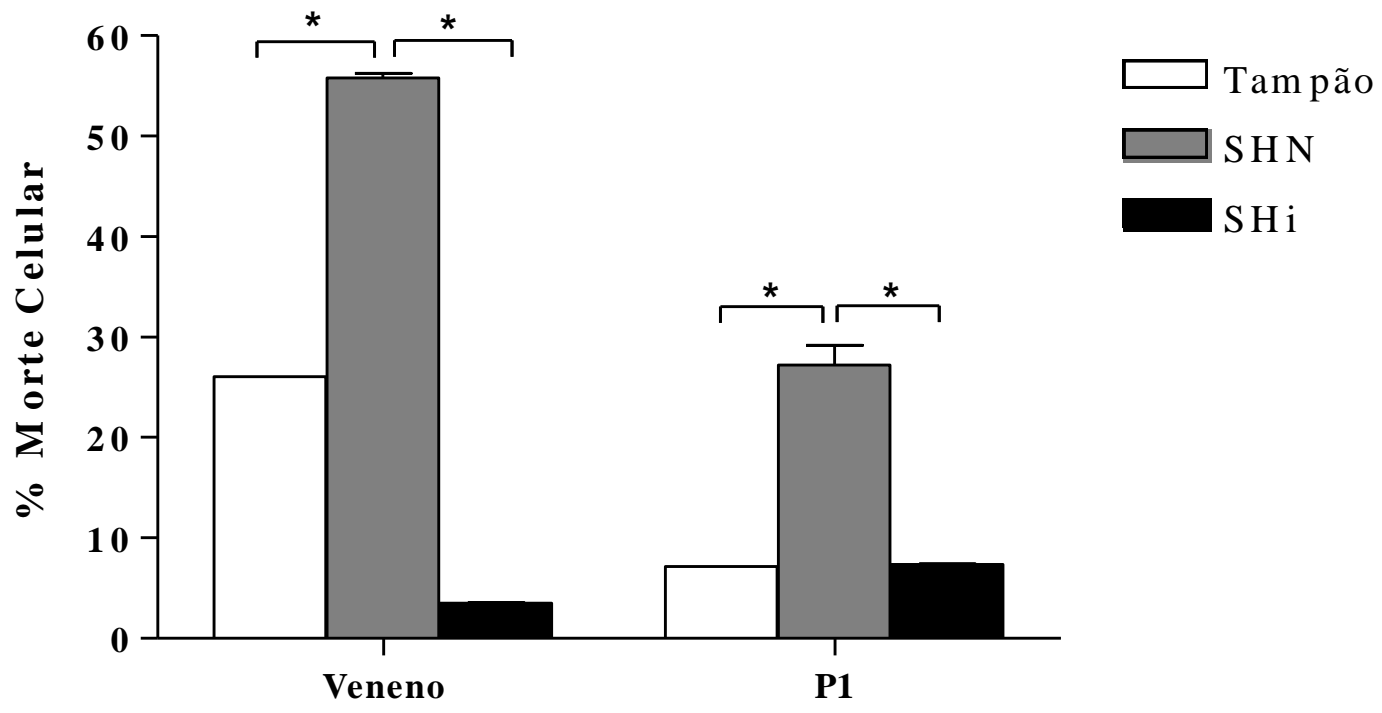




\subsection{Deposição de componentes do Complemento e outras moléculas do soro na superfície das células HK-2}

Para verificar se a morte das células HK-2 era, de fato, dependente da ativação do Complemento, células renais, pré-tratadas com veneno ou P1 (10 células/ $10 \mu \mathrm{g})$, foram incubadas com soro humano deficiente em $\mathrm{C} 8$ por 1 hora a $37{ }^{\circ} \mathrm{C}$. A deposição de componentes do Complemento foi determinada pelo ensaio de citometria de fluxo. A Figura 19 mostra um aumento significativo na deposição dos componentes C3, C4, e properdina, bem como de CRP e do fator $\mathrm{H}$, nas células tratadas com o veneno e com P1. Nas condições utilizadas, não foi possível detectar a ligação de C1q, C4bp, fB, MBL e de SAP nas células HK-2 (dados não mostrados). 
Figura 19 - Análise da deposição de componentes do Complemento na superfície das células renais. Células HK-2 (10 células) foram tratadas com $10 \mu \mathrm{g}$ do veneno (linha azul) ou da SMase P1 (linha verde) ou com tampão (linha preta) e, posteriormente, incubadas com $\mathrm{SH}$ def $\mathrm{C} 8$ por $1 \mathrm{~h}$ a $37^{\circ} \mathrm{C}$. A deposição de proteínas na superfície celular foi analisada por citometria de fluxo. Os resultados são representativos em experimentos realizados em duplicatas. Linha tracejada representa células apenas tratadas ou não e marcadas com anticorpo secundário.

\section{Veneno}
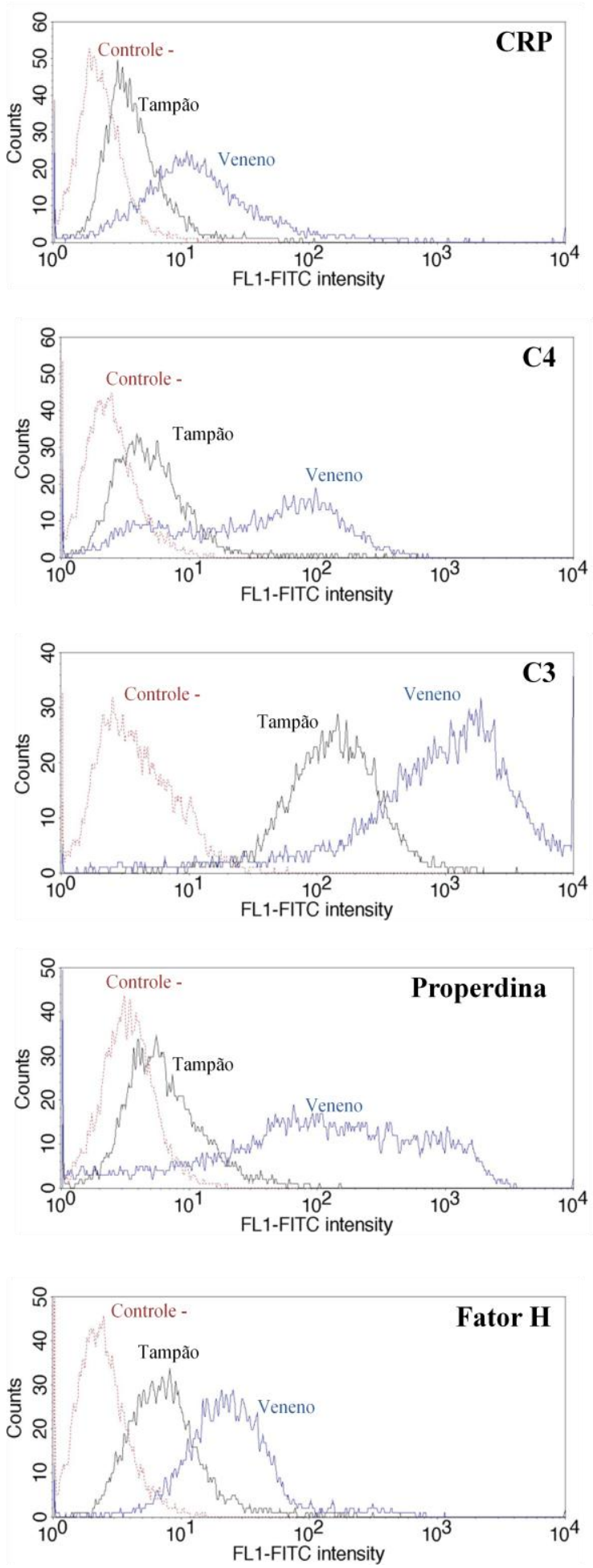

SMase D P1
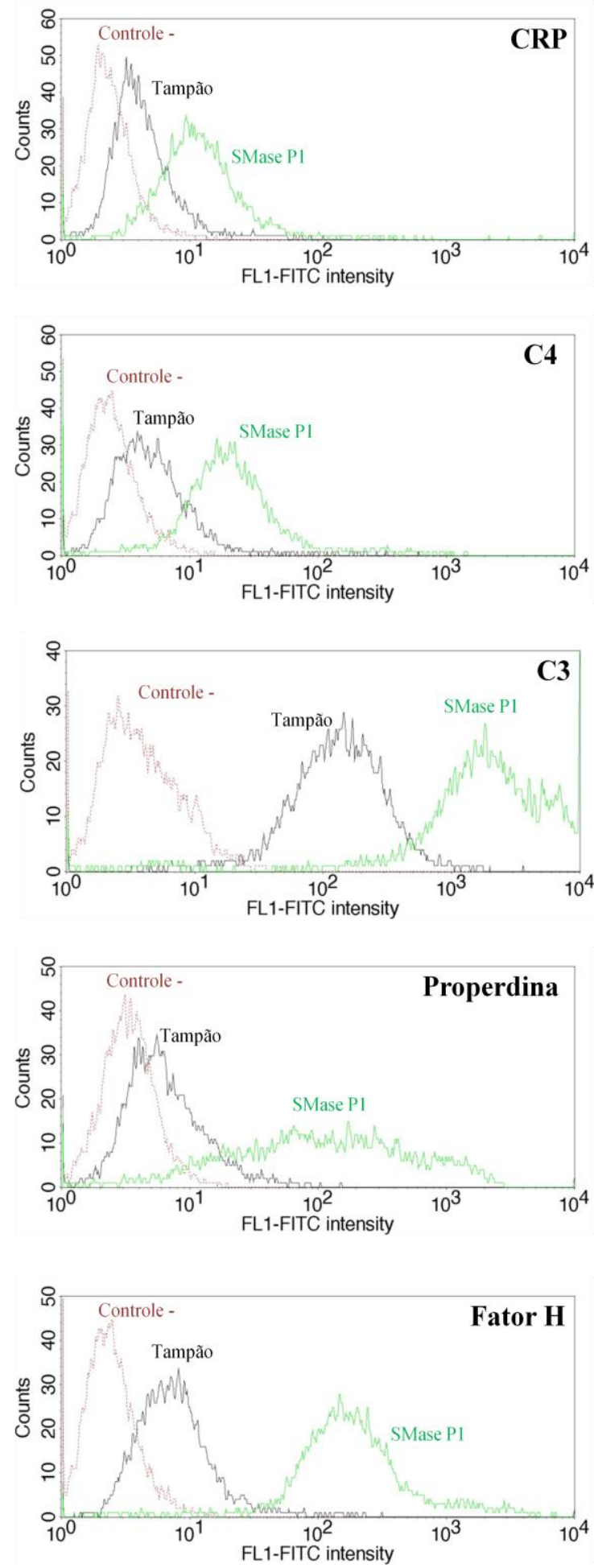


\subsection{Ligação das Esfingomielinases $D$ à superfície das células renais}

Células HK-2 $\left(10^{6}\right)$ foram incubadas por 2 horas com tampão, veneno ou SMase D P1 (10 $\mu \mathrm{g} / 10^{6}$ células) de $L$. intermedia a $37^{\circ} \mathrm{C}$. A seguir, as células foram tratadas com anticorpos anti-SMases D de Loxosceles e analisadas por citometria de fluxo. A Figura 20 mostra que a toxina P1, assim como as SMases D presentes no veneno de L. intermedia, foram capazes de se ligar à superfície das células renais. 
Figura 20 - Ligação das SMases D às células renais. Células HK-2 (10 6 células) foram incubadas com $10 \mu \mathrm{g}$ do veneno [A] ou da SMase P1 [B] ou com tampão e a ligação das esfingomielinases, à superfície celular, foi analisada por citometria de fluxo. Histograma é representativo de experimentos realizados em duplicatas.

A

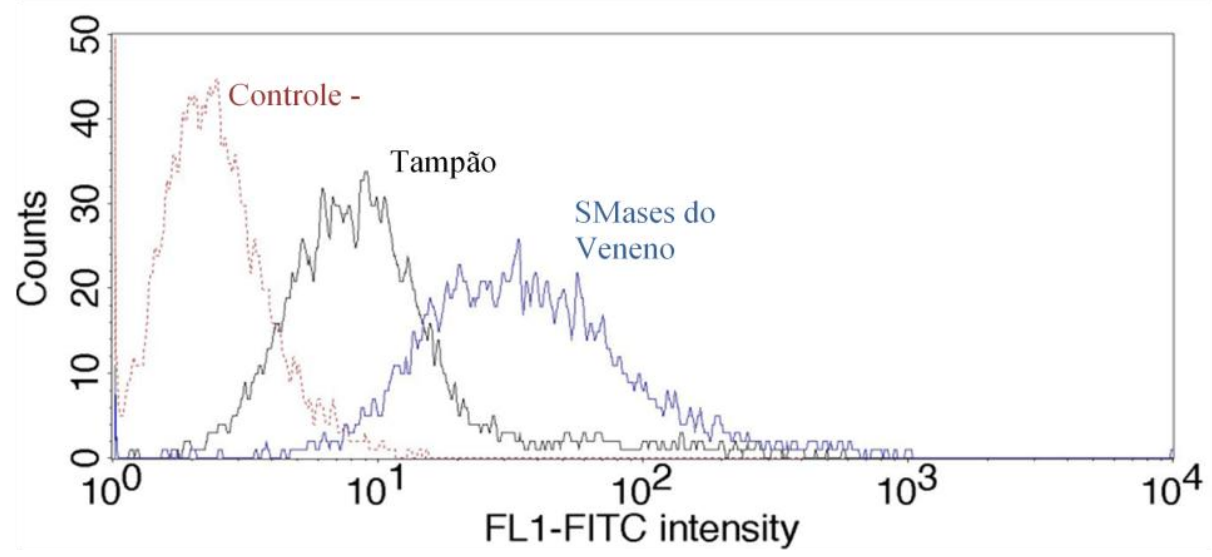

B

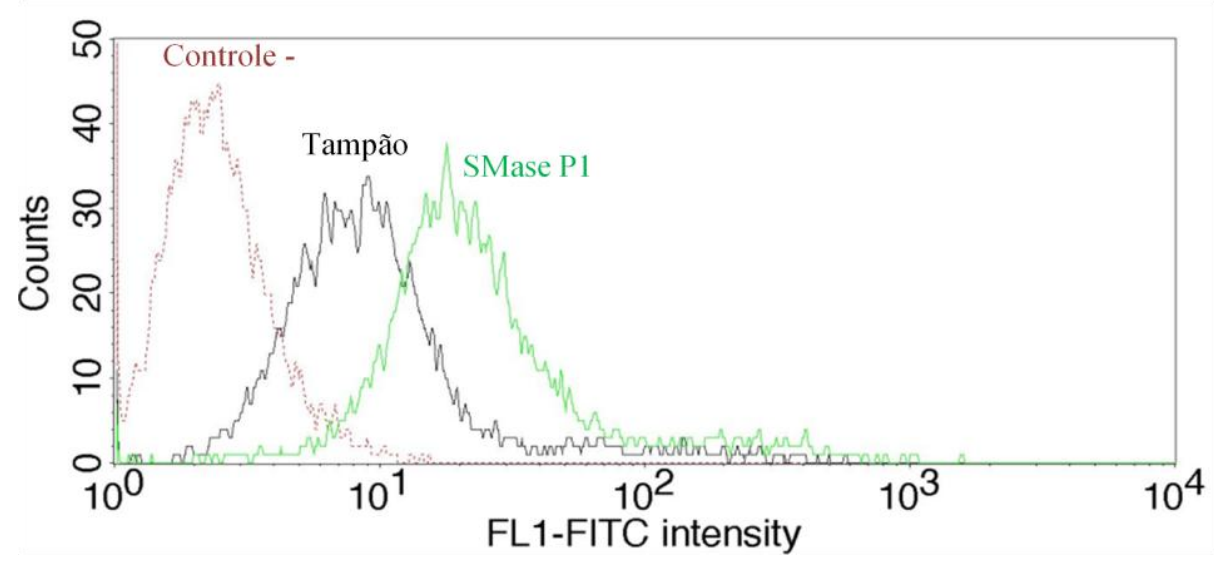




\subsection{Efeito da tetraciclina e da galardina sobre a expressão das moléculas de membrana}

Como demonstrado na Figura 16, o veneno e a SMase P1 de L. intermedia foram capazes de induzir redução na expressão dos marcadores de superfície EPCR e EGFR. Para verificar se os inibidores de MMPs, a tetraciclina, ou das adamlisinas, a galardina, poderiam controlar tal remoção, células HK-2 foram incubadas com o veneno ou SMase P1 tratadas ou não com os inibidores, e analisadas por citometria de fluxo. As Figuras 21 e 22 mostram que a galardina, mas não a tetraciclina, foi capaz de inibir a clivagem de EGFR e EPCR, indicando a participação de adamlisinas neste processo. 
Figura 21 - Efeito da tetraciclina e da galardina na expressão de EGFR das células renais. Células HK-2 foram incubadas com $10 \mu \mathrm{g} / 10^{6}$ células do veneno [A] ou da SMase D P1 [B] de L. intermedia e tratadas com tetraciclina ou galardina, e analisadas por citometria de fluxo. Resultados foram expressos como a mediana das fluorescências determinada em experimentos realizados em duplicata. ${ }^{*} p<0,05$ em relação ao controle negativo (células tratadas com tampão); ${ }^{*} p<0,05$ em relação aos controles positivos (células tratadas com veneno ou SMase D P1).

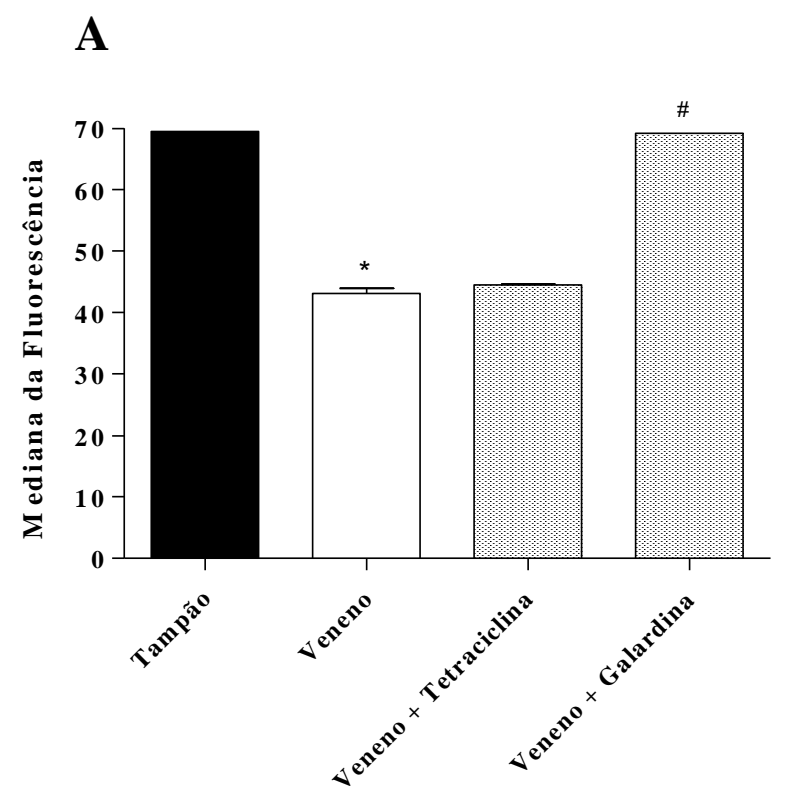

B

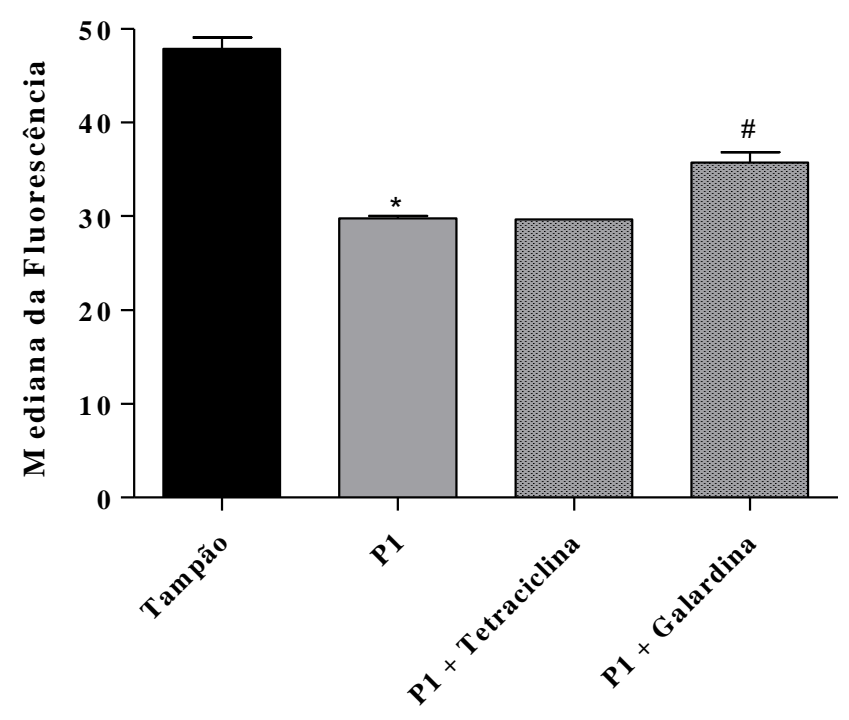


Figura 22 - Efeito da tetraciclina e da galardina na expressão de EPCR das células renais. Células HK-2 foram incubadas com $10 \mu \mathrm{g} / 10^{6}$ células do veneno [A] ou da SMase D P1 [B] de L. intermedia e tratadas com tetraciclina ou galardina, e analisadas por citometria de fluxo. Resultados foram expressos como a mediana das fluorescências determinada em experimentos realizados em duplicata. ${ }^{*} p<0,05$ em relação ao controle negativo (células tratadas com tampão); ${ }^{*} p<0,05$ em relação aos controles positivos (células tratadas com veneno ou P1).
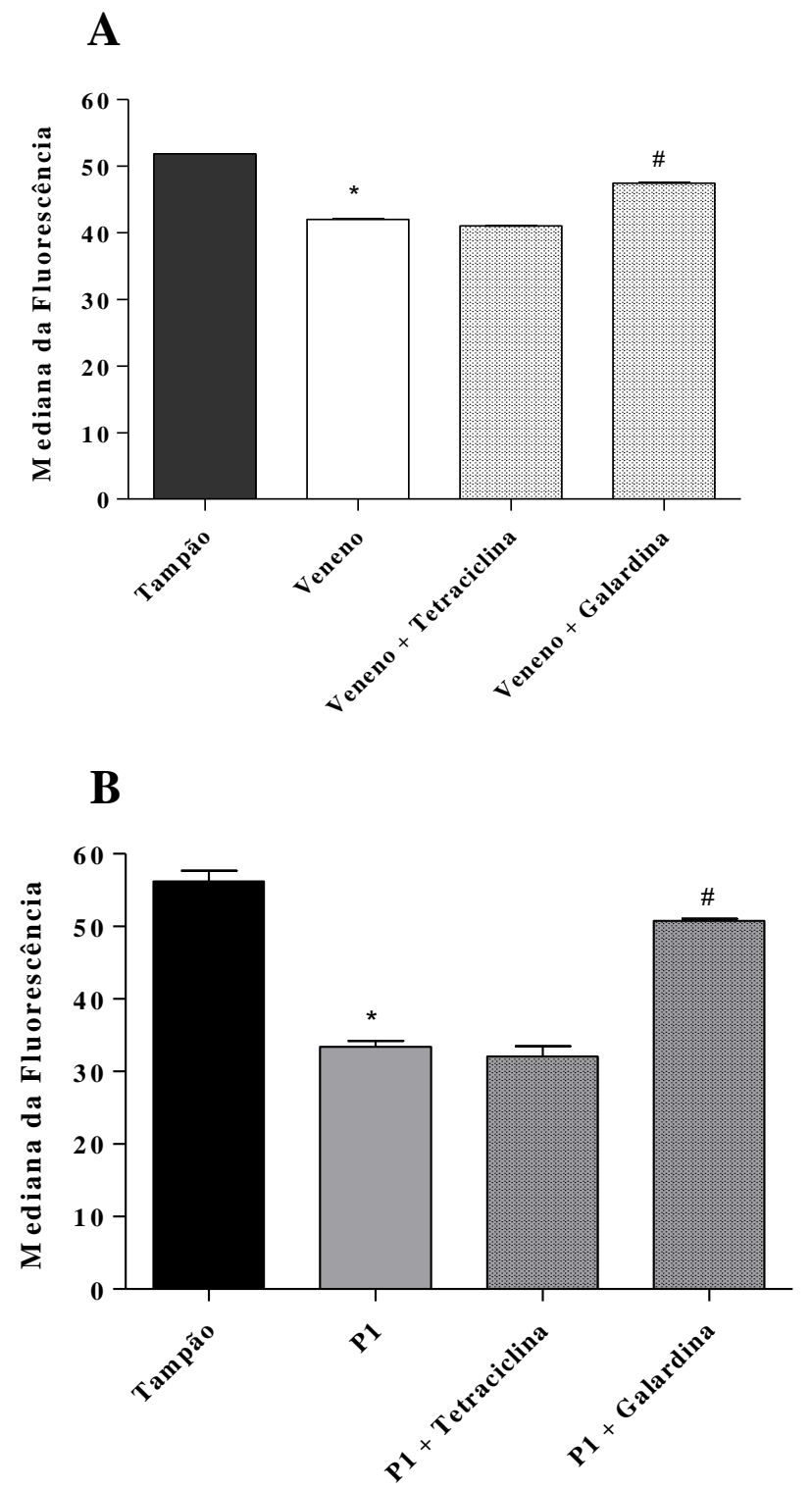


\subsection{Efeito da tetraciclina e da galardina sobre a expressão do regulador de Complemento MCP e na morte celular por Complemento}

van den Berg et al (2002), em ensaios com células endoteliais da linhagem ECV 304 incubadas com veneno de L. intermedia ou SMase D e tratadas com a galardina, mostraram que este inibidor era capaz de controlar a clivagem de MCP nestas células. Para avaliar se a galardina era também capaz de atuar desta forma nas células HK-2, estas foram incubadas com veneno de L. intermedia ou com a SMase P1, tratadas com tetraciclina ou galardina, e analisadas por citometria de fluxo. As Figuras 23 e 24 mostram que a galardina, mas não a tetraciclina, foi capaz de inibir a clivagem de MCP.

Células HK-2 incubadas com veneno ou com a SMase D P1, e tratadas com tetraciclina ou galardina foram também analisadas por Western Blot, utlizando anticorpo antiMCP. A Figura 25 mostra a presença de três bandas majoritárias nos extratos de células renais, correspondentes às isoformas de $\mathrm{MCP}$, e fragmentos deste regulador nos sobrenadantes das células tratadas com veneno ou SMase D P1 na presença ou ausência de tetraciclina, mas não de galardina.

Para verificar se o tratamento com inibidores, poderia além de prevenir a remoção de MCP, prevenir a morte celular por ativação do Complemento, células HK-2 tratadas com veneno ou SMase D P1, na presença ou não de inibidores foram incubadas com SHN, marcadas com iodeto de propídeo e analisadas por citometria de fluxo. A Figura 26 mostra que a galardina foi capaz de reduzir significativamente a morte, mediada por Complemento, das células renais tratadas com veneno/toxina. 
Figura 23 - Efeito dos inibidores de proteases na clivagem de MCP das células renais HK-2 induzida pelo veneno de $\boldsymbol{L}$. intermedia. Células HK-2 foram incubadas com veneno de L. intermedia $\left(10 \mu \mathrm{g} / 10^{6}\right.$ células), tratadas ou não com tetraciclina ou galardina, e a expressão de MCP analisada por citometria de fluxo. Resultados são representativos de dois experimentos realizados em duplicata.
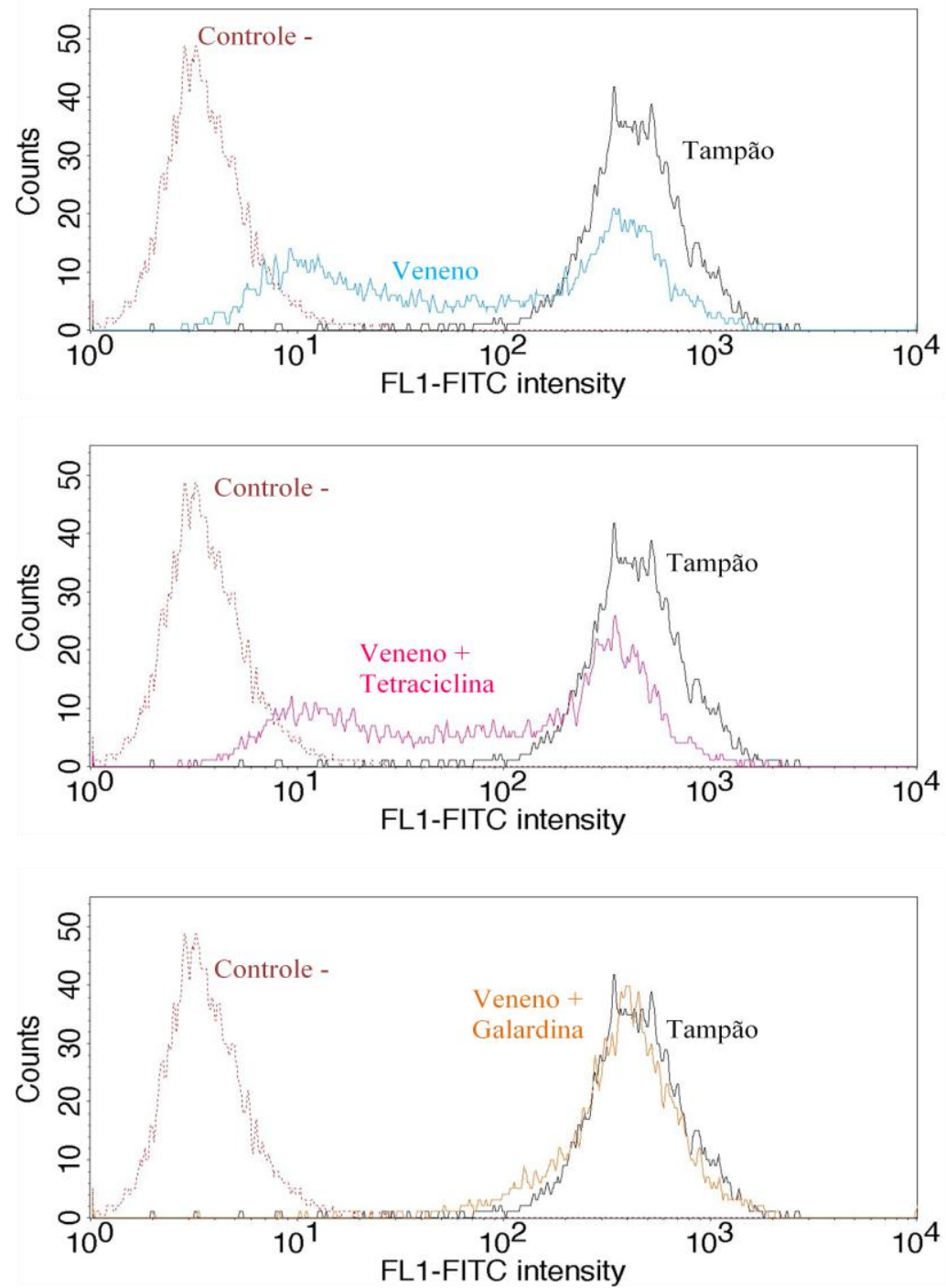
Figura 24 - Efeito dos inibidores de proteases na clivagem de MCP das células renais HK-2 induzida pela SMase D P1. Células HK-2 foram incubadas com SMase D P1 de L. intermedia (10 $\mu \mathrm{g} / 10^{6}$ células), tratadas ou não com tetraciclina ou galardina, e a expressão de MCP analisada por citometria de fluxo. Resultados são representativos de dois experimentos realizados em duplicata.
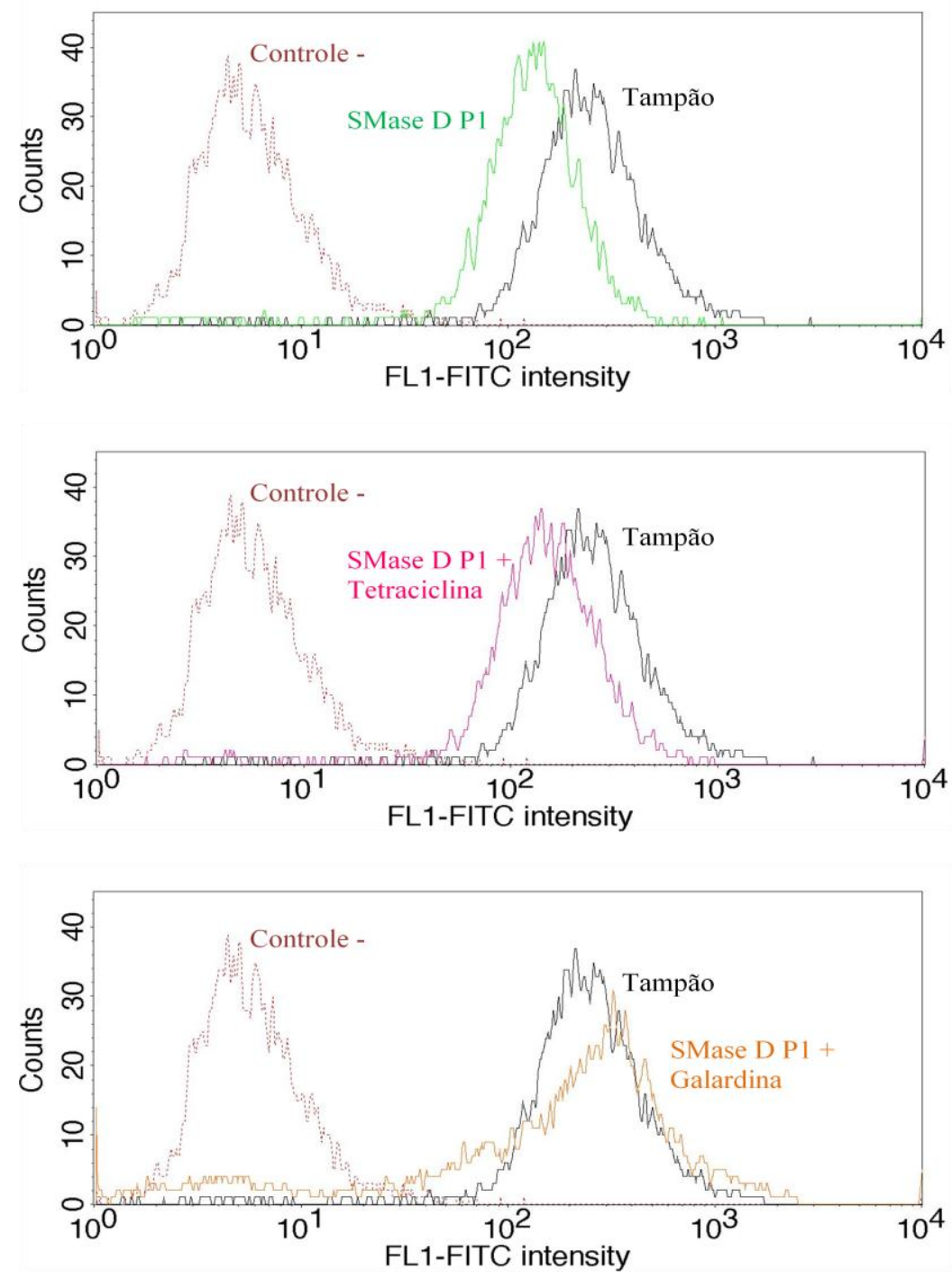
Figura 25 - Clivagem de MCP nas células renais induzidas pelo veneno e pela SMase D P1 de $L$. intermedia. Extratos (E) e sobrenadantes (S) obtidos de células HK-2 incubadas ou não com veneno [A] ou SMase D P1 [B] na presença de tampão, tetraciclina ou galardina foram analisadas por Western Blot, utilizando anticorpo monoclonal anti-MCP.

\section{A: veneno}

$\mathrm{PM}[\mathrm{kDa}]$

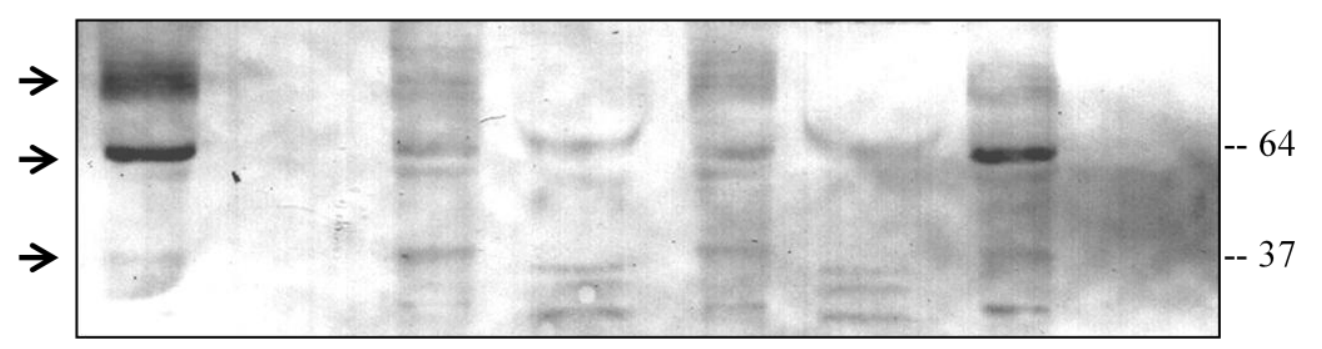

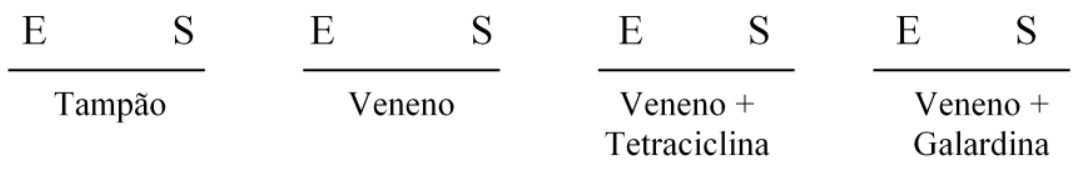

\section{B: SMase D P1}

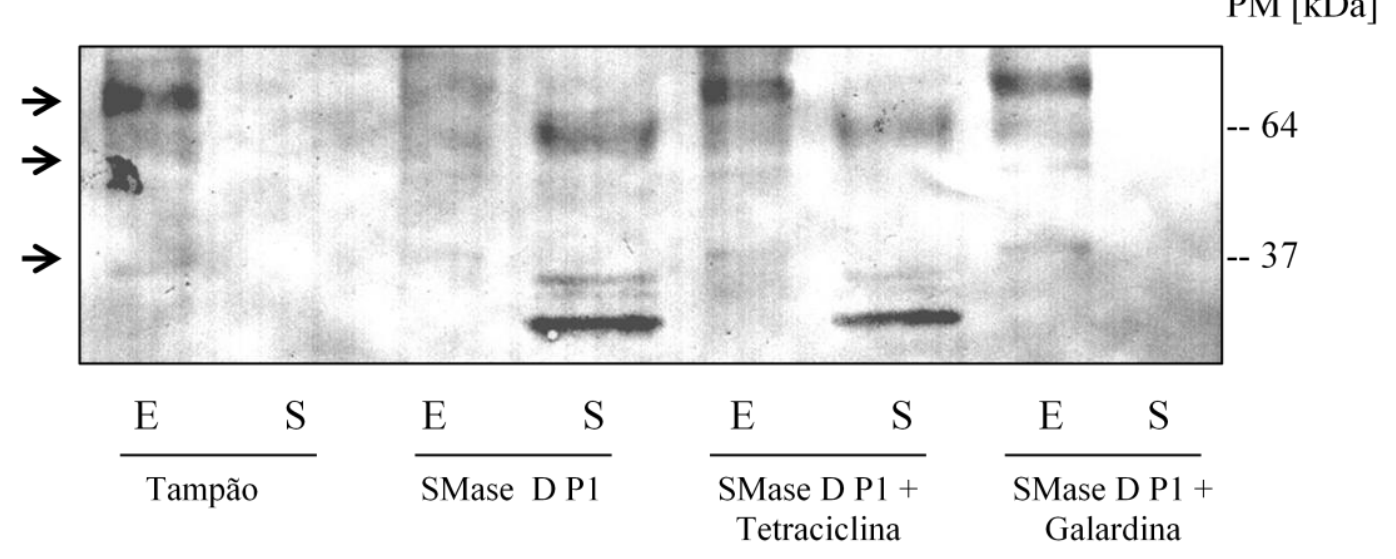


Figura 26 - Inibição da morte celular mediada por Complemento por galardina. Células HK-2 foram incubadas com tampão, veneno ou SMase P1 e tratadas com galardina. Células foram lavadas e então incubadas com SHN (1:3) como fonte de complemento. Como controle, as células foram tratadas apenas com tampão ou galardina. A viabilidade celular foi determinada por citometria de fluxo com o uso de iodeto de propídeo. Os resultados foram expressos como a média das porcentagens da morte celular e são representativos de dois experimentos realizados em duplicata.

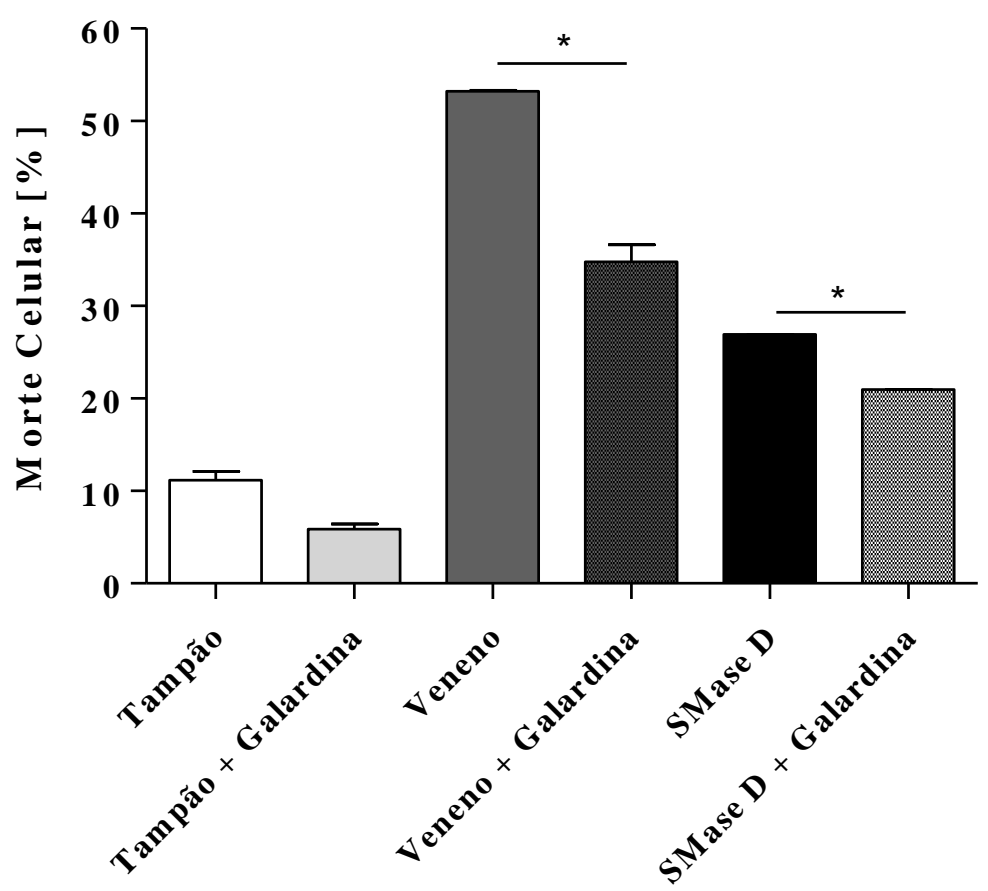




\subsection{Efeito dos inibidores de ADAM 10 e ADAM 17 sobre a clivagem de MCP e sobre a morte celular por Complemento}

Como demonstrado nas Figuras 23, 24, 25 e 26 a galardina, um inibidor de metaloproteases da família das adamlisinas, foi capaz de inibir a clivagem do regulador do Complemento MCP, presente na superfície das células HK-2, quando estas foram tratadas com veneno ou SMase D P1. Além disso, tal tratamento também resultou em redução significativa da morte celular mediada por complemento. Para analisar a participação de representantes da família das adamlisinas, como ADAM 10 e ADAM 17, no processo de remoção de MCP e morte celular, células HK-2 foram incubadas com veneno na presença dos inibidores específicos. Após a incubação, as amostras foram avaliadas quanto a expressão de MCP por citometria de fluxo. Adicionalmente amostras, assim tratadas, foram incubadas com SHN e avaliadas quanto à morte celular mediada por complemento. A Figura 27 mostra que os inibidores foram capazes de prevenir a clivagem de MCP e de reduzir significativamente a morte celular, embora com menor eficiência do que a galardina. 
Figura 27 - Efeito dos inibidores de ADAM 10 e ADAM 17 sobre a morte celular. Células HK-2 foram incubadas com tampão ou veneno e tratadas com os inibidores de ADAM 10, ADAM 17 ou galardina. Para analisar a remoção de MCP [A], células foram tratadas com anticorpos anti-MCP, incubadas com anticorpo secundário marcado com FITC e analisadas por citometria de fluxo. Os resultados foram expressos como a mediana das fluorescências determinada em experimentos realizados em duplicata. Para analisar a morte celular [B], as células foram incubadas com SHN (1:3) como fonte de complemento e a viabilidade celular analisada por citometria de fluxo usando iodeto de propídeo. Os resultados foram expressos como a média das porcentagens de morte celular. $\mathrm{p} \leq 0.05$. *tampão $\mathrm{x}$ veneno; ${ }^{\circledR}$ veneno x inibidores; ${ }^{\#}$ inibidores x tampão.

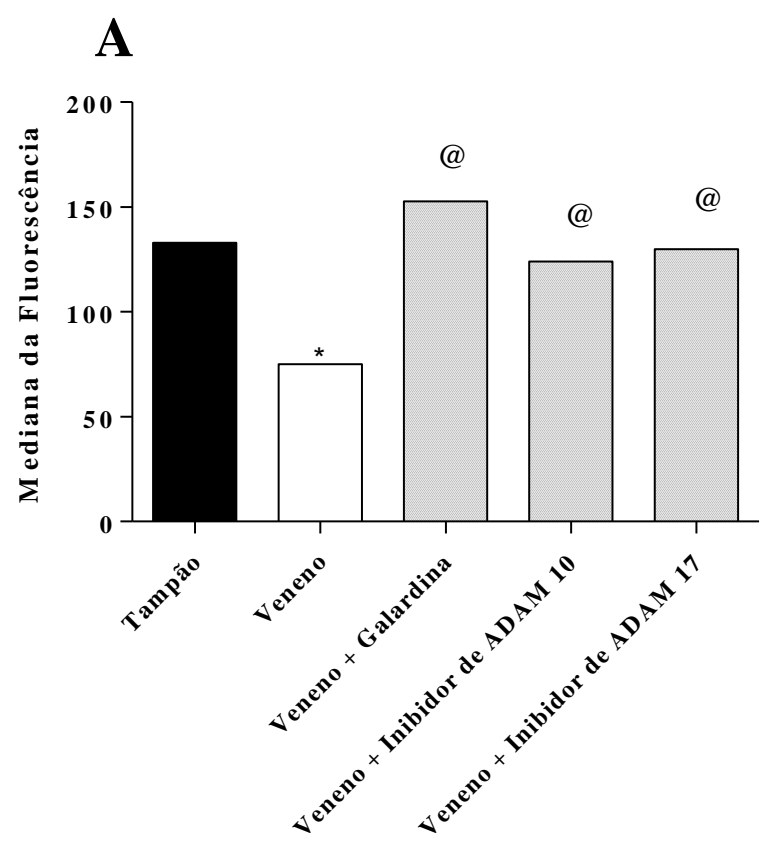

\section{B}

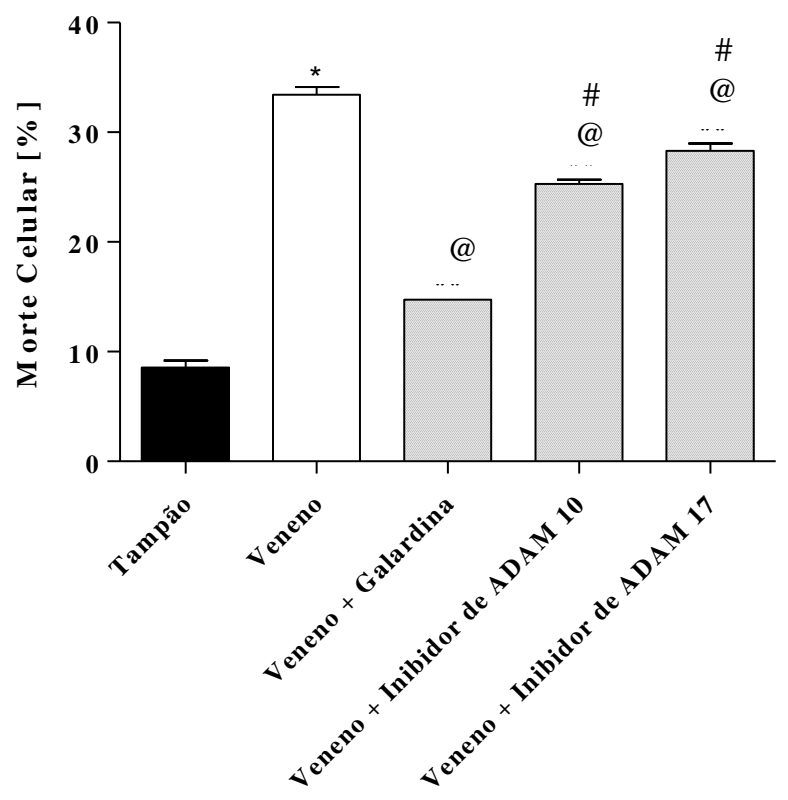




\subsection{Efeito dos inibidores de ADAM 10 e ADAM 17 sobre a clivagem de $\beta 2$ - microglobulina, EPCR e EGFR}

Como demonstrado nas Figuras 21 e 22, a galardina, mas não a tetraciclina, foi capaz de inibir a clivagem de moléculas de membrana das células HK-2, como EPCR e EGFR, quando incubadas com veneno ou SMase P1. Tal resultado indica uma possível participação de metaloproteases pertencentes à família das adamlisinas neste processo. Para avaliar essa hipótese, células renais foram incubadas com veneno e com os inibidores de ADAM 10 ou ADAM 17 e analisadas por citometria de fluxo quanto à expressão de EPCR, EGFR e também de $\beta 2 \mathrm{M}$. A Figura 28 mostra que, de fato, tais inibidores foram capazes de conter a remoção dessas moléculas de superfície em células tratadas com veneno de L. intermedia. 
Figura 28 - Efeito dos inibidores de ADAM 10 e ADAM 17 na expressão de moléculas de membrana das células renais. Células HK-2 foram incubadas com $10 \mu \mathrm{g} / 10^{6}$ células do veneno de $L$. intermedia e tratadas com galardina ou inbidores de ADAM 10 e ADAM 17, e analisadas por citometria de fluxo. Resultados foram expressos como a mediana das fluorescências determinada em experimentos realizados em duplicata. ${ }^{*} p<0,05$ para tampão x veneno; ${ }^{*} p<0,05$ para veneno $\mathrm{x}$ inibidores.

EPCR

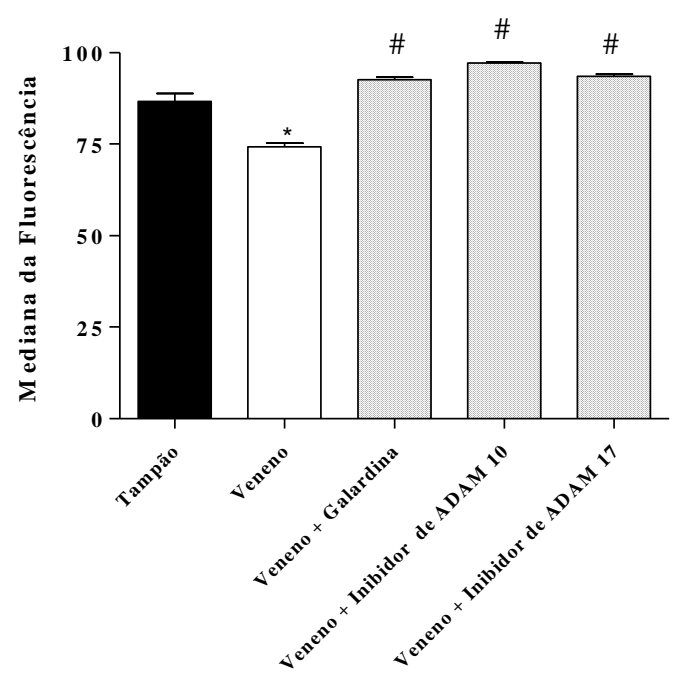

EGFR

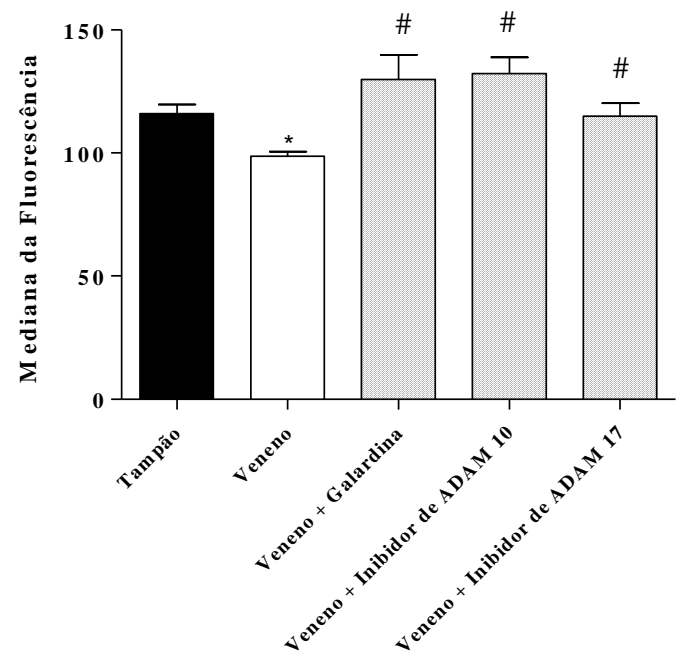

$\beta_{2}$ microglobulina

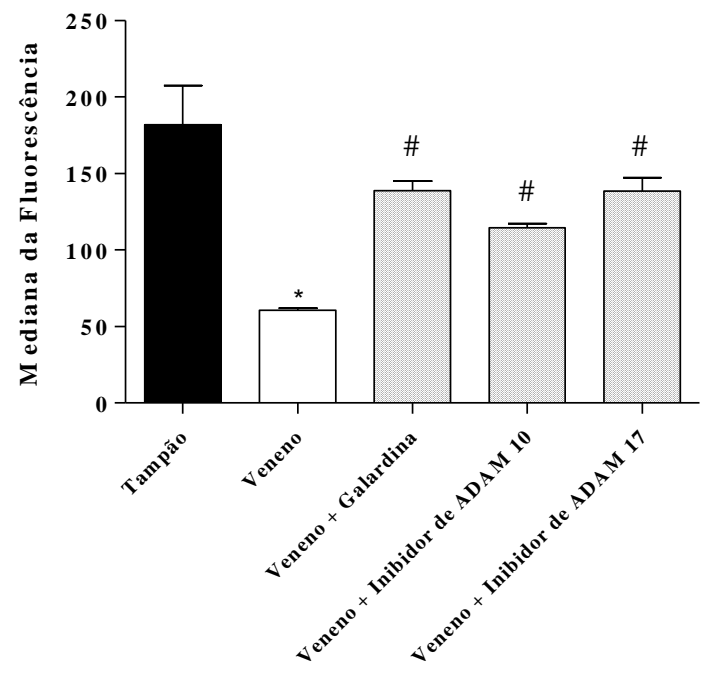




\section{DISCUSSÃO}

Envenenamentos por aranhas do gênero Loxosceles, considerados de grande importância médica no Brasil, são bem conhecidos por causarem dermonecrose, hemólise e, em casos mais graves, falência renal e morte em humanos. O veneno é composto por vários componentes protéicos, entre eles, a esfingomielinase D, sendo esta a principal enzima responsável pela maioria dos efeitos clínicos decorrentes do loxoscelismo, incluindo dermonecrose e hemólise dependente da ativação do Sistema Complemento, como demonstrado nos estudos realizados por Tambourgi et al. (2010).

Embora alguns trabalhos do nosso grupo tenham demonstrado a participação do Sistema Complemento e da ativação de metaloproteases no loxoscelismo, pouco se sabe a respeito dos mecanismos responsáveis pelos danos renais observados no envenenamento por aranhas Loxosceles. Assim, o objetivo deste estudo foi analisar a participação destes elementos no dano de células renais promovido pelo veneno de L. intermedia e por uma de suas esfingomielinases D, a P1.

A partir do clone contendo o cDNA que codifica para a esfingomielinase P1 de $L$. intermedia, foi realizada a expressão e purificação da proteína recombinante, por cromatografia de afinidade em colunas contendo níquel, uma vez que a toxina expressa apresenta uma cauda de histidina na sua região $\mathrm{N}$-terminal. A purificação ocorreu com sucesso, como revelado em ensaios de eletroforese, que revelaram a presença de uma única banda protéica, com peso molecular em torno de $37 \mathrm{kDa}$. A esfingomielinase se mostrou ativa, capaz de clivar o substrato esfingomielina com maior eficiência, do que o veneno bruto de L. intermedia. Ensaios de hemólise revelaram também que a proteína e o veneno estavam ativos e capazes de induzir a lise dos eritrócitos, dependente da ativação do complemento.

Por ser um órgão altamente especializado, o rim está sujeito à injúria por vários fatores externos. Lesões no túbulo renal, decorrentes de isquemia e da exposição à nefrotoxinas, são as causas mais comuns da disfunção aguda dos rins (BENNETT et al., 1991, LESHER e SONG, 2010). Assim, uma vez verificada a atividade do veneno e da SMase P1, estes foram testados quanto à toxicidade sobre células renais humanas da linhagem HK-2, derivadas do túbulo proximal. Nestes ensaios foram utilizadas quantidades crescentes de veneno ou da SMase P1, sendo a viabilidade determinada pelo método de MTT. Tal método permite a detecção de células viáveis, pela capacidade de formar cristais de formazam, quando do contato do MTT com a desidrogenase mitocondrial. Semelhante ao demonstrado por Luciano 
et al. (2004), utilizando células renais de camundongos, e Ribeiro et al. (2007), utilizando células renais de macacos, o veneno de Loxosceles se mostrou tóxico para as células, causando cerca de $30-40 \%$ de morte celular. A proteína recombinante P1 foi mais tóxica, causando $100 \%$ de morte celular, com apenas $5 \mu$ g da proteína e após 48 horas. Às 72 horas, todas as células estavam mortas em todas as concentrações da proteína ensaiadas, indicando que a ação tóxica das esfingomielinases possa contribuir para o desenvolvimento dos danos renais. As células HK-2 parecem ser mais sensíveis à ação das SMases do que os queratinócitos humanos, uma vez que Paixão-Cavalcante et al. (2006) demonstraram que 10 $\mu \mathrm{g}$ da SMase D recombinante $\mathrm{P} 2$ de L. intermedia causava cerca de $60 \%$ de morte celular às $72 \mathrm{~h}$.

As metaloproteases de matriz (MMPs) pertencem a uma família de endopeptidases, zinco-dependentes, presentes na forma secretada ou ligada à membrana celular, e que podem ser classificadas em vários subgrupos, como colagenases, elastases, gelatinases, matrilisinas e metaloproteases de membrana. São capazes de hidrolisar uma variedade de proteínas, entre elas, componentes de matriz extracelular, como colágeno e fibronectina, e moléculas de superfície celular (LEEHEY et al., 1995; YEE, 1998). As MMPs estão envolvidas na estrutura e homeostase tecidual e em algumas patologias, como diabetes melitus, metástase de tumores e artrite reumatóide (STAMENKOVIC, 2003). Estas enzimas são reguladas por meio da modulação da expressão gênica ou por inibidores, sendo que a maioria delas não é transcrita constitutivamente, porém sua expressão pode ser induzida por fatores externos como citocinas e fatores de crescimento (TALLANT et al., 2009).

Mudanças na expressão de MMPs podem levar a danos glomerulares e declínio da função renal, como demonstrado em estudos realizados por BASILE et al. (2004), indicando que a expressão de MMP-2 e MMP-9 pode levar à isquemia renal aguda. Koide et al. (1996) mostraram que o aumento das MMPs, na doença inflamatória renal, leva à degradação da matriz extracelular. Também podem estar associadas a outras nefropatias, como a proteinúria, perda da permeseletividade, aumento do epitélio glomerular e fibrose renal (McMILLAN et al, 1996, NAÍNI et al., 2007).

Alguns trabalhos indicam o envolvimento das MMPs no loxoscelismo cutâneo. Tambourgi et al. (2005) e Paixão-Cavalcante et al. (2006 e 2007) mostraram, em ensaios in vivo com coelhos e in vitro com células $\mathrm{HaCaT}$, que as esfingomielinases e o veneno de $L$. intermedia, induziam aumento na secreção das MMPs (MMP-2 e MMP-9) e que tal fato também tinha uma relação direta com a perda de viabilidade celular por apoptose. 
Para analisar o envolvimento da expressão/secreção de MMPs nos danos renais do loxoscelismo, sobrenadantes de células renais tratadas com diferentes quantidades de veneno ou SMase P1 de L. intermedia foram analisados por zimografia. Os resultados obtidos mostram que tanto o veneno, como a SMase P1, foram capazes de induzir um aumento na expressão e/ou secreção das metaloproteases endógenas MMP-2 e MMP-9.

Tetraciclinas têm sido utilizadas há décadas em tratamentos de processos infecciosos e, atualmente, aplicadas na terapia de doenças nas quais há a participação de metaloproteases de matriz, como a osteoatrite degenerativa, periodontites e câncer (MURPHY et al., 1999). Estas inibem, dentre outras, as gelatinases MMP-2 e MMP-9, por meio de vários mecanismos, entre eles: bloqueio da atividade das MMPs maduras, pela quelação dos átomos de zinco do sítio ativo das enzimas; inibição das pro-MMPs; redução da expressão das MMPs e proteção das MMPs contra a degradação proteolítica e oxidativa de outras proteases (GOLUB et al., 1984).

Paixão-Cavalcante et al. (2006), em ensaios in vitro utilizando queratinócitos humanos, mostrou que a tetraciclina inibe a ação tóxica do veneno e das SMases D de L. intermedia na viabilidade celular, como também previne a expressão/ secreção de MMP-2 e MMP-9. Além disso, utilizando coelhos, como modelo experimental de loxoscelismo cutâneo, PaixãoCavalcante et al. (2007) mostraram que o uso tópico da tetraciclina era capaz de reduzir significantemente a lesão dermonecrótica induzida tanto pelo veneno, quanto pela SMase D de L. intermedia. Ainda neste estudo, mostraram que a redução da lesão estava relacionada com a diminuição da expressão/secreção das MMPs, no sítio de inoculação das toxinas.

No presente estudo foi demonstrado que o veneno e a SMase D de L. intermedia são capazes de promover a expressão/secreção de MMP-2 e MMP-9 pelas células renais HK-2 e causar diminuição da viabilidade celular. O uso da tetraciclina, no entanto, se mostrou tóxico para as células renais, nas concentrações acima de $30 \mu \mathrm{g}$. Assim, as células renais foram tratadas com $5 \mu \mathrm{g}$ do veneno ou da SMase D P1 e $20 \mu \mathrm{g}$ da tetraciclina, concentração na qual o inibidor causou cerca de $10 \%$ de redução na viabilidade celular. Os resultados obtidos indicam que, assim como na lesão dermonecrótica, a tetraciclina foi capaz de inibir, significativamente, a morte das células HK-2 e reduzir a expressão/secreção das MMPs. A análise da expressão gênica foi realizada a partir da extração do RNA das células incubadas por $48 \mathrm{~h}$ com o veneno ou a toxina P1 tratadas ou não com tetraciclina. Corroborando os dados obtidos nos ensaios de zimografia, os ensaios de PCR revelaram um aumento na expressão tanto de MMP-2 quanto de MMP-9 nas células, tratadas com veneno/toxina, e que tal aumento poderia ser inibido pelo uso da tetraciclina. 
O Fator de Crescimento Epidermal (EGFR) é uma glicoproteína transmembrânica que, junto ao seu ligante, leva à autofosforilação do receptor de tirosina quinase e, subseqüiente, ativação das vias de transdução de sinais, envolvida na regulação da proliferação celular, diferenciação e sobrevivência (HERBST, 2004). Estudos de Cox et al. (2000) sugerem que a sinalização via EGFR pode induzir o aumento da expressão de MMP-9 em células tumorais. Os resultados obtidos neste trabalho mostram que as células renais humanas, incubadas tanto com o veneno quanto com a SMase P1, sofrem diminuição da expressão de EGFR. PaixãoCavalcante et al. (2006) também demonstraram, em estudos sobre o loxoscelismo cutâneo que, em células HaCaT, ocorre redução do EGFR, a qual pode estar relacionada ao desenvolvimento da lesão dermonecrótica induzida pelo veneno, uma vez que a baixa expressão de EGFR poderia contribuir para o não reparo da lesão.

No presente estudo foi demonstrado que a expressão do receptor endotelial para proteína C (EPCR) estava também reduzida nas células HK-2, incubadas com o veneno ou a SMase P1 de L. intermedia. A redução deste fator pode também estar contribuindo para a morte celular, uma vez que ele está envolvido no controle da coagulação, inflamação e apoptose. A redução da expressão do EPCR parece ser decorrente da ação de metaloproteases da família das adamlisinas, uma vez que a galardina, mas não a tetraciclina, foi capaz de inibir a clivagem deste receptor em células renais incubadas com veneno ou SMase P1. Estes resultados também foram encontrados por van den Berg et al. (2007), em culturas primárias de células endoteliais (HUVECs) tratadas com veneno/ SMase D, nas quais foi demonstrada redução da expressão de EPCR e trombomodulina, pela ativação de metaloproteases endógenas. Xue et al.(2007) mostraram, em estudos com queratinócitos, que ao bloquear os receptores EPCR e EGFR, presentes na membrana destas células, ocorre uma diminuição na proliferação celular e aumento da morte por apoptose. De forma semelhante, nossos resultados mostram que as células renais tratadas com veneno/ SMase P1 apresentam redução na expressão de EGFR e EPCR a qual pode estar relacionada à morte celular por apoptose como demonstrado pelo aumento da ativação da caspase-3.

A apoptose é a um mecanismo importante que leva a morte celular caracterizada, inicialmente, por uma série de mudanças morfológicas, fragmentação do DNA e exposição de fosfatidilserina na superfície celular (LIU e HENGARTNER, 1999). A ativação das caspases, proteínas pertencentes à família das cisteíno proteases que clivam substratos com resíduos de aspartato, desempenha um papel central na morte celular programada (MEIER et al., 2000, GRIVICICH et al., 2007). 
Veneno e a SMase D foram também capazes de induzir redução na expressão, nas células HK-2, de outras moléculas de superfície como o MHCI e a $\beta 2$ microglobulina. Esses resultados estão de acordo com os de van den Berg et al (2002), que mostraram a clivagem de MHCI em células endoteliais ECV 304 e que este fenômeno ocorria por uma ação indireta do veneno de Loxosceles, ou seja, por meio da ativação de adamlisinas. Tais resultados também foram obtidos em queratinócitos humanos tratados com veneno de Loxosceles e SMase P2 (PAIXÃO-CAVALCANTE et al, 2006); em adição, a tetraciclina não foi capaz de inibir a redução da expressão da $\beta 2$ microglobulina, mas sim o EDTA, sugerindo a participação de metaloproteases na clivagem, mas não de MMPs.

O Sistema Complemento é composto por vários componentes protéicos presentes no plasma sanguíneo, que atuam na defesa do organismo contra infecções e possui grande relevância na homeostasia do sistema renal, pela presença de seus reguladores na superfície celular e no plasma. Muitos estudos têm demonstrado que diversas patologias renais podem estar associadas à ativação imprópria do Complemento ou à deficiência de alguns reguladores, como as encontradas nas isquemias, inflamações, hemoglobinúria e doenças autoimunes (MORGAN e HARRYS, 2003). Turnenberg et al. (2003) demonstraram que camundongos nocauteados para o gene do CD59 eram mais suscetíveis à nefrite do que os normais, sugerindo a importância deste regulador da formação do complexo de ataque à membrana (MAC) na proteção à injúria glomerular. Lin et al. (2004) também demonstraram que além da importante participação do CD59, o fator de aceleração de decaimento (DAF) também exerce função essencial contra a nefrotoxicidade. Outros estudos, utilizando ratos deficientes do componente C6, mostraram que estes eram protegidos dos efeitos lesivos do MAC, fator iniciador da síndrome nefrótica (NANGAKU et al., 1999 e 2002). A participação do Complemento foi também demonstrada nas patologias associadas aos danos na área túbulointersticial nas quais isquemias renais levam à ativação da via alternativa e são independentes de anticorpos (CAMUSSI et al., 1982).

Para analisar o possível envolvimento do Sistema Complemento nos danos renais provocados pelo loxoscelismo, células HK-2 foram incubadas com veneno ou SMase P1 e, em seguida, incubadas na presença ou ausência de soro normal humano, como fonte de complemento, ou com soro inativado. Os resultados obtidos mostraram um aumento na morte celular em células tratadas na presença do soro humano normal, mas não do inativado. Para confirmar a participação do complemento na morte celular induzida pelo veneno ou toxina, células HK-2, tratadas ou não, foram incubadas com soro humano deficiente do componente 
C8, a fim de evitar a formação do MAC (Complexo de Ataque à Membrana), e analisadas por citometria de fluxo quanto à deposição de componentes das vias de ativação do complemento. Os resultados obtidos mostraram um aumento na deposição de $\mathrm{C} 3, \mathrm{C} 4$ e properdina na membrana das células renais.

Properdina, proteína de $53 \mathrm{kDa}$, é um regulador positivo do sistema complemento que atua sobre a via alternativa, estabilizando as C3 e C5 convertases. A properdina pode se ligar à C3 convertase da via alternativa (instável no plasma) e proteger este complexo da clivagem pelo fator I na presença de cofatores. A deficiência desta proteína facilita a infecções por meningocócitos, otites e pneumonias (FIJEN et al., 1999; STOVER et al., 2008; SCHEJBEL et al., 2009). Recentemente foi demonstrado que na doença renal por proteinúria, ocorre a deposição de properdina na região tubular dos rins, ativando a via alternativa do complemento (GAARKEUKEN et al. 2008, ZAFERANI et al., 2011). Células renais tratadas com veneno/ P1, na presença do soro humano normal, apresentaram um aumento da deposição dessa proteína na membrana destas células.

Ainda, nos ensaios de citometria de fluxo, foi observado um aumento da ligação da proteína CRP e do regulador solúvel do Complemento, fator $\mathrm{H}$, à membrana das células renais. A Proteína C Reativa (CRP), assim como a SAP (Proteína Soro Amilóide), são membros da superfamília das pentraxinas e consideradas como possíveis fatores iniciadores da via clássica do Complemento (VOLANAKIS, 1982; DEBAN et al., 2009). A proteína se associa às células necróticas ou apoptóticas por meio de vários ligantes presentes na membrana celular, como fosfatidilcolina, fosfatidilserina e DNA (BLACK et al., 2004; MIHLAN et al., 2009), sendo tal ligação depende da presença de íons $\mathrm{Ca}^{2+}$. Além disso, CRP participa na resposta inflamatória e na opsonização dependente do Complemento (PEPYS e HIRSCHFIELD, 2003). Estudos recentes mostram que, em processos inflamatórios, CRP pode se associar à ficolina, ativando a via das lectinas e resultando na clivagem de $\mathrm{C} 4$ (NG et al., 2007; RUNZA et al., 2008; ZHANG, ALI, 2008). Assim, o aumento da deposição de C4 na superfície das células HK-2, após tratamento com veneno/ SMase D, pode ser decorrente da deposição de CRP e ativação do complexo ficolina/ MASP-2.

Estudos de Tambourgi et al. (2002, 2007) demonstraram que a CRP tem papel fundamental na hemólise de eritrócitos humanos, dependente da ativação da via clássica do Complemento, induzida pelas SMases D de Loxosceles. A ligação de CRP à superfície dos eritrócitos tratados, mas não nos normais, permitiu a associação de $\mathrm{C} 1 \mathrm{q}$ com, conseqüente, ativação da via clássica e lise celular. Apesar de termos observado a ligação de CRP à 
superfície das células renais, quando tratadas com veneno/ SMase D, não foi possível detectar, nas condições utilizadas, a ligação de C1q. Além disso, não foi observada deposição de MBL nas células renais, previamente tratadas com veneno/ toxina (dados não mostrados).

Além da ligação de CRP à superfície celular, dados dos ensaios de citometria de fluxo mostraram um aumento na deposição do fator $\mathrm{H}$, um dos reguladores da via alternativa, capaz de acelerar o decaimento da C3 convertase, atuando como co-fator para a degradação de C3b a iC3b mediada pelo fator I (ZIPFEL et al., 2009).

$\mathrm{O}$ fator H, glicoproteína presente em abundância no plasma, participa na regulação da via alternativa do sistema complemento tanto na fase fluída quanto na superfície celular. Estudos realizados por Buelli et al. (2009) mostraram que o fator $\mathrm{H}$ liga-se a resíduos de sulfato de heparan presente na superfície das células renais e que a diminuição destes resíduos impede a ligação do fator $\mathrm{H}$ e aumento na deposição de C3. Sjöberg et al. (2007) demonstraram que a ativação dos componentes tardios do complemento, para a formação do complexo lítico, era inibida pela ação dos reguladores fator $\mathrm{H}$ e $\mathrm{C} 4 \mathrm{bp}$, que se ligam à proteína CRP, depositada na superfície celular. Os resultados aqui apresentados mostram que as esfingomielinases D recombinantes ou presentes no veneno atuam na superfície celular das células HK-2 facilitando a ligação do fator $\mathrm{H}$, embora tal evento não tenha sido suficiente para o controle da ativação do Complemento, com conseqüente morte celular. Trabalho proposto por Thurman et al. (2006) mostraram que a ativação não regulada da via alternativa estava associada à lesão renal isquêmica, como observado em modelo murino. Observaram, ainda, redução do regulador de membrana Crry (análogo ao MCP de humanos) e presença de alta concentração de fator $\mathrm{H}$ no epitélio do túbulo proximal. No entanto, a presença de fator $\mathrm{H}$ não foi capaz de proteger a superfície destas células, tornando o rim isquêmico susceptível à ativação da via alternativa.

Eventos como aumento da deposição de componentes do complemento, clivagem de marcadores de superfície e morte celular foram positivamente relacionados à ligação das SMases D, recombinantes ou presentes no veneno, à superfície das células HK-2.

Uma vez demonstrado que o Sistema Complemento pode contribuir para a morte das células renais induzida pelas SMases D/ veneno de Loxosceles, analisamos as possíveis mudanças na expressão dos reguladores de membrana do Complemento, a fim de verificar se a ativação do Sistema era decorrente da alteração destas proteínas. Os dados obtidos, por citometria de fluxo, mostram uma redução de MCP, mas não de CD59 ou DAF na superfície das células HK-2 após tratamento com P1/ veneno. 
MCP (proteína cofator de membrana; CD46) é uma glicoproteína, de peso molecular de entre 45-70 kDa, presente em todos os tipos celulares, com exceção dos eritrócitos, e que possui atividade de cofator para ação do fator I, na clivagem de C3b e C4b em fragmentos inativos (NANGAKU, 1998; BARILLA-LaBARCA et al., 2002). Este regulador é altamente expresso nas células renais (NANGAKU, 1998), localizado ao longo da parede dos capilares glomerulares e na região mesangial, sendo que a deficiência ou mutação de MCP pode estar associada a diversas patologias como isquemia renal aguda, glomerulonefrite e síndrome hemolítica urêmica (ATKINSON et al., 2005, CAPRIOLI et al., 2006).

Resultados obtidos por van den Berg et al. (2002) mostraram a clivagem de MCP em células endoteliais ECV304 tratadas com veneno de L. intermedia. No entanto, neste modelo, a remoção de MCP não resultou em aumento da susceptibilidade à morte celular por complemento. No presente estudo, foi observado que a clivagem de MCP na superfície das células renais $\mathrm{HK}-2$, induzida pela esfingomielinase recombinante ou veneno, causou um aumento na susceptibilidade à morte celular por ativação do Sistema Complemento, mesmo na presença de outros reguladores de superfície, como DAF e CD59, e do regulador solúvel fator $\mathrm{H}$.

Resultados obtidos, até o momento, mostram que a ação tóxica do veneno/SMases D, sobre células renais $\mathrm{HK}-2$, se dá por mecanismos indiretos, associados à ativação de metaloproteases endógenas. Além do uso da tetraciclina, como inibidor das MMPs, utilizamos neste estudo a galardina, um potente inibidor de metaloproteases da família das adamlisinas. Desta forma, foi possível demonstrar que a remoção de EPCR, EGFR, $\beta 2$ microglobulina e MCP, induzida por ação do veneno/ SMase D, pode ser inibida pelo uso da galardina, mas não de tetraciclina, sugerindo a participação de ADAMs neste evento.

Proteínas pertencentes à família das adamlisinas estão localizadas na porção transmembrânica das células de mamíferos, são dependentes de íons zinco e estão envolvidas, principalmente, nos processos inflamatórios, de controle da liberação de citocinas e de migração celular (SEALS, COURTNEIDGE, 2003; EDWARDS et al., 2008); além disso, também podem influenciar a interação das células com a matriz extracelular pela clivagem e modelação das proteínas presentes na matriz (WHITE, 2003).

Estudos realizados por van den Berg et al. (2002) com células endoteliais da linhagem ECV304 mostraram que tanto o veneno quanto a SMase D P1 eram capazes de induzir a clivagem de MCP e de MHCI, pela ativação de metaloproteases pertencentes à família das adamlisinas e que esta clivagem podia ser inibida pelo uso da galardina. Tambourgi et al. 
(2000), em ensaios com eritrócitos, observaram que tanto o veneno quanto as toxinas purificadas, induziam a ativação de metaloproteases presentes na membrana capazes de agir sobre as glicoforinas de membrana, que uma vez clivadas tornaram os eritrócitos sensíveis à ação do Complemento.

No presente estudo a participação das ADAMs na clivagem de MCP e morte celular por Complemento foi também determinada em ensaios na qual células renais foram incubadas com veneno de L. intermedia e tratadas com os inibidores para ADAM 10 e ADAM 17, e da galardina. Os resultados obtidos mostraram que assim como a galardina, tais inibidores preveniram a clivagem de MCP e foram capazes de reduzir, significativamente, a morte celular mediada por complemento. Estudos realizados por Hakulien e Keski-Oja (2006) mostraram que o regulador MCP é susceptível à clivagem por ADAM 10 e que tal evento guarda relação com a ativação de caspases no processo de apoptose em células epiteliais.

A ADAM 17, também conhecida como TACE (TNF- $\alpha$-converting enzyme), tem participação importante em muitas patologias como câncer, doenças vasculares e inflamatórias; também pode inativar receptores ou ativar fatores de crescimento, além de liberar citocinas como TNF- $\alpha$ (KILLAR et al., 1999; ARRIBAS, ESSELENS, 2009, GOOZ, M, 2010). Nas doenças renais crônicas, ADAM 17 está diretamente relacionada ao controle da expressão do receptor EPCR (BELL e GOZZ, 2010) e EGFR envolvidas na insuficiência renal, lesões inflamatórias e fibróticas em camundongos (MELENHORST et al. 2009). No presente estudo utilizando inibidores para ADAM 10 e ADAM 17, mostramos que estes foram capazes de controlar a redução dos marcadores de superfície EPCR, EGFR e $\beta 2$ microglobulina, induzido pelo veneno/ SMase D de Loxosceles, sugerindo a participação destas duas classes de proteases nos danos das células renais. 


\section{CONCLUSÃO}

Em conclusão, os dados apresentados, utilizando células renais humanas, sugerem que metaloproteases de matriz extracelular e da família das adamlisinas estão envolvidas na injúria renal induzida por SMases D do veneno de aranhas Loxosceles. MMP-2 e MMP-9 parecem contribuir para a morte celular sendo o processo ainda mais agravado pela ativação desregulada do sistema complemento, após clivagem de MCP por metaloproteases como ADAM 10 e ADAM 17. O uso de inibidores de metaloproteases, parece ter um efeito protetor sobre o dano causado pelo veneno de Loxosceles às células renais. 


\section{REFERÊNCIAS}

ABBATE, M.; ZOJA, C.; REMUZZI, G. How does proteinuria cause progressive renal damage? J. Am. Nephrol., v. 17, n. 11, p. 2974-2984, 2006.

ARRIBAS, J., ESSELENS, C. ADAM17 as a therapeutic target in multiple diseases. Curr. Pharm. Des., v.5, n.20, p.2319-2335, 2009.

ATKINS, J. A.; WINGO, C. W.; SODEMAN, W. A.; FLYNN, J. E. Necrotic arachnidism. Am. J. Trop. Med. Hyng., v. 7, n.2, p. 165- 184, 1958.

ATKINSON, J. P.; GOODSHIP, T. H. Complement factor $\mathrm{H}$ and the hemolytic uremic syndrome. J. Exp. Med., v. 204, n. 6, p. 1245-1248, 2007.

BAE, J. S.; KIM, I. S.; REZAIE, A. R. Thrombin down-regulates the TGF-beta-mediated synthesis of collagen and fibronectin by human proximal tubule epithelial cells through the EPCR-dependent activation of PAR-1. J. Cell Physiol., v. 225, n. 1, p. 233-239, 2010.

BARILLA-LaBARCA, M. L.; LISZEWSKI, M. K.; LAMBRIS, J. D.; HOURCADE, D.; ATKINSON, J. P. Role of membrane cofactor protein (CD46) in regulation of C4b and C3b deposited on cells. J. Immunol., v. 168, n. 12, p. 6298-6304, 2002.

BARNES, R.D., RUPPERT, E.E. Quelicerados In: Zoologia dos Invertebrados. Ed Roca, $6^{\text {a }}$ ed. São Paulo: Rocca, 1984. p.606-635.

BASILE, D. P.; FREDRICH, K.; WEIHRAUCH, D.; HATTAN, N.; CHILIAN, W. M. Angiostatin and matrix metalloprotease expression following ischemic acute renal failure. Am. J. Physiol. Renal Physiol., v.286, n.5, p. F893-F902, 2004.

BELL, H. L.; GÖÖZ, M. ADAM-17 is activated by the mitogenic protein kinase ERK in a model of kidney fibrosis. Am. J. Med. Sci., v.339, n.2, p.105-7, 2010.

BENNETT, W. M.; ELZINGA, L. W.; PORTER, G. A. Tubulo interstitial diease and toxic nephropaty. In: Brenner, B, Rector, F, editors. The kidney. New York: WB Saunders, 1991, $1941 \mathrm{p}$.

BERGER S. P.; DAHA, M. R. Complement in glomerular injury. Semin. Immunopathol., v. 29, p. 375-384, 2007.

BEXBORN, F.; ANDERSSON, P. O.; CHEN, H.; NILSSON, B.; EKDAHL, K. N. The tickover theory revisited: formation and regulation of the soluble alternative complement $\mathrm{C} 3$ convertase (C3( $\left.\mathrm{H}_{2} \mathrm{O}\right) \mathrm{Bb}$ ). Mol. Immunol., v. 45, n. 8, p. 2370-2379, 2008.

De acordo com:

ASSOCIAÇÃO BRASILEIRA DE NORMAS

TÉCNICAS. NBR 6023: informação e

documentação: referências: elaboração. Rio de

Janeiro, 2002. 
BIANCONE, L.; DAVID, S.; DELLA PIETRA, V.; MONTRUCCHIO, G.; CAMBI, V.; CAMUSSI, G. Alternative pathway activation of complement by cultured human proximal tubular epithelial cells. Kidney Int., v. 45, n. 2, p. 451-60, 1994.

BLACK, S.; KUSHNER, I.; SAMOLS, D. C-reactive protein. J. Biol. Chem., v. 279, p. 48487-48490, 2004.

BLODGETT, A. B.; KOTHINTI, R. K.; KAMYSHKO, I.; PETERING, D. H.; KUMAR, S.; TABATABAI, N. M. A fluorescence method for measurement of glucose transport in kidney cells. Diabetes Technol. Ther., v. 13, n. 7, p. 743-51, 2011.

BLOM, A. M.; VILLOUTREIX, B. O.; DAHLBACK, B. Complement inhibition C4bbinding protein - friend or foe in the innate immune system? Mol. Immunol., v. 40, p. 13331356, 2004.

BÖKENKAMP, A.; LUDWIG, M. Disorders of the renal proximal tubule. Nephron Physiol., v. 118, n. 1, p. 1-6, 2011.

BOTTO, M.; KIRSCHFINK, M.; MACOR, P.; PICKERING, M. C.; WÜRZNER, R.; TEDESCO, F. Complement in human diseases: Lessons from complement deficiencies. Mol. Immunol., v.46, n.14, p.2774-2783, 2009.

BUCHERL, W. Biology and venoms of the most important South American spiders of the genera Phoneutria, Loxosceles, Lycosa and Latrodectus. Am. Zool., v.9, 157-159, 1969.

BUELLI, S.; ABBATE, M.; MORIGI, M.; MOIOLI, D.; ZANCHI, C.; NORIS, M.; ZOJA, C.; PUSEY, C. D.; ZIPFEL, P. F.; REMUZZI, G. Protein load impairs factor H binding promoting complement-dependent dysfunction of proximal tubular cells. Kidney Int., v. 75, n. 10, p. 1050-1059, 2009.

CAMUSSI,G.; ROTUNNO, M.; SEGOLONI, G.; BRENTJENS, J. R.; ANDRES, G. A. In vitro alternative pathway activation of complement by the brush border of proximal tubules of normal rat kidney. J. Immunol., v.128, n.4, p. 1659-1663, 1982.

CAPRIOLI, J.; NORIS, M.; BRIOSCHI, S.; PIANETTI, G.; CASTELLETTI, F.; BETTINAGLIO, P.; MELE, C.; BRESIN, E.; CASSIS, L.; GAMBA, S.; PORRATI, F.; BUCCHIONI, S.; MONTEFERRANTE, G.; FANG, C. J.; LISZEWSKI, M. K.; KAVANAGH, D.; ATKINSON, J. P.; REMUZZI, G. Genetics of HUS: the impact of MCP, $\mathrm{CFH}$, and IF mutations on clinical presentation, response to treatment, and outcome. Blood., v. 108, p.1267-1279, 2006.

CHAIM, O.M.; SADE, Y.B.; DA SILVEIRA, R.B.; TOMA, L.; KALAPOTHAKIS, E.; CHAVEZ-OLÓTEGUI, C.; MANGILI, O. C.; GREMSKI, W.; VON DIETRICH, C. P.; NADER, H. B.; VEIGA, S. S. Brown spider dermonecrotic toxin directly induces nephrotoxicity. Toxicol. Appl. Pharmacol., v.211, n.1, p.64-77, 2006.

CÓRDOBA, S. R.; ESPARZA-GORDILLO, J.; JORGE, E. G.; LOPEZ-TRASCASA, M.; SÁNCHEZ-CORRAL, P. The human complement factor $\mathrm{H}$ : functional roles, genetic variations an disease associations. Mol. Immunol., v. 41, p. 355-367, 2004. 
COX, G.; JONES, J.; D'BYRNE, K. Matrix metalloproteinase-9 and the epidermal growth factor signal pathway in operble non-small cell lung câncer. Clin. Cancer Res., v.6, p. 2349 $2355,2000$.

DAMEN, W. G.; HAUSDORF, M.; SEYFARTH, E. A.; TAUTZ, D. A conserved mode of head segmentation in arthropods revealed by the expression pattern of Hox genes in a spider. Proc. Natl. Acad. Sci USA., v.95, n.18, p.10665-10670, 1998.

DEBAN, L.; BOLTAZZI, B.; GARLANDA, C.; DE LA TORRE, Y.M.; MANTOVANI, A. Pentraxins: Multifunctional proteins at the interface of innate immunity and inflammation. Biofactors., v. 36, n. 2, p. 138-145, 2009.

DE VRIES, B.; MATTHIJSEN, R. A.; WOLFS, T. G.; VAN BIJNEN, A. A.; HEERINGA, P.; BUURMAN, W. A. Inhibition of complement factor C5 protects against renal ischemiareperfusion injury: inhibition of late apoptosis and inflammation. Transplantation., v. 75, n. 3, p. 375-382, 2003.

DILLAHA, C. J.; JANSEN, G.T.; HONEYCUTT, W. M.; HAYDEN, C. R. North American loxoscelism. Necrotic bite of the Brown recluse spider. JAMA., v.188, p. 33-36, 1964.

EDELWEISS, M. I. A.; MEINE, M. H. M; de M., SCROFERNEKER. Importância do sistema complemento em nefrologia. J. Bras. Nefrol., v. 19, n. 1, p. 32-41, 1997.

EDWARDS, D. R.; HANDSLEY, M. M.; PENNINGTON, C. J. The ADAM metalloproteinases. Mol. Aspects Med., v.29, n.5, p.258-89, 2008.

FEARON, D. T.; AUSTEN, K. F. Initiation of C3 cleavage in the alternative complement pathway. J. Immunol., v. 115, n. 5, p. 1357-1361, 1975.

FERNANDES-PEDROSA, M. F.; JUNQUEIRA-DE-AZEVEDO, I. L.; GONÇALVES-DEANDRADE, R. M.; KOBASHI, L. S.; ALMEIDA, D. D.; HO, P. L.; TAMBOURGI, D. V. Transcriptome analysis of Loxosceles laeta (Araneae, Sicariidae) spider venomous gland using expressed sequence tags. BMC Genomics., v. 9, p.279, 2008.

FIJEN, C. A.; VAN DEN BOGAARD, R.; SCHIPPER, M.; MANNENS, M.; SCHLESINGER, M.; NORDIN, F. G.; DANKERT, J.; DAHA, M. R.; SJÖHOLM, A. G.; TRUEDSSON, L.; KUIJPER, E. J. Properdin deficiency: molecular basis and disease association. Mol. Immunol., v.36, n.13-14, p.863-7, 1999.

FISCHER, M. L. Levantamento das espécies do gênero Loxosceles Heinecken \& Lowe, 1832, no município de Curitiba, Paraná, Brasil. Estudos de Biologia, Publicação da Pontifícia Universidade Católica do Paraná, v. 3, n. 38, p. 66-86, 1994.

FRANCIS, K.; VAN BEEK, J.; CANOVA, C.; NEAL, J. W.; GASQUE, P. Innate immunity and brain inflammation: the key role of Complement. Exp. Rev. Mol. Med., v. 5, n. 15, p. 119, 2003.

FUTRELL, J. Loxoscelism. Am. J. Med. Sci., v.304, n.4, p. 261-267, 1992. 
GAARKEUKEN, H.; SIEZENGA, M. A.; ZUIDWIJK, K.; KOOTEN, C. VAN, RABELINK, T. J., DAHA, M. R., BERGER, S. P. Complement activation by tubular cells is mediated by properdin biding. Am. J. Physiol. Renal Physiol., v. 295, p. F1397-F1403, 2008.

GOLUB, L. M.; RAMAMURTHY, N.; MCNAMARA, T. F.; GOMES. B.; WOLFF, M.; CASINO, A.; KAPOOR, A.; ZAMBON, J.; CIANCIO, S.; SCHNER, M. Tetracyclines inhibit tissue collagenase activity. A new mechanism in the treatment of periodontal disease. J. Periodontal Res., v. 19, n.6, p. 651-655, 1984.

GONÇALVES-DE-ANDRADE, R. M.; OLIVEIRA, K. C.; GIUSTI, A. L.; DIAS DA SILVA, W.; TAMBOUGI, D. V. Ontogenetic development of Loxosceles intermedia spider venom. Toxicon., v. 37, n. 4, p. 627-632, 1999.

GÖÖZ, M. ADAM-17: the enzyme that does it all. Crit. Rev. Biochem. Mol. Biol., v.45, n.2, p.146-169, 2010.

GRIVICICH, I.; REGNER, A. DA ROCHA, A. B. Morte celular por apoptose. Rev. Bras. Cancerologia, v.53, n.3, p.335-343, 2007.

HARRIS, C.L., PETTIGREW, D.M., LEA, S.M., MORGAN, B.P. Decay-accelerating factor must bind both components of the complement alternative pathway $\mathrm{C} 3$ convertase to mediate efficient decay. J. Immunol., v. 178, n. 1, p. 352-359, 2007.

HAKULINEN J; KESKI-OJA J. ADAM10-mediated release of complement membrane cofactor protein during apoptosis of epithelial cells. J. Biol. Chem., v.281, n.30, p.2136921376, 2006.

HE, C.; IMAI, M.; SONG, H.; QUIGG, R. J.; TOMLINSON, S. Complement inhibitors targeted to the proximal tubule prevent injury in experimental nephritic syndrome and demonstrate a key role for C5b-9. J. Immunol., v. 174, n. 9, p. 5750-5757, 2005.

HERBST, R. S. Review of epidermal growth factor receptor biology. Int. J. Radiat. Oncol. Biol. Phys., v. 59, p. 21-26, 2004.

HOGAN, C. J., BÁRBARO, K. C., WINKEL, K. Loxoscelism: old obstacles, new directions. Ann. Emerg. Med., v. 44, p. 608- 624, 2004.

JANG, H. R.; RABB, H. The innate response in ischemic acute kidney injury. Clin. Immunol., v. 130, n. 1, p. 41-50, 2009.

JEVNIKAR, A. M.; WUTHRICH, R. P.; BRENNAN, D. C.; MASLINSKI, W.; GLIMCHER, L. H.; RUBIN-KELLEY, V. E. TNF-alpha is expressed on the surface of kidney proximal tubular cells. Transplant Proc., v. 23, p. 231-232, 1991.

JI, X.; AUMI, K.; SASAKI, M.; NONAKA, M. Ancient origin of the complement lectin pathway revealed by molecular cloning of mannan binding protein-associated serine protease from a urochordate, the Japanese ascidian Halocynthia roretzi. Proc. Natl. Acad. Sci USA., v. 94, n.12, p.6340-6345, 1997. 
JÓZSI, M.; ZIPFEL, P. F. Factor H family proteins and human diseases. Trends Immunol., v. 29, n. 8 , p. $380-387,2008$.

KEMPER, C.; ATKINSON, J. P. T-cell regulation: with complement from innate immunity. Nat. Rev. Immunol., v. 7, p. 9-18, 2007.

KILLAR, L.; WHITE, J.; BLACK, R.; PESCHON, J. Adamalysins. A family of metzincins including TNF-alpha converting enzyme (TACE). Ann. N. Y. Acad. Sci., v.30, n.878, p.442452, 1999.

KIM, D. D.; SONG, W. C. Membrane complement regulatory proteins. Clin. Immunol., v. 118, p. 127-136, 2006.

KING JR, L. E.; REES, R. S. Dapsone treatment of a brown recluse bite. JAMA, v.250, n.5, p.648, 1983.

KLEINER, D. E.; STETLER-STEVENSON, W. G. Quantitative zymography: detection of picogram quantities of gelatinases. Anal. Biochem., v. 218, n. 2, p. 325-329, 1994.

KÖHL, J. The role of complement in danger sensing and transmission. Immunol. Res., v. 34, n. 2, p. 157-176, 2006.

KOIDE, H.; NAKAMURA, T.; EBIHARA, I.; TOMINO, Y. Increase mRNA expression of metalloproteinase-9 in peripheral-blood monocytes from patients with immunoglobulin A nephropathy. Am. J. Kidney Dis., v. 28, p. 32- 39, 1996.

KRYCH-GOLDBERG, M.; HAUBART, R. E.; SUBRAMANIAN, V. B.; YURCISIN II, B. M.; CRIMMINS, D. L.; HOURCADE, D. E.; ATKINSON, J. P. Decay accelerating activity of complement receptor type I (CD35). J. Biol. Chem., v. 274, n. 44, p. 31160-31168, 1999.

KUSMA, J.; CHAIM, O. M.; WILLE, A. C.; FERRER, V. P.; SADE, Y. B.; DONATTI, L.; GREMSKI, W.; MANGILI, O. C.; VEIGA, S. S. Nephrotoxicity caused of brown spider venom phospholipase D (dermonecrotic toxin) depends on catalytic activity. Biochimie., v. 90, n. 11-12, p. 1722-1736, 2008.

LAEMMLI, U. K. Cleavage of structural proteins during the assembly of the head of bacteriophage T4. Nature, v. 227, p. 680-685, 1970.

LEE, B. H.; KWAK, S. H.; SHIN, J. I.; LEE, S. H.; CHOI, H. J.; KANG, H. G.; HA, I. S.; LEE, J. S.; DRAGON-DUREY, M. A.; CHOI, Y.; CHEONG, H. I. Atypical hemolytic uremic syndrome associated with complement factor $\mathrm{H}$ autoantibodies and CFHR1/CFHR3 deficiency. Pediatr. Res., v. 66, n. 3, p. 336-340, 2009.

LEEHEY, D. J.; SONG, R. H.; ALAVI, N.; SINGH, A. K. Decreased degradative enzymes in mesangial cells cultured in high glucose media. Diabetes, v. 44, p. 929-935, 1995.

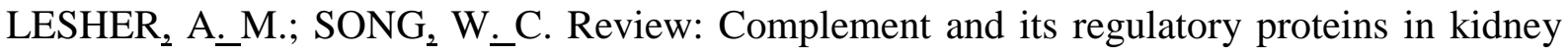
diseases. Nephrology (Carlton). v.15, n.7, p.663-675, 2010. 
LIN, F.; SALANT, D. J.; MEYERSON, H.; EMANCIPATOR, S.; MORGAN, B. P; MEDOF, M. E. Respective roles of decay-accelerating factor and CD59 in circumventing glomerular injury in acute nephrotoxic serum nephritis. J. Immunol., v. 172, n.4, p. 26362642, 2004.

LIU, Q. A.; HENGARTNER, M. O. The molecular mechanism of programmed cell death in C. elegans. Ann. N. Y. Acad. Sci., v.887, p.92-104, 1999.

LOWRY, O. H.; ROSEBROUGH, N. J.; FARR, A. L.; RANDALL, R. J. Protein measurement with the Folin phenol reagent. J. Biol. Chem., v. 193, n. 1, p. 265-275, 1951.

LUCAS, S. Spiders in Brazil. Toxicon, v.26, n.9, p. 759- 775, 1988.

LUCATO JR, R. V.; ABDULKADER, R. C.; BARBARO, K. C.; MENDES, G. E.; CASTRO, I.; BAPTISTA, M. A.; CURY, P. M.; MALHEIROS, D. M.; SCHOR, N.; YU, L.; BURDMANN, E. A. Loxosceles gaucho venom-induced acute kidney injury - in vivo and in vitro studies. PLoS Negl. Trop. Dis., v.5, n.5, p.1-5, 2011.

LUCIANO, M. N.; SILVA, P. H.; CHAIM, O. M.; DOS SANTOS, V. L. P.; FRANCO, C. R. C.; SOARES, M. F. S.; ZANATA, S. M.; MANGILI, O. C; GREMSKI,W.; VEIGA, S. S. Experimental evidence for a direct cytotoxicity of Loxosceles intermedia (brown spider) venom in renal tissue. J. Histochem. Cytochem., v.52, n.4, p. 455-467, 2004.

LUNG, J. M.; MALLORY, S. B. A child with spider bite and glomerulonephritis: a diagnostic challenge. Int. J. Dermat., v. 39, p. 287-289, 2000.

MALAQUE, C. M. S; CASTRO-VALENCIA, J. E.; CARDOSO, J. L. C.; FRANÇA, F. O. S; BÁRBARO, K. C; FAN, H. W. Clinical and epidemiological features of definitive and presumed loxoscelism in São Paulo, Brazil. Rev. Int. Med. Trop. S. Paulo., v. 44, n.3, p. 139-143, 2002.

MALHOTRA, K. K; CHADHA, J. S.; MIRDEHGAN, M., TANDON, H. D. Acute renal failure following scorpion sting. Am.J. Trop. Med Hyg., v. 27, p. 623-626, 1978.

MANZONI-DE-ALMEIDA, D.; FERNANDES-PEDROSA, M. DE F.; GONÇALVES-DEANDRADE, R. M.; MARCELINO, J. R.; GONDO-HIGASHI, H.; DE AZEVEDO, I.; HO, P. L.; VAN DEN BERG, C. W.; TAMBOURGI, D. V. A new anti-loxoscelic serum produced against recombinant sphingomyelinase D: results of preclinical trials. Am. J. Trop. Med Hyg., v. 79, n. 3, p. 463-470, 2008.

McMILLAN, J. I.; RIORDAN, J. W.; COUSER, W. G.; POLLOCK, A. S.; LOVETT, D. H. Characterization of a glomerular epitheial cell metalloproteinase as matriz metalloproteinase9 with enhanced expression in a model of membranous nephropathy. J. Clin. Invest., v. 97, n. 4, p. $1095-1101,1996$.

MEIER, P.; FINCH, A.; EVAN, G. Apoptosis in development. Nature, v. 407, p.796-801, 2000. 
MELENHORST, W. B.; VISSER, L.; TIMMER, A.; VAN DEN HEUVEL, M. C.; STEGEMAN, C. A.; VAN GOOR, H. ADAM17 upregulation in human renal disease: a role in modulating TGF-alpha availability? Am. J. Physiol. Renal Physiol., v. 297, n. 3, p. F781F790, 2009.

MIHLAN, M.; HEBECKER, M.; DAHSE, H. M.; HÄLBICH, S.; HUBER-LANG, M.; DAHSED, R.; ZIPFEL, P. F.; JÓZSI, M. Human complement factor H-related protein 4 binds and recruits native pentameric C-reactive protein to necrotic cells. Mol. Immunol., v. 46, p. 335-344, 2009.

MINISTÉRIO DA SAÚDE. Manual de diagnósticos e acidentes por animais peçonhentos. Local: Brasilia. Fundação Nacional da Saúde, 2001.29p.

MOLLER-KRISTENSEN, M.; WANG, W.; RUSEVA, M.; THIEL, S.; NIELSEN, S.; TAKAHASHI, K.; SHI, L.; EZEKOWITZ, A.; JENSENIUS, J. C.; GADJEVA, M. Mannanbinding lectin recognizes structures on ischaemic reperfused mouse kidneys and is implicated in tissue injury. J. Immunol., v. 61, n. 5, p. 426-434, 2005.

MORGAN, B. P. Regulation of the complement membrane attack pathway. Crit. Rev. Immunol., v. 19, n. 3, p. 173-198, 1999.

MORGAN, B. P.; HARRYS, C. L. Complement therapeutics; history and current progress. Mol. Immunol., v.40, n.2-4, p.159-170, 2003.

MORITA, Y.; IKEGUCHI, H.; NAKAMURA, J.; HOTTA, N.; YUZAWA, Y.; MATSUO, S. Complement activation products in the urine from proteinuric patients. J. Am. Soc. Nephrol., v. 11, n. 4, p. 700-707, 2000.

MORRISSEY, J. H. Silver stain for proteins in polyacrylamide gels: a modified procedure with enhanced uniform sensitivity. Anal. Biochem., v.117, p.307-310, 1980.

MURPHY, G.; STANTON, H.; COWELL, S.; BUTLER, G.; KNÄUPER, V.; ATKINSON, S.; GAVRILOVIC, J. Mechanism for pro matrix metalloproteinase activation. APMIS., v. 107, n. 1, p. 38-44, 1999.

NAÍNI, A. E.; HARANDI, A. A.; MOGHTADERI, J.; BASTANI, B.; AMIRAN, A. Doxycycline: a pilot study to reduce diabetic proteinuria. Am. J. Nephrol., v. 27, p. 269 273, 2007.

NANGAKU, M. Complement regulatory proteins in glomerular diseases. Kidney Int., v.54, n.6, p. 1934-1944, 1998.

NAGAKU, M.; PIPPIN, J.; COUSER, W. G. Complement membrane attack complex (C5b-9) mediates intersticial diease in experimental nephrotic syndrome. J. Am. Soc. Nephrol., v.10, p. 2323-2331, 1999.

NAGAKU, M.; PIPPIN, J.; COUSER, W. G. C6 mediates chronic progression of tubulointerstitial damage in rats with remnat kidneys. J. Am. Soc. Nephrol., v. 13, p. 928936, 2002. 
NG, P. M. P.; LeSAUX, A.; LI, C. M.; TAN, N. S.; LU, J.; THIEL, S.; HO, B.; DING, J. L. C-reactive protein collaborates with plasma lectins to boost immune response against bacteria. EMBO J., v. 26, n. 14, p. 3431-3440, 2007.

OLIVEIRA, K. C; GONÇALVES DE ANDRADE, R. M.; GIUSTI, A. L.; SILVA, W. D; TAMBOURGI, D. V. Sex-linked variation of Loxosceles intermedia spider venoms. Toxicon, v. 37, p.217-221, 1999.

OLIVEIRA, K. C.; GONÇALVES-DE-ANDRADE, R. M.; PIAZZA, R. M.; FERREIRA JR, J. M.; VAN DEN BERG, C. W.; TAMBOURGI, D. V. Variations in Loxosceles spider venom composition and toxicity contribute to the severity of envenomation. Toxicon, v. 45, n. 4, p. 421-429, 2005.

PAIXÃO-CAVALCANTE, D.; VAN DEN BERG, C. W.; DE FREITAS FERNANDESPEDROSA, M.; GONCALVES DE ANDRADE, R. M.; TAMBOURGI, D. V. Role of matriz metalloproteinases in HaCat keratinocytes apoptosis induced by Loxosceles venom sphingomyelinase D. J. Invest. Dermatol., v.126, n.1, p. 61- 68, 2006.

PAIXÃO-CAVALCANTE, D.; VAN DEN BERG, C. W.; GONÇALVES-DE-ANDRADE, R. M.; FERNANDES-PEDROSA, M. F.; OKAMOTO, C. K.; TAMBOURGI, D. V. Tetracycline protects against dermonecrosis induced by Loxosceles spider venom. J. Invest. Dermatol., v.127, n.6, p.1410-1418, 2007.

PANCHAPAKESAN, U.; POLLOCK, C.; SAAD, S. Review article: importance of the kidney proximal tubular cells in thiazolidinedione-mediated sodium and water uptake. Nephrology, v. 14, n. 3, p. 298-301, 2009.

PECHMANN, M.; KHADJED, S.; SPRENGER, F.; PRPIC, N. M. Patterning mechanisms and morphological diversity of spider appendages and their importance for spider evolution. Arthropod Struct., v.39, n.6, p.453-467, 2010.

PEPYS, M. B.; HIRSCHFIELD, G. M. C-reactive protein: a critical update. J. Clin. Invest., v. 111, n. 12, p. 1805-1812, 2003.

PICKERING, M. C.; DE JORGE, E. G.; MARTINEZ-BARRICARTE, R.; RECALDE, S.; GARCIA-LAYANA, A.; ROSE, K. L.; MOSS, J.; WALPORT, M. J.; COOK, H. T.; DE CÓRDOBA, S. R.; BOTTO, M. Spontaneous hemolytic uremic syndrome triggered by complement factor H lacking surface recognition domains. J. Exp. Med., v. 204, n. 6, p. 1249-1256, 2007.

PLATNICK, N. I. The world spider catalog, version 8.0. American Museum of Natural History, 2011, online at http://research.amnh.org/entomology/spiders/catalog/index.html

PRETEL, F.; GONÇALVES DE ANDRADE, R. M.; MAGNOLI, F. C.; DILVA, M. E. R.; FERREIRA JR, J. M. F.; VAN DEN BERG, C. W.; TAMBOURGI, D. V. Analysis of the toxic potential of venom from Loxosceles adelaida, a Brazilian Brown spider from karstic areas. Toxicon, v. 45, p. 449-458, 2005.

PRITCHARD, J. B.; MILLER, D. S. Renal secretion of organic anions and cations. Kidney Int., v. 49, n.6, p.1649-1654, 1996. 
REES, R. S; SHACK, R. B.; WITHERS, E.; MADDEN, J.; FRANKLIN, J.; LYNCH, J. B. Management of the brown recluse spider bite. Plast. Reconstr. Surg., v.68, n.5, p. 768-773, 1981.

REES, R. S.; O'LEARY, J. P.; KING JR, L. E. The pathogenesis of systemic loxoscelism following brown recluse spider bites. J. Surg. Res., v.35, n.1, p. 1-10, 1983.

REID, K. B., PORTER, R. R. The proteolytic activation systems of complement. Ann. Rev. Biochem., v.50, p.433-64, 1981.

RIBEIRO, L. A.; EICKSTEDT, V. R. D.; RÚBIO, G. B. G.; KONALSAISEN, J. F.; HANDAR, Z.; ENTRES, M.; CAMPOS, V. A. F. P.; JORGE, M. T. Epidemiologia do acidente por aranhas do gênero Loxosceles Heinecken and Lowe no estado do Paraná (Brasil). Mem. Int. Butantan, v.55, n.1, p. 19- 26, 1993.

RIBEIRO, R. O; CHAIM, O. M.; DA SILVEIRA, R. B.; GREMSKI, L. H.; SADE, Y. B.; PALUDO, K. S.; SENFF'RIBEIRO, A.; DE MOURA, J.; CHÁVEZ-OLÓRTEGUI, C.; GREMSKI, W.; NADER, H. B.; VEIGA, S. S. Biological e structural comparison of recombinant phospholipase D toxins from Loxosceles intermedia (brown spider) venom. Toxicon, v. 50, n.8, p. 1162-1174, 2007.

ROSEN, F. S.; DAVIS III, A. E. Deficiences of C1 inhibitor. Best Pract. Res. Clin. Gastroenterol., v. 19, n. 2, p. 251-261, 2005.

ROVIN, B. H.; PHAN, L. T. Chemotactic factors and renal inflammation. Am. J. Kidney Dis., v. 31, n. 6, p.1065-84, 1998.

RUDDY, S.; AUSTEN, K. F. Activation of the complement and properdin systems in rheumatoid arthritis. Ann. N.Y Acad. Sci., v.256, p.96-104, 1975.

RUSSEL, F. E.; WALDRON, W. G.; MADON, M. B. Bites by the brown spiders Loxosceles unicolor and Loxosceles arizonica in California and Arizona. Toxicon, v.7, p. 109-117, 1969.

RUNZA, V. L.; SCHWAEBLE, W.; MÄNNEL, D. N. Ficolins: novel pattern recognition molecules of the innate immune response. Immunobiology, v.213, n.3-4, p.297-306, 2008.

RYAN, M. J.; JOHNSON, G.; KIRK, J.; FUERSTENBERG, S. M.; ZAGER, R. A.; TOROKSTORB, B. HK-2: An immortalized proximal tubule epithelial cell line from normal adult human kidney. Kidney Int., v.45, p. 48-57, 1994.

SEALS, D. S.; COURTNEIDGE, S. A. The ADAMs family of metalloproteases: multidomain proteins with multiple functions, Genes Dev., v. 17, p. 7-30, 2003.

SCHEJBEL, L.; ROSENFELDT, V.; MARQUART, H.; VALERIUS, N. H.; GARRED, P. Properdin deficiency associated with recurrent otitis media and pneumonia, and identification of male carrier with Klinefelter syndrome. Clin. Immunol., v.131, n.3, p.456-462, 2009.

SCHENONE, H. Cutaneous loxoscelism with edematous predominance. Bol. Chil. Parasitol., v. 53, p.78-83, 1998. 
SECRETARIA DE VIGILÂNCIA EM SAÚDE. ACIDENTES POR ANIMAIS PEÇONHENTOS. 2007. In: Ministério da Saúde (BR). Disponível em: http://portal.saude.gov.br/portal/saude. Acesso em:18/01/2012.

SHEERIN, N. S.; RISLEY, P.; ABE, K.; TANG, Z.; WONG, W.; LIN, T.; SACKS, S. H. Synthesis of complement protein C3 in the kidney is an important mediator of local tissue injury. FASEB J., v. 22, n. 4, p. 1065-1072, 2008.

SHOJI, T.; NAKANISHI, I.; KUNITOU, K.; TSUBAKIHARA, Y.; HIROOKA, Y.; KISHI, Y.; HATANAKA, M.; MATSUMOTO, M.; TOYOSHIMA, K.; SEYA, T. Urine levels of CD46 (Membrane Cofactor Protein) are increased in patients with glomerular diseases. Clin. Immunol., v. 95, n. 2, p. 163-169, 2000.

SIEZENGA, M. A., VAN DER GEEST, R. N.; MALLAT, M. J.; RABELINK, T. J.; DAHA, M. R.; BERGER, S. P. Urinary properdin excretion is associated with intrarenal complement activation and poor renal function. Nephrol. Dial. Transplant., v.25, n.4, p.1157-1160, 2009.

SILVA, P. H.; SILVEIRA, R. B.; APPEL, M. H.; MANGILINI, O. C.; GREMSKI, W.; VEIGA, S. S. Brown spiders and loxoscelism. Review. Toxicon, v.44, p.693-709, 2004.

SISTEMA DE INFORMAÇÃO DE AGRAVOS DE NOTIFICAÇÃO (SINAN). In: Ministério da Saúde (BR). 2012. Disponível em: http://portal.saude.gov.br/portal/saude. Acesso em: 18/01/2012.

SJÖBERG, A. P.; TROUW, L. A.; CLARK, S. J.; SJOLANDER, J.; HEINEGARD, D.; SIM, R. B.; DAY, A. J.; BLOM, A. M. The factor $\mathrm{H}$ variant associated with age-related macular degeneration (H384) and the non-disease associated form bind differentially to C-reactive protein, fibromodulin, DNA and necrotic cells. J. Biol. Chem., v. 282, p. 10894-10900, 2007.

SJÖBERG, A. P.; TROUW, L. A.; BLOM, A. M. Complement activation and inhibition: a delicate balance. Trends in Immunol., v. 30, n. 2, p. 83-90, 2009.

STAHL, P. D.; EZEKOWITZ, R. A. The mannose receptor is a pattern recognition receptor involved in host defense. Curr. Opin. Immunol., v.10, n.1, p.50-55, 1998.

STAMENKOVIC, I. Extracellular matrix remodelling: the role of matrix metalloproteinases. J. Pathol., v.200, p.448-464, 2003.

STOVER, C. M.; LUCKETT, J. C.; ECHTENACHER, B.; DUPONT, A.; FIGGITT, S. E; BROWN, J.; MÄNNEL, D. N.; SCHWAEBLE, W. J. Properdin plays a protective role in polymicrobial septic peritonitis. J. Immunol., v.180, n.5, p.3313-3318, 2008.

STRAIN, G. M.; SNIDER, T. G.; TEDFORD, B. L.; COHN, G. H. hyperbaric oxygen effectes on brown recluse spider (Loxosceles reclusa) envenomation in rabbits. Toxicon, v. 29, n.8, p. 989- 996, 1991.

SUNDERKÖTTER, C.; SEELIGER, S.; SCHONLAU, F.; ROTH, J.; HALLMANN, R.; LUGER, T. A.; SORG, C.; KOLDE, G. Different pathways leading to cutaneous leukocytoclastic vasculitis in mice. Exp. Dermatol., v.10, n.6, p.391-404, 2001. 
SUNYER, J. O.; LAMBRIS, J. D. Evolution and diversity of the complement system of poikilothermic vertebrates. Immunol. Rev., v.166, p.39-57, 1998.

TALLANT, C.; MARRERO, A.; GOMIS-RÜTH, F. X. Matrix metalloproteinases: fold and function of their catalytic domains. Biochim. Biophys. Acta., v.1803, n.1, p.20-28, 2009.

TAMBOURGI, D. V.; MAGNOLI, F. C., VON EICKSTEDT, V. R. D.; BENEDETTI, Z. C.; PETRICEVICH, V. L.; DA SILVA, W. D. Incorporation of a $35 \mathrm{kDa}$ purified protein from Loxosceles intermedia spider venom transforms human erythrocytes into activators of autologous complement alternative pathway. J. Immunol., v.155, p.4459-4466, 1995.

TAMBOURGI, D. V.; PETRICEVICH, V. L.; MAGNOLI, F. C.; ASSAF, S. L. M. R.; JANCAR, S.; DIAS DA SILVA, W. Endotoxemic- like shock induced by Loxosceles spider venoms: pathological changes and putative cytokine mediators. Toxicon, v.36, n.2, p. 391403, 1998a.

TAMBOURGI, D. V.; MAGNOLI, F. C.; VAN DEN BERG, C. W.; MORGAN, B. P.; DE ARAÚJO, P. S.; ALVES, E. W.; DA SILVA, W. D. Sphingomyelinases in the venom of the spider Loxosceles intermedia are responsible for both dermonecrosis and complementdependent hemolysis. Biochem. Biophys. Res. Commun. n. 251, p. 366-373, 1998b.

TAMBOURGI, D. V.; MORGAN, B. P.; DE ANDRADE, R. M.; MAGNOLI, F. C.; VAN DEN BERG, C. W. Loxosceles intermedia spider envenomation induces activation of an endogenous metalloproteinase, resulting in cleavage of glycophorins from de erythrocyte surface facilitating complement-mediated lysis. Blood, v.95, n.2, p.683-691, 2000.

TAMBOURGI, D. V.; DE SOUSA DA SILVA, M.; BILLINGTON, S. J.; GONCALVES DE ANDRADE, R. M.; MAGNOLI, F. C.; SONGER, J. G.; VAN DEN BERG, C. W. Mechanism of induction of complement susceptibility of erythrocytes by spider and bacterial sphingolmyelinases. Immunology, v.107, n.1, p.93-101, 2002.

TAMBOURGI, D. V.; FERNANDES- PEDROSA, M. F.; VAN DEN BERG, C. W.; GONÇALVES-DE-ANDRADE, R. M.; FERRACINI, M.; PAIXÃO-CAVALCANTE, D.; MORGAN, B. P.; RUSHMERE, N. K. Molecular Cloning, expression, function and immunoreactivities of members of a gene family of sphingomyelinases from Loxosceles venom glands. Mol. Immunol., v.41, p. 831- 840, 2004.

TAMBOURGI, D. V.; PAIXÃO- CAVALCANTE, D.; GONÇALVES DE ANDRADE, R. M.; FERNANDES PEDROSA, M. F.; MAGNOLI, F. C.; MORGAN, B. P.; VAN DEN BERG, C. W. Loxosceles sphingomyelinase induces Complement- dependent dermonecrosis, neutrophil infiltration and endogenous gelatinase expression. J. Invest. Dermatol., v. 124, p. 725- 731, 2005.

TAMBOURGI, D. V.; FERNANDES-PEDROSA, M. F.; GONÇALVES-DE-ANDRADE, R. M.; BILLINGTON, S. J.; GRIFFITHS, M.; VAN DEN BERG, C. W. Sphingomyelinases D induce direct association of $\mathrm{C} 1 \mathrm{q}$ to the erythrocyte membrane causing complement mediated autologous haemolysis. Mol. Immunol., v. 44, n. 4, p. 576-582, 2007. 
TAMBOURGI, D. V.; GONÇALVES-DE-ANDRADE, R. M.; VAN DEN BERG, C. W. Loxoscelism: From basic research to the proposal of new therapies. Toxicon, v. 56, n. 7, p. 1113-1119, 2010.

TAVARES, F. L.; SOUSA-E-SILVA, M. C. C.; SANTORO, M. L.; BARBARO, K. C.; REBECCHI, I. M. M.; SANO-MARTINS, I. S. Changes in hematologycal, hemostatic and biochemical parameters induced experimentally in rabbits by Loxoxceles gaucho venom. Hum. Exp. Toxicol., v. 23, p.477-486, 2004.

THIEL, S.; GADJEVA, M. Humoral pattern recognition molecules: mannan-binding lectin and ficolins. Adv. Exp. Med. Biol. n .653, p. 58-73, 2009.

THURMAN, J. M.; LJUBANOVIĆ, D.; ROYER, P. A.; KRAUS, D. M.; MOLINA, H.; BARRY, N. P.; PROCTOR, G.; LEVI, M.; HOLERS, V. M. Altered renal tubular expression of the complement inhibitor Crry permits complement activation after ischemia/reperfusion. J. Clin. Invest., v. 116, n. 2, p. 357-368, 2006.

TOKUMURA, A.; KANAYA, Y.; MIYAKE, M.; YAMANO, S.; IRAHARA, M.; FUKUZAWA, K. Increased production of bioative lysophosphatidic acid by serum lysophospholipase D in human pregnancy. Biol. Reprod. v. 67, n.5, p. 1386-1392, 2002.

TOWBIN, H.; STAEHELIN, T.; GORDON, J. Eletrophoretic transfer of proteins from acrylamide gels to nitrocellulose sheets: procedure and some applications. Proc. Natl Acad. Sci. U.S.A., v.76, p.4350-4354, 1979.

TURNBERG, D.; BOTTO, M.; WARREN, J.; MORGAN, B. P.; WALPORT, M. J.; COOK, H. T. CD59 deficiency exacerbates accelerated nephrotoxic nephritis in mice. J. Am. Soc. Nephrol., v. 14, p. 2271-2279, 2003.

UNSWORTH, D. J. Complement deficiency and disease. J. Clin. Pathol., v. 61, p. 10131017, 2008.

VAN DEN BERG, C. W.; DE ANDRADE, R. M.; MAGNOLI, F. C.; MARCHBANK, K. J.; TAMBOURGI, D. V. Loxosceles spider venom induces metalloproteinase mediated cleavage of MCP/CD46 and MHCI and induces protection against C-mediated lysis. Immunology, v. 107, n. 1, p.102-10, 2002.

VAN DER POL, P.; ROOS, A.; BERGER, S. P.; DAHA, M. R.; VAN KOOTEN, C. Natural IgM antibodies are involved in the activation of complement by hypoxic human tubular cells. Am. J. Physiol. Renal. Physiol., v.300, n.4, P. F932-F940, 2011.

VAN KOOTEN, C.; DAHA, M. R.; VAN ES, L. A. Tubular epithelial cells: A critical cell type in the regulation of renal inflammatory processes. Exp. Nephrol., v. 7, n. 5-6, p. 429$437,1999$.

VETTER, R. S.; VISSCHER, P. K. Bites and stings of medically important venomous arthropods. Int. J. Dermatol., v. 37, p. 481-496, 1998. 
VOLANAKIS, J.E. Complement-induced solubilization of C-reactive protein-pneumococcal C-polysaccharide precipitates: evidence for covalent binding of complement proteins to $\mathrm{C}$ reactive protein and to pneumococcal C-polysaccharide. J. Immunol., v. 128, n. 6, p. 2745$2750,1982$.

VORUP-JENSEN, T.; PETERSEN, S. V.; HANSEN, A. G.; POULSEN, K.; SCHWAEBLE, W.; SIM, R. B.; REID, K. B.; DAVIS, S. J.; THIEL, S.; JENSENIUS, J. C. Distinct pathways of mannan-binding lectin (MBL)- and $\mathrm{C} 1$-complex autoactivation revealed by reconstitution of MBL with recombinant MBL-associated serine protease-2. J. Immunol., v. 165, n. 4, p. 2093-2100, 2000.

XUE, M.; CAMPBELL, D.; JACKSON, C. J. Protein C is an autocrine growth factor for human skin keratinocytes. J. Biol. Chem., v. 282, n. 18, p. 13610-13616, 2007.

YEE, J. Plasma matrix metalloproteinase-9 and diabetic microalbuminuria: tip of the iceberg? Am. J. Kidney Dis., v.32, p.669-671, 1998.

WALPORT, M. J. Complement. First of two parts. N. Engl. J. Med., v. 344, p. 1058-1066, 2001.

WASSERMAN, G. S.; ANDERSON, D. O. Loxoscelism and necrotic arachnidism. J. Toxicol. Clin. Toxicol., v. 21, p. 451- 455, 1984.

WHITE, M. ADAMs: modulators of cell-cell and cell-matrix interactions. Curr. Opin. Cell. Biol., v. 15, p. 598-606, 2003.

WRIGHT, S. H.; DANTZLER, W. H. Molecular and cellular physiology of renal organic cation and anion transport. Physiol Rev., v. 84, n. 3, p. 987-1049, 2004.

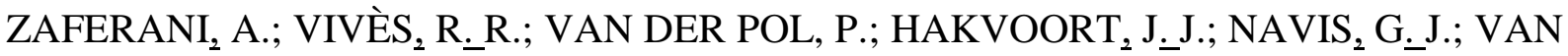
$\mathrm{GOOR}_{2}$ H.; DAHA, M._R.; LORTAT-JACOB, H.; SEELEN, M._A.; VAN DER BORN, J. Identification of tubular heparan sulfate as a docking platform for the alternative complement component properdin in proteinuric renal disease. J. Biol. Chem., v.286, n.7, p.5359-5367, 2011.

ZARKADIS, I. K.; MASTELlOS, D.; LAMBRIS, J. D. Phylogenetic aspects of the complement system. Dev. Comp. Immunol., v.25, n.8-9, p.745-762, 2001.

ZHANG, X. L.; ALI, M. A. Ficolins: structure, function and associated diseases. Adv. Exp. Med. Biol., v.632, p.105-15, 2008.

ZHOU, W.; FARRAR, C. A.; ABE, K.; PRATT, J. R,; MARSH, J. E.; WANG, Y.; STAHL, G. L.; SACKS, S. H. Predominant role for C5b-9 in renal ischemia/reperfusion injury. J. Clin. Invest., v. 105, n. 10, p. 1363-1371, 2000.

ZIPFEL, P. F.; HELLWAGE, J.; FRIESE, M. A.; HEGASY, G.; JOKIRANTA, S. T.; MERI, $\mathrm{S}$. Factor $\mathrm{H}$ and disease: a complement regulator affects vital body functions. Mol. Immunol., v. 36, n. 4-5, p. 241-248, 1999. 
ZIVKOVIC, B. Physiology: coordinated response. Scientific American. 2011. Disponível em: $\quad$ http://blogs.scientificamerican.com/a-blog-around-the-clock/2011/11/19/bio101physiology- coordinated-response/. Acesso em: 18/01/2012. 
